\title{
Bone grafts and bone substitutes for treating distal radial fractures in adults (Review)
}

\author{
Handoll HHG, Watts AC
}

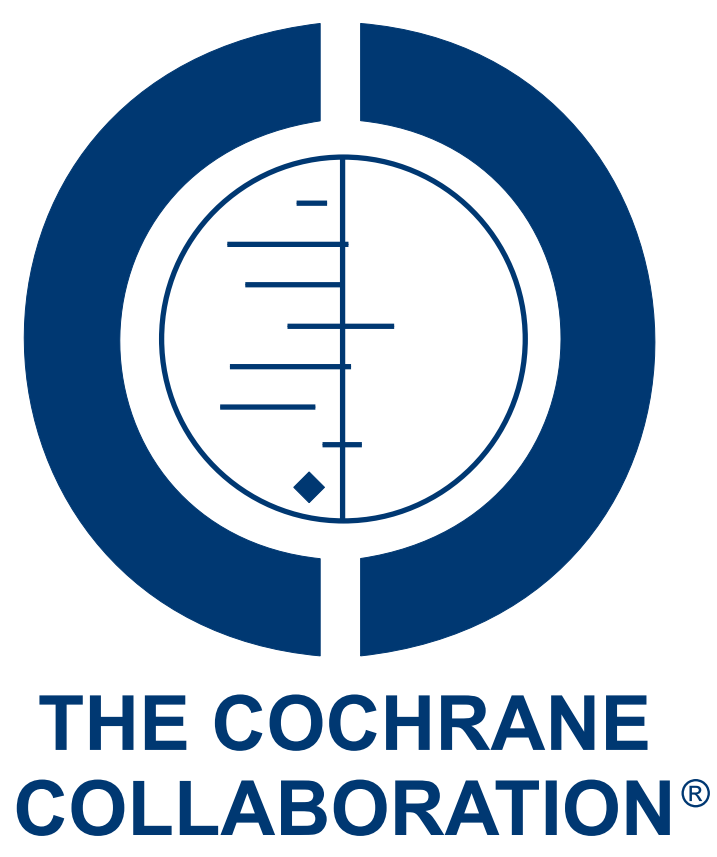

This is a reprint of a Cochrane review, prepared and maintained by The Cochrane Collaboration and published in The Cochrane Library 2009, Issue 3

http://www.thecochranelibrary.com

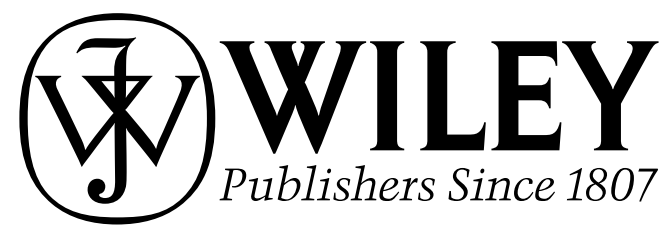

Bone grafts and bone substitutes for treating distal radial fractures in adults (Review)

Copyright $\odot 2009$ The Cochrane Collaboration. Published by John Wiley \& Sons, Ltd. 
TABLE OF CONTENTS

HEADER . . . . . . . . . . . . . . . . . . . . . . . . . . . . . . . . 1

ABSTRACT . . . . . . . . . . . . . . . . . . . . . . . . . . . . . . . . . . . . . . . . . . . . . . . . .

PLAIN LANGUAGE SUMMARY . . . . . . . . . . . . . . . . . . . . . . . . . . . . . . . . . . . . . 2

BACKGROUND . . . . . . . . . . . . . . . . . . . . . . . . . . . . . . . . . . . . . 3

OBJECTIVES . . . . . . . . . . . . . . . . . . . . . . . . . . . . . . . . . . . . . . . 5

METHODS . . . . . . . . . . . . . . . . . . . . . . . . . . . . . . . . . 6

RESULTS . . . . . . . . . . . . . . . . . . . . . . . . . . . . . . . . . . . . . . . . . 12

DISCUSSION . . . . . . . . . . . . . . . . . . . . . . . . . . . . . . . . . . . . . 23

AUTHORS' CONCLUSIONS . . . . . . . . . . . . . . . . . . . . . . . . . . . . . . . . . 28

ACKNOWLEDGEMENTS . . . . . . . . . . . . . . . . . . . . . . . . . . . . . . . . 28

REFERENCES . . . . . . . . . . . . . . . . . . . . . . . . . . . . . . . . . . . . . . . . . . 28

CHARACTERISTICS OF STUDIES . . . . . . . . . . . . . . . . . . . . . . . . . . . . . . . . . . . . . . 31

DATA AND ANALYSES . . . . . . . . . . . . . . . . . . . . . . . . . . . . . . . . . . . . . . 45

Analysis 1.1. Comparison 1 Bone scaffolding (graft/substitute) versus plaster cast, Outcome 1 Functional gradings. .52

Analysis 1.2. Comparison 1 Bone scaffolding (graft/substitute) versus plaster cast, Outcome 2 Non recovery of full grip strength.

Analysis 1.3. Comparison 1 Bone scaffolding (graft/substitute) versus plaster cast, Outcome 3 Mass grip strength (\% of normal side).

Analysis 1.4. Comparison 1 Bone scaffolding (graft/substitute) versus plaster cast, Outcome 4 Pain at 6 months (VAS: 0 (none) to $100 \mathrm{~mm}$ (unbearable)).

Analysis 1.5. Comparison 1 Bone scaffolding (graft/substitute) versus plaster cast, Outcome 5 Long term pain. . . . 54

Analysis 1.6. Comparison 1 Bone scaffolding (graft/substitute) versus plaster cast, Outcome 6 Non-recovery of full range of movement. . . . . . . . . . . . . . . . . . . . . . . . . . . . . . . . . . . . 54

Analysis 1.7. Comparison 1 Bone scaffolding (graft/substitute) versus plaster cast, Outcome 7 Range of movement (\% of normal side). . . . . . . . . . . . . . . . . . . . . . . . . . . . . . . . . . . 55

Analysis 1.8. Comparison 1 Bone scaffolding (graft/substitute) versus plaster cast, Outcome 8 Complications. . . . 56

Analysis 1.9. Comparison 1 Bone scaffolding (graft/substitute) versus plaster cast, Outcome 9 Anatomical displacement. 58

Analysis 1.10. Comparison 1 Bone scaffolding (graft/substitute) versus plaster cast, Outcome 10 Anatomical measurements. . . . . . . . . . . . . . . . . . . . . . . . . . . . . . . . . .

Analysis 1.11. Comparison 1 Bone scaffolding (graft/substitute) versus plaster cast, Outcome 11 Deformity (cosmetic and structural). . . . . . . . . . . . . . . . . . . . . . . . . . . . . . . . . . . .

Analysis 2.1. Comparison 2 Bone substitute versus control (plaster or external fixation), Outcome 1 Unsuccessful functional outcome.

Analysis 2.2. Comparison 2 Bone substitute versus control (plaster or external fixation), Outcome 2 Grip strength (\% or normal side).

Analysis 2.3. Comparison 2 Bone substitute versus control (plaster or external fixation), Outcome 3 Pain.

Analysis 2.4. Comparison 2 Bone substitute versus control (plaster or external fixation), Outcome 4 Range of movement (\% of normal side).

Analysis 2.5. Comparison 2 Bone substitute versus control (plaster or external fixation), Outcome $510 \%$ or more deficit in range of motion compared with normal side.

Analysis 2.6. Comparison 2 Bone substitute versus control (plaster or external fixation), Outcome 6 Complications. .

Analysis 2.7. Comparison 2 Bone substitute versus control (plaster or external fixation), Outcome 7 Anatomical measurements.

Analysis 2.8. Comparison 2 Bone substitute versus control (plaster or external fixation), Outcome 8 Unsuccessful radiographic outcome measures. . . . . . . . . . . . . . . . . . . .

Analysis 3.1. Comparison 3 Bone graft, external fixation then plaster cast versus external fixation, Outcome 1 Poor function and grip strength (at 1 year).

Analysis 3.2. Comparison 3 Bone graft, external fixation then plaster cast versus external fixation, Outcome 2 Mass grip strength $(\%$ of normal side). . . . . . . . . . . . . . . . . . . . . . . . . . . . . . . . . . . . . . .

Analysis 3.3. Comparison 3 Bone graft, external fixation then plaster cast versus external fixation, Outcome 3 Range of movement (\% of normal side). 
Analysis 3.4. Comparison 3 Bone graft, external fixation then plaster cast versus external fixation, Outcome 4 Complications

Analysis 3.5. Comparison 3 Bone graft, external fixation then plaster cast versus external fixation, Outcome 5 Anatomical measurements.

Analysis 3.6. Comparison 3 Bone graft, external fixation then plaster cast versus external fixation, Outcome 6 Deformity (severe malunion).

Analysis 4.1. Comparison 4 Bone substitute versus percutaneous pinning, Outcome 1 Palmar flexion (degrees). . .

Analysis 4.2. Comparison 4 Bone substitute versus percutaneous pinning, Outcome 2 Complications. . . . . . . .

Analysis 5.1. Comparison 5 Bone scaffolding (graft/substitute) versus external fixation, Outcome 1 Functional gradings.

Analysis 5.2. Comparison 5 Bone scaffolding (graft/substitute) versus external fixation, Outcome 2 Non recovery of full grip strength.

Analysis 5.3. Comparison 5 Bone scaffolding (graft/substitute) versus external fixation, Outcome 3 Mass grip strength (\% of normal side).

Analysis 5.4. Comparison 5 Bone scaffolding (graft/substitute) versus external fixation, Outcome 4 Persistent pain (during carrying or lifting). . . . . . . . . . . . . . . . . . . . . . . . . . . . . . . . .

Analysis 5.5. Comparison 5 Bone scaffolding (graft/substitute) versus external fixation, Outcome 5 Non-recovery of full range of movement. . . . . . . . . . . . . . . . . . . . . . . . . . . . . . . . . . .

Analysis 5.6. Comparison 5 Bone scaffolding (graft/substitute) versus external fixation, Outcome 6 Range of movement (\%

Analysis 5.7. Comparison 5 Bone scaffolding (graft/substitute) versus external fixation, Outcome 7 Complications. .

Analysis 5.8. Comparison 5 Bone scaffolding (graft/substitute) versus external fixation, Outcome 8 Anatomical displacement.

Analysis 5.9. Comparison 5 Bone scaffolding (graft/substitute) versus external fixation, Outcome 9 Anatomical measurements.

Analysis 5.10. Comparison 5 Bone scaffolding (graft/substitute) versus external fixation, Outcome 10 Long term redisplacement.

Analysis 5.11. Comparison 5 Bone scaffolding (graft/substitute) versus external fixation, Outcome 11 Deformity (cosmetic and structural).

Analysis 6.1. Comparison 6 Bone allograft versus autograft, Outcome 1 Moderate or severe restrictions in everyday life.

Analysis 6.2. Comparison 6 Bone allograft versus autograft, Outcome 2 Functional gradings. . . . . . . . . . . .

Analysis 6.3. Comparison 6 Bone allograft versus autograft, Outcome 3 Grip strength (\% of normal hand). . . . .

Analysis 6.4. Comparison 6 Bone allograft versus autograft, Outcome 4 Discomforting or worse wrist pain. . . .

Analysis 6.5. Comparison 6 Bone allograft versus autograft, Outcome 5 Range of movement (degrees). . . . . . . .

Analysis 6.6. Comparison 6 Bone allograft versus autograft, Outcome 6 Complications. . . . . . . . . . . . . . .

Analysis 6.7. Comparison 6 Bone allograft versus autograft, Outcome 7 Dissatisfaction (only poor or fair rating of treatment outcome).

Analysis 6.8. Comparison 6 Bone allograft versus autograft, Outcome 8 Anatomical measurements (1 year). . . .

NOTES . . . . . . . . . . . . . . . . . . . . . . . . . . . . . . . . . . . . . . . . 86

INDEX TERMS . . . . . . . . . . . . . . . . . . . . . . . . . . . . . . . . . . . . 86 


\title{
Bone grafts and bone substitutes for treating distal radial fractures in adults
}

\author{
Helen HG Handoll ${ }^{1}$, Adam C Watts ${ }^{2}$ \\ ${ }^{1}$ Centre for Rehabilitation Sciences (CRS), Research Institute for Health Sciences and Social Care, University of Teesside, Middlesbor- \\ ough, UK. ${ }^{2}$ Department of Orthopaedic Surgery, Edinburgh Royal Infirmary, Edinburgh, UK \\ Contact address: Helen HG Handoll, Centre for Rehabilitation Sciences (CRS), Research Institute for Health Sciences and Social \\ Care, University of Teesside, School of Health and Social Care, Middlesborough, Tees Valley, TS1 3BA, UK. h.handoll@tees.ac.uk. \\ H.Handoll@ed.ac.uk.
}

Editorial group: Cochrane Bone, Joint and Muscle Trauma Group.

Publication status and date: Edited (no change to conclusions), published in Issue 3, 2009.

Review content assessed as up-to-date: 6 June 2007.

Citation: Handoll HHG, Watts AC. Bone grafts and bone substitutes for treating distal radial fractures in adults. Cochrane Database of Systematic Reviews 2008, Issue 2. Art. No.: CD006836. DOI: 10.1002/14651858.CD006836.pub2.

Copyright (C) 2009 The Cochrane Collaboration. Published by John Wiley \& Sons, Ltd.

\begin{abstract}
A B S T R A C T
Background

Surgical treatment of fractures of the distal radius can involve the implantation of bone scaffolding materials (bone grafts and substitutes) into bony defects that frequently arise after fracture reduction.
\end{abstract}

\section{Objectives}

To review the evidence from randomised controlled trials evaluating the implanting of bone scaffolding materials for treating distal radial fractures in adults.

\section{Search strategy}

We searched the Cochrane Bone, Joint and Muscle Trauma Group Specialised Register (June 2007), the Cochrane Central Register of Controlled Trials, MEDLINE, EMBASE and other databases, conference proceedings and reference lists. No language restrictions were applied.

\section{Selection criteria}

Randomised or quasi-randomised controlled clinical trials evaluating the use of bone scaffolding for treating distal radial fracture in adults.

\section{Data collection and analysis}

Two people independently selected studies and undertook assessment and data collection.

\section{Main results}

Ten heterogenous trials involving 874 adults with generally unstable fractures were grouped into six comparisons. No trial had proven allocation concealment.

Four trials (239 participants) found implantation of bone scaffolding (autogenous bone graft (one trial); Norian SRS - a bone substitute (two trials); methylmethacrylate cement (one trial)) improved anatomical outcomes compared with plaster cast alone; and two found 
it improved function. Reported complications of bone scaffolding were transient discomfort resulting from extraosseous deposits of Norian SRS; with surgical removal of one intra-articular deposit.

One trial (323 participants) comparing bone substitute (Norian SRS) versus plaster cast or external fixation found no difference in functional or anatomical outcomes at one year. Statistically significant complications in the respective groups were extraosseous Norian SRS deposits and pin track infection.

One trial (48 participants with external fixation) found that autogenous bone graft did not significantly change outcome. There was one serious donor-site complication.

One trial (21 participants) found some indication of worse outcomes for hydroxyapatite bone cement compared with Kapandjis intrafocal pinning.

Three trials (180 participants) found bone scaffolding (autogenous bone graft (one trial); Norian SRS (one trial); methylmethacrylate cement (one trial)) gave no significant difference in functional outcomes but some indication of better anatomical outcomes compared with external fixation. Most reported complications were associated with external fixation; extraosseous deposits of Norian SRS occurred in one trial.

One trial (93 participants with dorsal plate fixation) found autografts slightly improved wrist function compared with allogenic bone material but with an excess of donor site complications.

\section{Authors' conclusions}

Bone scaffolding may improve anatomical outcome compared with plaster cast alone but there is insufficient evidence to conclude on functional outcome and safety; or for other comparisons.

\section{PLAIN LANGUAGE SUMMARY}

\section{Bone grafts and bone substitutes for treating distal radial fractures in adults}

A 'broken wrist' (from a fracture at the lower end of the two forearm bones) often results from a fall onto an outstretched hand in older adults and from high-energy trauma, such as a road traffic accident, in young adults. Surgery may be considered for more seriously displaced fractures. Surgical treatment can involve the implantation of bone scaffolding materials (bone grafts and substitutes) into bony defects that may affect the stability of the fracture fragments after they have been put back into place.

This review looked at the evidence from randomised controlled trials evaluating the use of bone scaffolding.

Ten very different trials involving 874 adults with generally unstable fractures were grouped into six comparisons. No trial used a bestpractice method for preventing selection bias.

Four trials (239 participants) found implantation of bone scaffolding (autogenous - from the patient - bone graft (one trial); Norian SRS - a bone substitute (two trials); methylmethacrylate cement (one trial)) improved anatomical outcomes compared with plaster cast alone; and two found it improved function. Reported complications of bone scaffolding were transient discomfort resulting from deposits of Norian SRS outside the bone. One deposit required surgical removal.

One trial (323 participants) comparing Norian SRS versus plaster cast or external fixation found no difference in functional or anatomical outcomes at one year. External deposits of bone cement and pin track infection were the only significant differences between the two groups.

One trial (48 participants) found that autogenous (from the patient) bone graft in the context of external fixation did not significantly change outcome. There was one serious donor-site complication.

One trial (21 participants) found some indication of worse outcomes with bone cement compared with percutaneous (through the skin) pinning.

Three trials (180 participants) found bone scaffolding (autogenous bone graft (one trial); Norian SRS (one trial); methylmethacrylate cement (one trial)) gave no significant difference in functional outcomes but some indication of better anatomical outcomes compared 
with external fixation. Most reported complications were associated with external fixation; deposits of Norian SRS outside the bone occurred in one trial.

One trial (93 participants treated with plate fixation) comparing allogenic bone material (from other people) versus autogenic bonegraft found slightly improved wrist function for the autograft group but an excess of complications relating to graft harvesting.

The review concluded that while bone scaffolding may improve anatomical outcome compared with plaster cast immobilisation alone, there is insufficient evidence to conclude on function and safety; or on outcome for other comparisons.

\section{B A C K G RO U N D}

Note: This is one of five reviews that will cover all surgical interventions for treating distal radial fractures in adults. Each review will provide updated evidence for one of the several surgical categories that are presented together in the currently available review (Handoll 2003a). Following publication of the five reviews, Handoll 2003a will be converted to an 'umbrella' review summarising the evidence for surgical treatment for these fractures.

\section{Description of the condition: distal radial fracture in adults}

Fractures of the distal radius, often referred to as "wrist fractures", are common in both children and adults. They are usually defined as occurring in the distal radius within three centimetres of the radiocarpal joint, where the lower end of the radius interfaces with two (the lunate and the scaphoid) of the eight bones forming the carpus (the wrist). The majority are closed injuries, the overlying skin remaining intact.

Distal radial fractures are one of the most common fractures in adults, occurring predominantly in white and older populations in the developed world (Sahlin 1990; Singer 1998; Van Staa 2001). In women, the incidence increases with age from around 40 years. Before this age, the incidence is higher in men (Singer 1998). A multi-centre study in the United Kingdom of patients aged 35 years and above with distal radius fracture reported an annual incidence of 9/10,000 in men and 37/10,000 in women (O'Neill 2001).

Young adults usually sustain this injury as a result of high-energy trauma, such as a road traffic accident. In older adults, especially females, the fracture more often results from low-energy or moderate trauma, such as falling from standing height. This reflects the greater fragility of the bone, resulting from osteoporosis. It has been estimated that, at 50 years of age, a white woman in the USA or Northern Europe has a 15\% lifetime risk of a distal radius fracture whereas a man has a lifetime risk of just over two per cent (Cummings 1985). More recent estimates (Van Staa 2001) of lifetime risk of radius or ulna fracture at 50 years of age are similar: $16.6 \%$ for women versus $2.9 \%$ for men.

Distal radial fractures are usually treated on an outpatient basis. It is estimated that around $20 \%$ of patients (mainly older people) require hospital admission (Cummings 1985; O’Neill 2001). This figure includes all people receiving surgery.

\section{Classification}

Surgeons have classified fractures by anatomical configuration and fracture pattern to help in their management. Simple classifications were based on clinical appearance and often named after those who described them. In the distal radius, the term "Colles' fracture" is still used for a fracture in which there is an obvious and typical clinical deformity (commonly referred to as a 'dinner fork deformity') - dorsal displacement, dorsal angulation, dorsal comminution (fragmentation), and radial shortening. The introduction of X-rays and other imaging methods made it clear that the characteristic deformity may be associated with a range of different fracture patterns, which may be important determinants of outcome, and therefore the way in which treatment is conducted. For example, the fracture through the distal radius may be extraarticular (leaving the articular or joint surface of the radius intact) or intra-articular (the articular surface is disrupted, sometimes in a complex manner). Numerous classifications have been devised to define and group different fracture patterns (Chitnavis 1999). Brief descriptions of five commonly cited classification systems are presented in Table 1 (Cooney 1993; Frykman 1967; Melone 1993; Muller 1991; Older 1965). 
Table 1. Commonly used classification systems

\begin{tabular}{|c|c|c|}
\hline Name (reference ID) & Brief outline & Comment \\
\hline $\begin{array}{l}\text { AO (Arbeitsgemeinschaft fur Osteosynthe- } \\
\text { sefragen)(Muller 1991) }\end{array}$ & $\begin{array}{l}\text { This system is organised in order of increas- } \\
\text { ing fracture severity. It divides the fractures } \\
\text { into three major groups: group A (extra-ar- } \\
\text { ticular), group B (simple/partial intra-artic- } \\
\text { ular), and group C (complex/complete in- } \\
\text { tra-articular). These three groups are then } \\
\text { subdivided, yielding } 27 \text { different fracture } \\
\text { types. }\end{array}$ & $\begin{array}{l}\text { There is no assessment of the extent of frac- } \\
\text { ture displacement. }\end{array}$ \\
\hline $\begin{array}{l}\text { Frykman } \\
\text { (Frykman 1967) }\end{array}$ & $\begin{array}{l}\text { This system distinguishes between extra- } \\
\text { articular fractures and intra-articular frac- } \\
\text { tures of the radiocarpal and radio-ulnar } \\
\text { joints, and the presence or absence of an } \\
\text { associated distal ulnar (ulnar styloid) frac- } \\
\text { ture. There are } 8 \text { types labelled I to VIII (1 } \\
\text { to } 8 \text { ): the higher the number, the greater } \\
\text { complexity of the fracture. }\end{array}$ & $\begin{array}{l}\text { There is no assessment of the extent or di- } \\
\text { rection of fracture displacement, or of com- } \\
\text { minution. }\end{array}$ \\
\hline $\begin{array}{l}\text { Melone } \\
\text { (Melone 1993) }\end{array}$ & $\begin{array}{l}\text { This system identifies } 5 \text { fracture types, } \\
\text { based on } 4 \text { major fracture components: the } \\
\text { radial shaft, the radial styloid, and the dor- } \\
\text { sal-medial and volar-medial fragments. }\end{array}$ & This is for intra-articular fractures only. \\
\hline $\begin{array}{l}\text { Older } \\
\text { (Older 1965) }\end{array}$ & $\begin{array}{l}\text { This system divides fractures into } 4 \text { types, } \\
\text { labelled I to VI ( } 1 \text { to } 4 \text { ) of increasing sever- } \\
\text { ity. The types are defined according to ex- } \\
\text { tent of displacement (angulation and radial } \\
\text { shortening)and comminution. }\end{array}$ & $\begin{array}{l}\text { There is no consideration of radio-ulnar } \\
\text { joint involvement. }\end{array}$ \\
\hline 'Universal Classification' (Cooney 1993) & $\begin{array}{l}\text { This system divides fractures into } 4 \text { main } \\
\text { types, labelled I to VI ( } 1 \text { to } 4 \text { ), distinguish- } \\
\text { ing between extra-articular and intra-artic- } \\
\text { ular fractures and displaced and non-dis- } \\
\text { placed fractures. Displaced fracture types } \\
\text { II and IV are further subdivided based on } \\
\text { reducibility (whether the fracture can be } \\
\text { reduced; that is whether the bone frag- } \\
\text { ments can be put back in place) and stabil- } \\
\text { ity (whether, once reduced, the fragments } \\
\text { will remain so). }\end{array}$ & $\begin{array}{l}\text { This does not distinguish between the ra- } \\
\text { diocarpal and radio-ulnar joints. Addition- } \\
\text { ally, there is a 'trial by treatment'. }\end{array}$ \\
\hline
\end{tabular}




\section{Description of the intervention: bone grafts and bone graft substitutes}

In the last century, most distal radius fractures in adults were treated conservatively, by reduction (the alignment of the bony fragments) of the fracture when displaced, and stabilisation in a plaster cast or other external brace. The results of such treatment, particularly in older people with bones weakened by osteoporosis, are not consistently satisfactory (Handoll 2003b), and surgical interventions have been developed aimed at more accurate reduction and more reliable stabilisation. However, particularly in people with osteoporotic bone, metaphyseal comminution and impaction may result in a bony void in the distal radius that may be associated with loss of reduction and malunion. This defect can be filled with some biocompatible material; for example, an autograft (autogenous bone graft) that is obtained from the patients themselves. Such bone is 'harvested' or extracted from a donor site; usually the iliac crest (a part of the pelvic girdle). However, autograft harvesting carries a significant risk of complication, including donor site pain, haematoma, infection and nerve injury ( Arrington 1996). A common alternative is an allograft (allogenic bone graft), obtained from cadaveric donors or live donors undergoing procedures such as total hip replacement. This avoids the morbidity associated with autografts but adds the risks of disease transmission and of engendering an immune response. However, the preparation of allografts (sterilisation and freeze drying for safe storage) reduces the antigenicity (induced immune response) but also eliminates bone-forming cellular elements and reduces structural performance. Synthetic alternatives eliminate the risk of disease transmission but their properties vary considerably. Some, such as bone cement, are essentially space fillers and do not bond to the bone; others such as bioresorbable ceramics act as temporary scaffolds for new bone (osteoconduction) and are then absorbed during the healing process (Carson 2007). Bone grafts or substitutes are generally insufficient to maintain fracture reduction on their own and are often combined with fracture fixation such as Kirschner wires, plates and screws, or external fixators (typically metal pins or screws driven into the bone on either side of the fracture via small skin incisions and fixed externally with a plaster cast or an external fixator frame).

\section{Complications}

Complications from this injury are frequent (McKay 2001). Some are associated with the injury itself: as well as concomitant injuries to soft tissues, fracture displacement can further compromise blood vessels, tendons and nerves, with median nerve dysfunction being the most common complication (Belsole 1993). The etiology of complex regional pain syndrome type 1, also termed reflex sympathetic dystrophy (RSD), algodystrophy, Sudeck's atrophy and shoulder-hand syndrome (Fernandez 1996), is often unclear. RSD is a major complication (Atkins 2003) requiring many months of physiotherapy to alleviate symptoms (pain and tenderness, impairment of joint mobility, swelling, dystrophy (muscle wasting), vasomotor instability (poor control of blood vessel dilation)) in serious cases. Late complications include adaptive carpal instability (dynamic instability resulting from malalignment of distal radius and carpal bones within the wrist that is associated with pain, decreased grip strength and clicking) and post-traumatic arthritis which can occur several months or years after injury (Knirk 1986; Taleisnik 1984).

Complications can also result from treatment and include residual finger stiffness resulting from faulty application of plaster casts ( Gartland 1951), and infection and tissue-damage from surgery. Specific complications for bone grafts and substitutes include donor site morbidity for autografts, disease transmission from allografts, and problems resulting from soft-tissue and intra-articular deposits of bone substitute materials.

\section{Why it is important to do this review?}

A bony void is common after the reduction of many distal radial fractures. It is important to determine if inserting bone grafts and bone substitutes into this bony defect affects outcome, particularly in terms of function and adverse effects, either versus conservative treatment or surgical fixation or as an adjunct to methods of surgical fixation. The answer to this question is likely to depend on fracture configuration, bone quality and other patient factors.

\section{O B J E C T I VES}

To evaluate the effectiveness of implanting bone scaffolding materials (bone grafts or bone substitutes) into bony defects resulting from fracture of the distal radius in skeletally mature people.

More specifically, we aimed to compare the effectiveness of:

- implanting bone scaffolding versus conservative treatment or surgical fixation (percutaneous pinning or external fixation or combinations of these);

- implanting bone scaffolding used in conjunction with any method of surgical fixation versus the same method of surgical fixation alone;

- different methods of bone scaffolding;

- different types and durations of immobilisation after bone scaffolding.

We consider outcome primarily in terms of patient-assessed functional outcome and satisfaction, and other measures of function and impairment, pain and discomfort, the incidence of complications, anatomical deformity and use of resources. 
Our intention to study the outcomes in different age groups and for different fracture types, especially whether they are extra-articular or intra-articular, was prevented by the lack of data and variation in the trial characteristics.

\section{METHODS}

\section{Criteria for considering studies for this review}

\section{Types of studies}

We considered all randomised or quasi-randomised (method of allocating participants to a treatment which is not strictly random e.g. by date of birth, hospital record number, alternation) controlled clinical trials evaluating the use of bone grafts or substitutes for treating distal radial fractures in adults.

\section{Types of participants}

Skeletally mature patients of either sex with a fracture of the distal radius were included. Trials containing adults and children would have been included provided the proportion of children was clearly small $(<5 \%)$, or separate data for adults could be obtained. Trials containing different fracture types would have been included only if separate data were available for participants with distal radial fractures. Also included were trials recruiting people whose fractures had redisplaced within two weeks of conservative management. An exception was made regarding this last criterion in the inclusion of a trial of that recruited patients whose fractures had redisplaced after a second reduction between 14 and 18 days after injury.

\section{Types of interventions}

Randomised trials evaluating the effectiveness of implanting bone scaffolding materials into bony defects resulting from fracture of the distal radius in adults. This included the following comparisons.

(1) Implantation of bone grafts or substitutes alone versus conservative interventions such as plaster cast immobilisation.

(2) Implantation of bone grafts or substitutes along with surgical fixation (percutaneous pinning, external fixation, internal fixation or combinations of these) versus the same method of surgical fixation alone.

(3) Implantation of bone grafts or substitutes alone versus surgical fixation (percutaneous pinning, external fixation, or combinations of these).

(4) Comparisons evaluating different types of bone scaffolding (e.g. autografts versus allografts; grafts versus bone substitutes; bioabsorbable versus bio-inert substitute materials). This does not include comparisons of different preparations or compositions of the same broad category of bone substitutes.

(5) Comparisons evaluating different types and durations of immobilisation after bone scaffolding.

For the first three comparisons, the use of supplementary pinning solely to secure the placement of grafts/scaffolding was considered on a case by case basis.

We included trials in which surgery involving the insertion of bone grafts or substitutes took place up to 18 days after initial conservative management.

This review does not cover bone tissue engineering and thus we have not included trials testing bone scaffolding materials that are being used as delivery systems for biological agents, such as bone morphogenic proteins, involved in the bone remodelling process (Carson 2007). Although no trials were found, we also would have excluded trials evaluating different surgical techniques associated with implantation of bone scaffolding; this decision may be revisited in the future.

\section{Types of outcome measures}

Our primary outcome of choice was the number of people with an uncomplicated and swift restoration of a pain-free fully-functioning wrist and arm with acceptable anatomic restoration and appearance. However, compatible with the general assessment and presentation of outcome within the orthopaedic literature, we report outcome in the following four categories.

\section{Primary outcomes}

\section{(1) Functional outcome and impairment}

- Patient functional assessment instruments such as Short Form-36 (SF-36), the Disability of the Arm, Shoulder, and Hand questionnaire (DASH) and the Patient-Rated Wrist Evaluation (PRWE) (MacDermid 2000)

- Return to previous occupation, including work, and activities of daily living

- Grip strength

- Pain

- Range of movement (wrist and forearm mobility): range of movement for the wrist is described in terms of six parameters: flexion (ability to bend the wrist downwards) and extension (or upwards); radial deviation (ability to bend the wrist sideways on the thumb side) and ulnar deviation (on the little finger side); and pronation (ability to turn the forearm so that the palm faces downwards) and supination (palm faces upwards)

\section{(2) Clinical outcome}

- Residual soft tissue swelling 
- Early and late complications associated with distal radial fractures or their treatment, including reflex sympathetic dystrophy (RSD), late tendon rupture and post traumatic osteoarthritis

- Cosmetic appearance

- Patient satisfaction with treatment

\section{Secondary outcomes}

\section{(3) Anatomical outcome (anatomical restoration and residual} deformity)

- Radiological parameters include radial length or shortening and shift, dorsal angulation, radial inclination or angle, ulnar variance, and for intra-articular fractures: step off and gap deformity of the articular surface (Fernandez 1996; Kreder 1996). Composite measures include malunion and total radiological deformity. Definitions of four of the most commonly reported radiological parameters are presented in Table 2 .

Table 2. Definitions of key radiological parameters

\begin{tabular}{|c|c|c|}
\hline Parameter & Definition & Normal value \\
\hline $\begin{array}{l}\text { Dorsal angulation (dorsal or volar or pal- } \\
\text { mar tilt) }\end{array}$ & $\begin{array}{l}\text { Angle between a) the line which connects } \\
\text { the most distal points of the dorsal and } \\
\text { volar cortical rims of the radius and b) the } \\
\text { line drawn perpendicular to the longitudi- } \\
\text { nal axis of the radius. Side view of wrist } \\
\text { with the forearm in neutral rotation. }\end{array}$ & $\begin{array}{l}\text { Palmar or volar tilt: approximately 11-12 } \\
\text { degrees. }\end{array}$ \\
\hline Radial length & $\begin{array}{l}\text { Distance between a) a line drawn at the tip } \\
\text { of the radial styloid process, perpendicular } \\
\text { to the longitudinal axis of the radius and b) } \\
\text { a second perpendicular line at the level of } \\
\text { the distal articular surface of the ulnar head. } \\
\text { Frontal view with the forearm in neutral } \\
\text { rotation. }\end{array}$ & Approximately 11-12 mm. \\
\hline Radial angle or radial inclination & $\begin{array}{l}\text { Angle between a) the line drawn from the } \\
\text { tip of the radial styloid process to the ulnar } \\
\text { corner of the articular surface of the distal } \\
\text { end of the radius and b) the line drawn } \\
\text { perpendicular to the longitudinal axis of } \\
\text { the radius. Frontal view with the forearm } \\
\text { in neutral rotation. }\end{array}$ & Approximately 22-23 degrees. \\
\hline Ulnar variance & $\begin{array}{l}\text { Vertical distance between a) a line drawn } \\
\text { parallel to the proximal surface of the lu- } \\
\text { nate facet of the distal radius and b) a line } \\
\text { parallel to the articular surface of the ul- }\end{array}$ & $\begin{array}{l}\text { Usually negative variance (e.g. }-1 \mathrm{~mm} \text { ) or } \\
\text { neutral variance. }\end{array}$ \\
\hline
\end{tabular}


Table 2. Definitions of key radiological parameters (Continued)

nar head. Frontal view with the forearm in

neutral rotation

\section{(4) Resource use}

- Hospital stay, number of outpatient attendances, physiotherapy and other costs.

\section{Intervention-specific outcomes}

For autografts, outcomes including pain and complications associated with the surgical removal of bone from the donor site were collected, where reported, and presented in the analyses. Other adverse outcomes of bone scaffolding are already covered under 'Clinical outcome' (see above).

\section{Search methods for identification of studies}

\section{Electronic searches}

We searched the Cochrane Bone, Joint and Muscle Trauma Group Specialised Register (June 2007), the Cochrane Central Register of Controlled Trials (in The Cochrane Library 2007, Issue 2), MEDLINE (1996 to June week 1 2007), EMBASE (1988 to 2007 week 22), CINAHL (1982 to June week 1 2007). No language restrictions were applied.

The Cochrane Library (Wiley InterScience) search strategy is shown in Appendix 1.

In MEDLINE (OVID-WEB) the following search strategy was combined with all three sections of the optimal MEDLINE search strategy for randomised trials (Higgins 2005).

1. exp Radius Fractures/

2. Wrist Injuries/

3. (((distal adj3 (radius or radial)) or wrist or colles or smith\$2) adj3 fracture\$).ti,ab.

4. or/1-3

Similar search strategies were used for EMBASE (OVID-WEB) and CINAHL (OVID-WEB): see Appendix 2.

We also searched Current Controlled Trials at www.controlledtrials.com (accessed June 2007) and the UK National Research Register at www.update-software.com/national/ (up to Issue 2, 2007) for ongoing and recently completed trials.

\section{Searching other resources}

We searched reference lists of articles. We also included the findings from handsearches of the British Volume of the Journal of Bone and Joint Surgery supplements (1996 onwards) and abstracts of the American Society for Surgery of the Hand annual meetings (2000 to 2006: www.assh.org/), the American Orthopaedic Trauma Association annual meetings (1996 to 2006: http://www.hwbf.org/ ota/am/) and American Academy of Orthopaedic Surgeons annual meeting (2004 to 2007: www.aaos.org/wordhtml/libscip.htm). We also included handsearch results from the final programmes of SICOT (1996 \& 1999) and SICOT/SIROT (2003), EFFORT (2007) and the British Orthopaedic Association Congress (2000, 2001, 2002, 2003, 2005 and 2006), and various issues of Orthopaedic Transactions and Acta Orthopaedica Scandinavica Supplementum.

We also scrutinised weekly downloads of "Fracture" articles in new issues of 15 journals (Acta Orthop Scand; Am J Orthop; Arch Orthop Trauma Surg; Clin J Sport Med; Clin Orthop; Foot Ankle Int; Injury; J Am Acad Orthop Surg; J Arthroplasty; J Bone Joint Surg Am; J Bone Joint Surg Br; J Foot Ankle Surg; J Orthop Trauma; J Trauma; Orthopedics) from AMEDEO (www.amedeo.com).

\section{Data collection and analysis}

\section{Selection of studies}

Both review authors independently assessed potentially eligible trials identified via the search for inclusion using a pre-piloted form. This was supplemented by trials already independently selected by two people from a previous review (Handoll 2003a). Any disagreement was resolved by discussion.

\section{Data extraction and management}

Using a data extraction form, both review authors independently extracted trial details and data for new trials, and one author $(\mathrm{HH})$ repeated data extraction of trials already included in Handoll 2003a and checked for consistency with her previous data extraction. HH entered the data into RevMan. Any disagreements for the new trial were resolved by discussion. We contacted, with mixed success, several trialists for additional information and data. 
Results were collected for the final follow-up time for which these were available. We also noted instances where clinically important differences had been reported at intermediate follow-up assessments.

\section{Assessment of risk of bias in included studies}

Both review authors independently assessed the methodological quality of the newly included trial using a pre-piloted form. One author $(\mathrm{HH})$ repeated her assessment of the trials already included in Handoll 2003a. All disagreements were resolved by discussion. Titles of journals, names of authors or supporting institutions were not masked at any stage. A modification of the quality assessment tool used in the current 'umbrella' review was used. Instead of scores, each item was graded either ' $\mathrm{Y}$ ', '?' or ' $\mathrm{N}$ ', respectively indicating that the quality criteria were met for the item ("Yes"), or possibly or only partially met for the item ("Possible, partial"), or not met ("No"). The rating scheme covering 11 aspects of trial validity plus brief notes of coding guidelines for selected items are given in Table 3.

Table 3. Methodological quality assessment scheme

\begin{tabular}{lll}
\hline Items & Scores & Notes \\
\hline $\begin{array}{l}\text { (1) Was the assigned treatment adequately } \\
\text { concealed prior to allocation? }\end{array}$ & $\begin{array}{l}\text { Y = method did not allow disclosure of as- } \\
\text { signment. } \\
\text { ?= small but possible chance of disclosure } \\
\text { of assignment or unclear. } \\
\text { N = quasi-randomised, or open list or ta- } \\
\text { bles. }\end{array}$ \\
\hline
\end{tabular}

(2) Were the outcomes of participants who withdrew described and included in the analysis (intention-to-treat)?

$\mathrm{Y}=$ withdrawals well described and accounted for in analysis.

? = withdrawals described and analysis not possible, or probably no withdrawals.

$\mathrm{N}=$ no mention, inadequate mention, or obvious differences and no adjustment.

(3) Were the outcome assessors blinded to $Y=$ effective action taken to blind assessors. treatment status?

? = small or moderate chance of unblinding of assessors, or some blinding of outcomes attempted.

$\mathrm{N}=$ not mentioned or not possible.

(4) Were important baseline characteristics reported and comparable?
$\mathrm{Y}=$ good comparability of groups, or confounding adjusted for in analysis.

? = confounding small, mentioned but not adjusted for, or comparability reported in text without confirmatory data.

$\mathrm{N}$ = large potential for confounding, or not
Although many characteristics including hand dominance are important, the principal confounders are considered to be age, gender, type of fracture. 
discussed.

(5) Were the trial participants blind to assignment status after allocation?
$\mathrm{Y}=$ effective action taken to blind participants.

$?=$ small or moderate chance of unblinding of participants.

$\mathrm{N}=$ not possible, or not mentioned (unless double-blind), or possible but not done.

(6) Were the treatment providers blind to $Y=$ effective action taken to blind treatment assignment status? providers.

? = small or moderate chance of unblinding of treatment providers.

$\mathrm{N}=$ not possible, or not mentioned (unless double-blind), or possible but not done.

(7) Were care programmes, other than the $Y=$ care programmes clearly identical. trial options, identical?
? = clear but trivial differences, or some evidence of comparability.

$\mathrm{N}=$ not mentioned or clear and important differences in care programmes.
Examples of clinically important differences in other interventions are: time of intervention, duration of intervention, anaesthetic used within broad categories, operator experience, difference in rehabilitation.

(8) Were the inclusion and exclusion criteria for entry clearly defined?

$\mathrm{Y}=$ clearly defined (including type of fracture).

? = inadequately defined.

$\mathrm{N}=$ not defined.

(9) Were the outcome measures used clearly $\mathrm{Y}=$ clearly defined. defined? $?=$ inadequately defined.

$\mathrm{N}=$ not defined.

(10) Were the accuracy and precision, $\mathrm{Y}=$ optimal. with consideration of observer variation, of $\quad ?=$ adequate. the outcome measures adequate; and were $\mathrm{N}=$ not defined, not adequate. these clinically useful and did they include active follow up?

(11) Was the timing (e.g. duration of $\mathrm{Y}=$ optimal. ( $>1$ year) surveillance)clinically appropriate? 


\section{Measures of treatment effect}

Where available, quantitative data reported in individual trial reports for outcomes listed in the inclusion criteria are presented in the text and in the analyses. Relative risks with $95 \%$ confidence intervals were calculated for dichotomous outcomes, and mean differences with $95 \%$ confidence intervals were calculated for continuous outcomes.

\section{Unit of analysis issues}

The unit of randomisation in these trials is usually the individual patient. Exceptionally, as in the case of trials including people with bilateral fractures, data for trials may be presented for fractures or limbs rather than individual patients. This did not occur in the trials included so far in this review.

\section{Dealing with missing data}

Where possible, we performed intention-to-treat analyses to include all people randomised to the intervention groups. The investigation of the effect of drop outs and exclusions by conducting best and worst scenario analyses was either not possible or not warranted. We were alert to the potential mislabelling or nonidentification of standard errors for standard deviations. Unless missing standard deviations could be derived from confidence interval data, we did not assume values in order to present these in the analyses.

\section{Assessment of heterogeneity}

Heterogeneity was assessed by visual inspection of the forest plot (analysis) along with consideration of the test for heterogeneity and the $\mathrm{I}^{2}$ statistic (Higgins 2003).

\section{Assessment of reporting biases}

There were insufficient data to assess publication bias; for example, by preparing a funnel plot.

\section{Data synthesis}

In the light of the few common outcomes and the clinical heterogeneity in the trials grouped in the same comparisons, very limited pooling was done. Initially, we used the fixed-effect model and $95 \%$ confidence intervals. Where there was clear heterogeneity, we looked at the results of using the random-effects model but then decided against pooling in each case.

\section{Subgroup analysis and investigation of heterogeneity}

There were no data available to carry out our pre-specified subgroup analyses by age, gender and type of fracture (primarily, extra-articular versus intra-articular fractures). Presentation in separate subgroups was also considered where there was a fundamental difference in bone scaffolding (such as bone graft versus bone substitute). Again there were no data available. To test whether subgroups were statistically significantly different from one another, we proposed to test the interaction using the technique outlined by Altman and Bland (Altman 2003).

\section{Sensitivity analysis}

There were no data available to carry out our pre-specified sensitivity analyses examining various aspects of trial and review methodology, including the study quality (specifically allocation concealment, outcome assessor blinding and reportage of surgical/clinical experience), and inclusion of trials only reported in abstracts (all were full reports).

\section{Interpretation of the evidence}

We graded the findings of the treatment comparisons according to the six categories of effectiveness used by contributors to Clinical Evidence (BMJ 2006) (see Table 4) to assist our interpretation.

Table 4. Categories of effectiveness (definitions)

\begin{tabular}{l|l|l}
\hline Rank & Category & Definition \\
\hline 1 & Beneficial & $\begin{array}{l}\text { Interventions for which effectiveness has been demonstrated by clear evidence from } \\
\text { randomised controlled trials, and for which expectation of harms is small compared } \\
\text { with the benefits. }\end{array}$ \\
\hline 2 & Likely to be beneficial & $\begin{array}{l}\text { Interventions for which effectiveness is less well established than for those listed } \\
\text { under "beneficial". }\end{array}$ \\
\hline 3 & Trade off between benefits and harms & $\begin{array}{l}\text { Interventions for which clinicians and patients should weigh up the beneficial and } \\
\text { harmful effects according to individual circumstances and priorities. }\end{array}$ \\
\hline 4 & Unknown effectiveness & $\begin{array}{l}\text { Interventions for which there is currently insufficient data or data of inadequate } \\
\text { quality. }\end{array}$
\end{tabular}


Table 4. Categories of effectiveness (definitions) (Continued)

\begin{tabular}{lll}
\hline 5 & Unlikely to be beneficial & $\begin{array}{l}\text { Interventions for which lack of effectiveness is less well established than for those } \\
\text { listed under "likely to be ineffective or harmful" }\end{array}$ \\
\hline 6 & Likely to be ineffective or harmful & $\begin{array}{l}\text { Interventions for which ineffectiveness or harmfulness has been demonstrated by } \\
\text { clear evidence. }\end{array}$ \\
\hline
\end{tabular}

The publication dates of the main reports of these trials span 17 years; Schmalholz 1989 being the earliest. Cassidy 2003 was a multi-centre trial with 20 centres in the USA, one in Canada,

\section{R E S U L T S}

\section{Description of studies}

See: Characteristics of included studies; Characteristics of excluded studies; Characteristics of ongoing studies.

\section{Results of the search}

The search for trials predated the development of this review, which is essentially an update of part of a previously published review (Handoll 2003a) covering all surgical intervention for these fractures. We have not documented the numbers of references retrieved by electronic searches. Updates of MEDLINE, EMBASE and CINAHL are now generated on a weekly basis. Of 17 potentially eligible studies put forward for study selection, 10 were included, six were excluded and one is ongoing.

Nine of the included trials were previously included in Handoll 2003a; this includes Cassidy 2003 (formerly FDA 1998), whose study ID has been changed to reflect the identification of a final report. An abstract report of Rajan 2006, the newly included trial, appeared (as Fornaro 2000) in 'Studies awaiting assessment' in Handoll 2003a.

\section{Included studies}

All of the included studies were fully reported in English language medical journals. Five included trials were initially located by handsearching. The rest were located in the following ways: The Cochrane Bone, Joint and Muscle Trauma Group Specialised Register (1); MEDLINE (3), National Research Register (1).

Details of the methods, participants, interventions and outcome measures of individual trials are provided in the 'Characteristics of included studies'.

\section{Setting} one in the UK and one in another European country. The other nine studies were single centre trials, mainly conducted in teaching hospitals. They each took place in one of four countries (Spain (1), Sweden (5), Switzerland (1),UK (2)).

\section{Participants}

The 10 included trials involved a total of 874 participants.

\section{Age and gender}

The percentage of females ranged from $69 \%$ (Widman 2002) to 100\% (Jeyam 2002; Kopylov 2002; Schmalholz 1989). The mean ages of the trial populations ranged from 51.5 years (Widman 2002) to 73 years (Jeyam 2002). All trial participants were skeletally mature. Six trials reported age restrictions: Cassidy 2003: 45 years or over; Jeyam 2002: 70 years or over; Kopylov 1999 and Kopylov 2002: women 50 to 80 years; men 60 to 80 years; Sanchez-Sotelo 2000: 50 to 85 years; Widman 2002: 20 to 70 years.

\section{Types of fractures}

All participants of five trials (Kopylov 1999; Kopylov 2002; McQueen 1996, Schmalholz 1989; Schmalholz 1990) and some of Rajan 2006 included fractures that had redisplaced, usually within two weeks. Entry into Schmalholz 1989 and Schmalholz 1990 was timed after the second reduction, which took place between 8 and 14 days after the first closed reduction in the first trial and between 14 and 18 days after injury in the second trial. The remaining trials involved primary treatment of people with acute fractures. It is likely that all fractures in these trials were closed; this was explicitly stated in Schmalholz 1989 and Schmalholz 1990. The majority of fractures were dorsally displaced. Seven trials included both extra-articular and intra-articular fractures, the exceptions 
being Schmalholz 1989 and Schmalholz 1990 (extra-articular fractures only) and Jeyam 2002 (intra-articular fractures only). Smith and Barton fractures were explicitly excluded in Cassidy 2003; and implicitly excluded in several other trials. Four trials (Cassidy 2003; McQueen 1996; Rajan 2006; Sanchez-Sotelo 2000) classified their fractures according to the AO system (Muller 1991), one (Schmalholz 1990) used the Frykman system (Frykman 1967), one (Jeyam 2002) used the Melone system (Melone 1993) and another (Widman 2002) used the Older system (Older 1965). Three trials (Kopylov 1999; Kopylov 2002; Schmalholz 1990) only described whether fractures were extra- or intra-articular. Two trials (Jeyam 2002; Sanchez-Sotelo 2000) provided no criteria of the extent of the displacement required for trial entry.

\section{Interventions}

The 10 included trials have been grouped according to the main comparison addressed by each trial. Nine trials belonged to the first four comparisons listed under 'Types of interventions'. The tenth trial tested a new comparison, whereby the control group was either conservative treatment or external fixation. There were no trials evaluating immobilisation after bone scaffolding (comparison 5 in 'Types of interventions'). A concise summary of the trial participants, fracture types, timing and details of the interventions is given in Table 5. Some indications of major differences in the trials grouped under the same comparison are highlighted below.

Table 5. Key characteristics of participants, fractures and interventions

\begin{tabular}{|c|c|c|c|c|c|}
\hline Study ID & Participants & $\begin{array}{l}\text { Fracture type and } \\
\text { classification }\end{array}$ & $\begin{array}{l}\text { Tim- } \\
\text { ing/ common inter- } \\
\text { ventions/duration }\end{array}$ & Intervention & Control \\
\hline Cassidy 2003 & $\begin{array}{l}323 ; 84 \% \text { female; } \\
\text { mean age } 64 \text { years. }\end{array}$ & $\begin{array}{l}\text { Unstable and / or } \\
\text { displaced unilateral } \\
\text { distal radius frac- } \\
\text { ture resulting from } \\
\text { a low energy im- } \\
\text { pact. Extra-articu- } \\
\text { lar (AO type: A2.1, } \\
\text { A2.2, A3.1, A3.2, } \\
\text { A3.3) or intra-ar- } \\
\text { ticular (C1.1, C1.2, } \\
\text { C1.3, C2.1, C2.2). }\end{array}$ & $\begin{array}{l}\text { Before } 5 \text { days from } \\
\text { injury. Closed re- } \\
\text { duction. } \\
\text { tional use of K-wires } \\
\text { for fracture stabili- } \\
\text { sation. Duration of } \\
\text { immobilisation dif- } \\
\text { fered in the two } \\
\text { groups. }\end{array}$ & $\begin{array}{l}\text { Bone substitute. } \\
\text { No- } \\
\text { rian SRS (calcium- } \\
\text { phosphate bone ce- } \\
\text { ment) injected per- } \\
\text { cutaneously } \\
\text { or through small } \\
\text { incision into cav- } \\
\text { ity (after clean-up) } \\
\text {. Below-elbow plas- } \\
\text { ter cast for } 2 \text { weeks. } \\
\text { Wrist and forearm } \\
\text { exercises started at } \\
2 \text { weeks. Removable } \\
\text { splint for } 4 \text { weeks. }\end{array}$ & $\begin{array}{l}\text { Closed reduc- } \\
\text { tion and cast ( } 108 \\
\text { people) or external } \\
\text { fixator ( } 54 \text { people) } \\
\text { for } 6 \text { to } 8 \text { weeks. } \\
\text { Wrist and forearm } \\
\text { exercises started af- } \\
\text { ter this. }\end{array}$ \\
\hline
\end{tabular}


Table 5. Key characteristics of participants, fractures and interventions (Continued)

\begin{tabular}{|c|c|c|c|c|c|}
\hline Jeyam 2002 & $\begin{array}{l}21 \text {; all female; mean } \\
\text { age } 73 \text { years. }\end{array}$ & $\begin{array}{l}\text { Displaced distal ra- } \\
\text { dius frac- } \\
\text { ture. Melone type } 1 \\
\text { or 2a fractures: in- } \\
\text { tra-articular. }\end{array}$ & $\begin{array}{l}\text { Recruitment criteria } \\
\text { within } 7 \text { days of in- } \\
\text { jury. Closed reduc- } \\
\text { tion. Short-arm cast } \\
\text { for } 4 \text { weeks. }\end{array}$ & $\begin{array}{l}\text { Bone substitute. } \\
\text { Hydroxyapatite } \\
\text { bone cement in- } \\
\text { serted through small } \\
\text { dorsal incision after } \\
\text { clean-up. Short-arm } \\
\text { cast for } 4 \text { weeks. }\end{array}$ & $\begin{array}{l}\text { Kapandji's intrafo- } \\
\text { cal pinning ( } 2 \text { or } 3 \\
\text { K-wires inserted at } \\
\text { fracture site). Short- } \\
\text { arm cast for } 4 \text { weeks. } \\
\text { K-wires removed at } \\
6 \text { weeks. }\end{array}$ \\
\hline Kopylov 1999 & $\begin{array}{l}40 ; \quad 90 \% \text { female; } \\
\text { mean age } 67 \text { years. }\end{array}$ & $\begin{array}{l}\text { Redisplaced } \\
\text { unstable distal ra- } \\
\text { dial fracture ( } 20 \text { de- } \\
\text { grees dorsal angula- } \\
\text { tion or } 2+\text { mm axial } \\
\text { compression or } 2+ \\
\text { mm incongruity in } \\
\text { radiocarpal or distal } \\
\text { radio-ulnar joints). } \\
\text { Extra-articular and } \\
\text { intra-articular. }\end{array}$ & $\begin{array}{l}\text { After } 7-10 \text { days } \\
\text { from initial reduc- } \\
\text { tion. Closed reduc- } \\
\text { tion in both groups. } \\
\text { Duration of immo- } \\
\text { bilisation differed in } \\
\text { the two groups. }\end{array}$ & $\begin{array}{l}\text { Bone substitute. } \\
\text { Fracture } \\
\text { exposed through }<5 \\
\mathrm{~cm} \text { dorsal incision. } \\
\text { After clean-up, No- } \\
\text { rian skeletal repair } \\
\text { system (SRS) - bone } \\
\text { cement - injected } \\
\text { to fill defect. Short } \\
\text { arm dorsal splint for } \\
2 \text { weeks, then wrist } \\
\text { mobilisation. }\end{array}$ & $\begin{array}{l}\text { Hoffman external } \\
\text { fixator } 5 \text { weeks. Two } \\
\text { pins inserted into } \\
\text { 2nd metacarpal and } \\
2 \text { into radial shaft. } \\
\text { Wrist mobilised af- } \\
\text { ter } 5 \text { weeks. }\end{array}$ \\
\hline Kopylov 2002 & $\begin{array}{l}20 \text {; all female; mean } \\
\text { age } 66 \text { years. }\end{array}$ & $\begin{array}{l}\text { Redis- } \\
\text { placed distal radial } \\
\text { fracture ( } 20 \text { degrees } \\
\text { dorsal angulation or } \\
2+\mathrm{mm} \text { axial short- } \\
\text { ening or } 2+\mathrm{mm} \\
\text { incongruity in ra- } \\
\text { dio-carpal or distal } \\
\text { radio-ulnar joints). } \\
\text { Extra-articular and } \\
\text { intra-articular. }\end{array}$ & $\begin{array}{l}\text { After } \\
7-10 \text { days from ini- } \\
\text { tial reduction. Plas- } \\
\text { ter cast immobilisa- } \\
\text { tion for } 1 \text { week, then } \\
\text { removable splint up } \\
\text { to } 3 \text { weeks. }\end{array}$ & $\begin{array}{l}\text { Bone substitute. } \\
\text { Closed re- } \\
\text { duction and fracture } \\
\text { exposed through }<5 \\
\mathrm{~cm} \\
\text { dorsal incision. Af- } \\
\text { ter open reduction, } \\
\text { as required, clean- } \\
\text { up, Norian skeletal } \\
\text { repair system (SRS) } \\
\text { - bone cement - } \\
\text { injected to fill de- } \\
\text { fect. Short arm dor- } \\
\text { sal splint for } 1 \text { week, } \\
\text { then wrist mobili- } \\
\text { sation and instruc- } \\
\text { tion. }\end{array}$ & $\begin{array}{l}\text { No change of cast or } \\
\text { re-reduction. Short } \\
\text { arm dorsal splint for } \\
1 \text { week, then wrist } \\
\text { mobilisation and in- } \\
\text { struction. }\end{array}$ \\
\hline McQueen 1996 & $\begin{array}{l}120 ; 89 \% \text { female; } \\
\text { mean age } 63 \text { years. }\end{array}$ & $\begin{array}{l}\text { Redis- } \\
\text { placed ( }>10 \text { degrees } \\
\text { dorsal angulation or } \\
>3 \mathrm{~mm} \text { radial short- } \\
\text { ening). AO types A } \\
\text { and C (extra-articu- } \\
\text { lar and intra-articu- } \\
\text { lar). }\end{array}$ & $\begin{array}{l}\text { Within } 2 \text { weeks } \\
\text { from injury. Open } \\
\text { reduction for graft } \\
\text { group and closed re- } \\
\text { duction for plaster } \\
\text { cast and external fix- } \\
\text { ation groups. Im- } \\
\text { mobilisation for } 6 \\
\text { weeks. }\end{array}$ & $\begin{array}{l}\text { Bone graft. } \\
\text { Open reduction and } \\
\text { bone graft (from il- } \\
\text { iac crest) held by } 1 \\
\text { Kirschner wire, then } \\
\text { forearm cast for } 6 \\
\text { weeks }\end{array}$ & $\begin{array}{l}\text { (1) Closed reduc- } \\
\text { tion and plaster cast } \\
\text { for } 6 \text { weeks. } \\
\text { or } \\
\text { (2) Open incisions } \\
\text { for pin insertion. } \\
\text { Bridging of radio- } \\
\text { carpal joint. Pennig } \\
\text { external fixator for } \\
6 \text { weeks. Ball joint }\end{array}$ \\
\hline
\end{tabular}


Table 5. Key characteristics of participants, fractures and interventions (Continued)

\begin{tabular}{|c|c|c|c|c|c|}
\hline & & & & & $\begin{array}{l}\text { released for limited } \\
\text { wrist motion in } 30 \\
\text { patients at } 3 \text { weeks. }\end{array}$ \\
\hline Rajan 2006 & $\begin{array}{l}93 ; \quad 81 \% \text { female; } \\
\text { mean age } 61 \text { years. }\end{array}$ & $\begin{array}{l}\text { Unstable fracture ei- } \\
\text { ther primarily or re- } \\
\text { displaced. Instabil- } \\
\text { ity defined if at least } \\
2 \text { criteria met: dorsal } \\
\text { angulation > } 20 \text { de- } \\
\text { grees, loss of radial } \\
\text { length > } 10 \mathrm{~mm} \text {, in- } \\
\text { tra-articular exten- } \\
\text { sion of fracture, se- } \\
\text { vere dorsal meta- } \\
\text { physeal comminu- } \\
\text { tion, radioulnar sep- } \\
\text { aration. AO types } \\
\text { A3, C2 and C3 (ex- } \\
\text { tra- and intra-artic- } \\
\text { ular) }\end{array}$ & $\begin{array}{l}\text { Pri- } \\
\text { mary or secondary } \\
\text { fixation at mean } 5.5 \\
\text { days from injury. } \\
\text { Open reduction and } \\
\text { dorsal plate fixation. } \\
\text { Dorsal splint then } \\
\text { full forearm cast for } \\
4 \text { weeks. }\end{array}$ & $\begin{array}{l}\text { Bone graft } \\
\text { Allogenic bone- } \\
\text { graft substitute (Tu- } \\
\text { toplast cancel- } \\
\text { lous chips). Dorsal } \\
\text { splint, then circular } \\
\text { forearm cast for } 4 \\
\text { weeks. }\end{array}$ & $\begin{array}{l}\text { Bone graft } \\
\text { Autogenic } \\
\text { bone-graft (from il- } \\
\text { iac crest). Dorsal } \\
\text { splint, then circular } \\
\text { forearm cast for } 4 \\
\text { weeks. }\end{array}$ \\
\hline $\begin{array}{l}\text { Sanchez-Sotelo } \\
2000\end{array}$ & $\begin{array}{l}110 ; 88 \% \text { female; } \\
\text { mean age } 66 \text { years. }\end{array}$ & $\begin{array}{l}\text { AO: A3 (extra-artic- } \\
\text { ular)or C2 (intra-ar- } \\
\text { ticular)distal radius } \\
\text { fractures. }\end{array}$ & $\begin{array}{l}\text { Soon after injury. } \\
\text { Closed reduction. } \\
\text { Duration of immo- } \\
\text { bilisation differed in } \\
\text { the two groups. }\end{array}$ & $\begin{array}{l}\text { Bone sub- } \\
\text { stitute. Debris etc } \\
\text { removed through } 1 \\
\mathrm{~cm} \text { incision and No- } \\
\text { rian SRS (calcium- } \\
\text { phosphate bone ce- } \\
\text { ment) injected into } \\
\text { cavity. Below-elbow } \\
\text { cast for } 2 \text { weeks. }\end{array}$ & $\begin{array}{l}\text { Below-elbow cast } \\
\text { for } 6 \text { weeks. }\end{array}$ \\
\hline Schmalholz 1989 & $\begin{array}{l}\text { 49; all female; mean } \\
\text { age } 68 \text { years. }\end{array}$ & $\begin{array}{l}\text { Redisplaced closed } \\
\text { unstable extra-artic- } \\
\text { ular distal ra- } \\
\text { dial fracture (dorsal } \\
\text { angulation } 30+\text { de- } \\
\text { grees and / or ax- } \\
\text { ial compression } 5 \\
\mathrm{~mm} \text { ) following sec- } \\
\text { ond closed manipu- } \\
\text { lation. }\end{array}$ & $\begin{array}{l}\text { Varied, } 8 \text { to } 24 \text { days } \\
\text { af- } \\
\text { ter initial closed re- } \\
\text { duction for trial en- } \\
\text { try. Open reduction } \\
\text { at } 14-24 \text { days post } \\
\text { fracture for bone } \\
\text { cement group and } \\
\text { closed reduction } 15- \\
24 \text { days from plaster } \\
\text { cast group. } \\
\text { Duration of immo- } \\
\text { bilisation differed in } \\
\text { the two groups. }\end{array}$ & $\begin{array}{l}\text { Bone substitute. } \\
\text { Open reduction and } \\
\text { methylmethacry- } \\
\text { late cement used to } \\
\text { fill dorsal bone defi- } \\
\text { ciency. Dorsal plas- } \\
\text { ter for } 2 \text { weeks. }\end{array}$ & $\begin{array}{l}\text { Closed reduc- } \\
\text { tion and below-el- } \\
\text { bow plaster cast: for } \\
4 \text { weeks. }\end{array}$ \\
\hline Schmalhotz 1990 & $\begin{array}{l}50 ; 96 \% \text { female; } \\
\text { median age } 66-67\end{array}$ & $\begin{array}{l}\text { Redisplaced closed } \\
\text { unstable distal ra- }\end{array}$ & $\begin{array}{l}\text { Var- } \\
\text { ied, } 14 \text { to } 18 \text { days }\end{array}$ & $\begin{array}{l}\text { Bone substitute. } \\
\text { Open reduction and }\end{array}$ & $\begin{array}{l}\text { External fixation - } 2 \\
\text { pins in }\end{array}$ \\
\hline
\end{tabular}


Table 5. Key characteristics of participants, fractures and interventions (Continued)

\begin{tabular}{|c|c|c|c|c|c|}
\hline & years. & $\begin{array}{l}\text { dial fracture (dorsal } \\
\text { angulation } 30+\text { de- } \\
\text { grees and / or ax- } \\
\text { ial compression } 5 \\
\text { mm) following sec- } \\
\text { ond closed manipu- } \\
\text { la- } \\
\text { tion. Frykman type } \\
\text { I and II fractures: ex- } \\
\text { tra-articular. }\end{array}$ & $\begin{array}{l}\text { post injury. Open } \\
\text { reduction for graft } \\
\text { group and closed re- } \\
\text { duction for external } \\
\text { fixator group. Dura- } \\
\text { tion of immobilisa- } \\
\text { tion differed in the } \\
\text { two groups. }\end{array}$ & $\begin{array}{l}\text { methylmethacry- } \\
\text { late cement used to } \\
\text { fill dorsal bone defi- } \\
\text { ciency. Dorsal plas- } \\
\text { ter for } 2 \text { weeks. }\end{array}$ & $\begin{array}{l}\text { 2nd metacarpal and } \\
2 \text { in radial shaft) } \\
\text { with one bar Hoff- } \\
\text { man fixator for } 33 \text { to } \\
40 \text { days (5-6 weeks). }\end{array}$ \\
\hline Widman 2002 & $\begin{array}{l}48 ; 69 \% \text { female; } \\
\text { mean age } 51.5 \text { years. }\end{array}$ & $\begin{array}{l}\text { Severely } \\
\text { displaced and com- } \\
\text { minuted distal ra- } \\
\text { dial fracture, Older } \\
\text { type } 3 \text { (radial sty- } \\
\text { loid process short- } \\
\text { ened > } 4 \text { mm dis- } \\
\text { tal to ulna) or type } 4 \\
\text { (marked comminu- } \\
\text { tion and radial sty- } \\
\text { loid process short- } \\
\text { ened to level of ulna } \\
\text { or less). Older types } \\
3 \& 4 \text {; AO types A2, } \\
\text { A3, C1, C2, C3 (ex- } \\
\text { tra-articular and in- } \\
\text { tra-articular). }\end{array}$ & $\begin{array}{l}\text { After treatment at } \\
\text { A\&E department. } \\
\text { Closed and open re- } \\
\text { duction under gen- } \\
\text { eral anesthesia for } \\
\text { bone graft group } \\
\text { and closed reduc- } \\
\text { tion under regional } \\
\text { anaesthesia for con- } \\
\text { trol group. } \\
\text { Duration of immo- } \\
\text { bilisation differed in } \\
\text { the two groups. }\end{array}$ & $\begin{array}{l}\text { Bone graft. } \\
\text { External fix- } \\
\text { ation (using a half- } \\
\text { frame Hoffman ex- } \\
\text { ternal fixator: } 2 \text { pins } \\
\text { in 2nd metacarpal } \\
\text { and } 2 \text { in radial shaft) } \\
\text { and cancellous bone } \\
\text { graft } \\
\text { (from iliac crest) in- } \\
\text { serted through } 3- \\
4 \text { cm dorsal inci- } \\
\text { sion into fracture } \\
\text { cavity. External fix- } \\
\text { ator for } 3 \text { weeks, } \\
\text { then plaster cast, al- } \\
\text { lowing volar flexion } \\
\text { but limited exten- } \\
\text { sion, for } 3 \text { weeks. }\end{array}$ & $\begin{array}{l}\text { External fixation } \\
\text { alone. Removed af- } \\
\text { ter } 6 \text { weeks. }\end{array}$ \\
\hline
\end{tabular}

Bone scaffolding alone versus conservative interventions such as plaster cast immobilisation

\section{Bone scaffolding - bone graft/substitute - versus conservative treatment}

Four trials (Kopylov 2002; McQueen 1996; Sanchez-Sotelo 2000; Schmalholz 1989) compared the insertion of bone scaffolding material into the radial metaphyseal defect with plaster cast immobilisation alone in 239 people. Three trials (Kopylov 2002; McQueen 1996; Schmalholz 1989) recruited patients with fractures that had redisplaced while Sanchez-Sotelo 2000 involved primary treatment of acute fractures. Schmalholz 1989 included only extra-articular fractures. The bone scaffolding material was autogenous bone graft fixed by a Kirschner wire in McQueen 1996, a calcium-phosphate bone cement marketed under the name Norian SRS (Norian skeletal repair system) in Kopylov 2002 and Sanchez-Sotelo 2000, and methylmethacrylate cement in Schmalholz 1989. In contrast to the two other trials of redisplaced fractures (McQueen 1996; Schmalholz 1989), no re-reduction was performed for conservatively treated patients in Kopylov 2002. Post-operative immobilisation lasted six weeks in McQueen 1996, one week in Kopylov 2002 and two weeks in the other two trials. The duration of immobilisation in the conservative treatment group was one week in Kopylov 2002, four weeks in Schmalholz 1989, and six weeks in two trials (McQueen 1996; 
Schmalholz 1989).

Bone substitute versus "conventional" treatment (plaster cast or external fixation)

This comparison has been added to accommodate Cassidy 2003, which compared the insertion of bone scaffolding material (Norian SRS) into the radial metaphyseal defect in 161 people versus "conventional" treatment of either a plaster cast (108 people) or external fixation (54 people). Though the stratification at randomisation in Cassidy 2003 may have allowed the splitting up of the results into two comparisons ('Bone scaffolding - bone graft/ substitute - versus conservative treatment; Bone scaffolding - bone graft or substitute - versus external fixation"), this was not possible here. Cassidy 2003 included acute fractures only. Post-operative immobilisation in the bone scaffolding group was two weeks compared with six to eight weeks in the control group. Percutaneous wiring was used for fracture fixation in $40 \%(64 / 161)$ of the bone substitute group and 51\% (82/162) of the control group.

Bone scaffolding with surgical fixation versus the same method of surgical fixation alone

\section{Bone graft, external fixation then plaster cast versus external fixation}

One trial (Widman 2002) evaluated the filling of the bone defect with an autogenous bone graft in the context of external fixation in 48 people. However, the interventions allocated to the two groups in Widman 2002 also differed in other important ways. Application of an external fixator, reduction under fluoroscopic control, bone grafting and open reduction of displaced fragments were performed under general anaesthesia in one group. In this group, the external fixator was removed after three weeks and replaced by a plaster cast allowing volar flexion (wrist could be bent downwards) for the following three weeks. In the other group, closed reduction and application of an external fixator were performed using intravenous regional anaesthesia; the fixator was removed after six weeks.

\section{Bone scaffolding alone versus surgical fixation}

\section{Bone substitute versus percutaneous pinning}

One trial (Jeyam 2002) compared the insertion of hydroxyapatite bone cement in the bone cavity versus Kapandji's intrafocal pinning using two or three wires in 21 older women with intra-articular fractures.

\section{Bone scaffolding - bone graft or substitute - versus external} fixation

Three trials (Kopylov 1999; McQueen 1996; Schmalholz 1990) compared the insertion of bone scaffolding material into the radial metaphyseal defect with external fixation in 180 people. All three trials recruited patients with redisplaced fractures. Schmalholz 1990 included only extra-articular fractures. The bone scaffolding material was autogenous bone graft fixed by a Kirschner wire in McQueen 1996, a calcium-phosphate bone cement (Norian SRS) in Kopylov 1999, and methylmethacrylate cement in Schmalholz 1990. Post-operative immobilisation in the bone scaffolding group was the same as the external fixator group in McQueen 1996 but only two weeks in the other two trials compared with removal of the external fixators at times between five and six weeks.

\section{Comparisons of different types of bone scaffolding}

\section{Allografts versus autografts}

One trial (Rajan 2006) compared allogenic bone-graft substitute (cancellous chips) versus autogenic bone-graft (from iliac crest) in 93 people undergoing primary or secondary open reduction and dorsal plate fixation.

\section{Excluded studies}

Six studies were excluded for reasons stated in the 'Characteristics of excluded studies'. These reasons were: lack of separate data for distal radial fractures ( 2 trials), trial not started (1 trial), no clinically relevant outcomes ( 1 trial), unable to obtain trial report ( 1 trial) and comparison not included in this review (1 trial)

\section{Ongoing studies}

Details of the one ongoing study (Barbier 2008) are presented in the 'Characteristics of ongoing studies'.

\section{Studies awaiting assessment}

There are no studies awaiting assessment.

\section{Risk of bias in included studies}

The quality of trial methodology, judged using the 11 quality criteria listed in Table 3, is somewhat disappointing. Associated with this is a high potential for the key systematic biases (selection, performance, assessment and attrition) leading to questions about internal validity, and issues of clinical relevance and applicability or external validity. These will be considered further in the 'Discussion'. The results, together with some notes on specific aspects, of the quality assessment for the individual trials are shown in 
Table 6. Information specific to the first three items of the quality assessment is given in the methods sections of the 'Characteristics of included studies'. A summary of the results for individual items of quality assessment is given below.

Table 6. Quality assessment results for individual trials (see Table 04 for scheme)

\begin{tabular}{|c|c|c|c|c|}
\hline Study ID & Items and grades & Items and grades & Items and grades & Notes \\
\hline Study ID & $\begin{array}{l}\text { Item 1: Allocation con- } \\
\text { cealment Item 2: In- } \\
\text { tention-to-treat analysis } \\
\text { Item 3: Outcome assessor } \\
\text { blinding Item 4: Compa- } \\
\text { rable baseline characteris- } \\
\text { tics }\end{array}$ & $\begin{array}{l}\text { Item 5: Participant blind- } \\
\text { ing Item 6: Treatment } \\
\text { provider blinding Item } \\
\text { 7: Identical care pro- } \\
\text { grammes Item 8: Clearly } \\
\text { defined inclusion criteria }\end{array}$ & $\begin{array}{l}\text { Item 9: Well defined out- } \\
\text { come measures Item 10: } \\
\text { Optimal outcome assess- } \\
\text { ment Item 11: Optimal } \\
\text { timing of follow up (> } 1 \\
\text { year) In brackets: date of } \\
\text { last follow up; \% lost to } \\
\text { last follow up }\end{array}$ & $\begin{array}{l}\text { Comments and explana- } \\
\text { tions for specific items }\end{array}$ \\
\hline Cassidy 2003 & ?, $\mathrm{Y}, \mathrm{N}$, ? & $\mathrm{N}, \mathrm{N}, \mathrm{N}, \mathrm{Y}$ & Y, Y, ? (1 year; 9\%) & $\begin{array}{l}\text { Item 4: there were signif- } \\
\text { icantly }(\mathrm{P}=0.04) \text { more } \\
\text { females in the control } \\
\text { group. } \\
\text { Item 7: There was an ab- } \\
\text { sence of data on care pro- } \\
\text { grammes. Also an imbal- } \\
\text { ance in the use of supple- } \\
\text { mental wires ( } 40 \% \text { versus } \\
51 \%)\end{array}$ \\
\hline Jeyam 2002 & ?, ?, N, ? & $\mathrm{N}, \mathrm{N}, ?, \mathrm{Y}$ & ?, ?, ? (6 months; $14 \%)$ & $\begin{array}{l}\text { Items } 2 \text { and } 4: \text { data } \\
\text { were missing for three ex- } \\
\text { cluded patients ( } 2 \text { died; } 1 \\
\text { had wrong operation). }\end{array}$ \\
\hline Kopylov 1999 & ?, Y, N, Y & $\mathrm{N}, \mathrm{N}, ?, \mathrm{Y}$ & Y, ?, ? (1 year; 5\%) & $\begin{array}{l}\text { Item 3: there was, how- } \\
\text { ever, some independent } \\
\text { checking of data col- } \\
\text { lection and independent } \\
\text { evaluation by a radiolo- } \\
\text { gist and a physiotherapist }\end{array}$ \\
\hline Kopylov 2002 & ?, Y, N, Y & $\mathrm{N}, \mathrm{N}, \mathrm{Y}, \mathrm{Y}$ & $\mathrm{Y}$, ?, ? (6 months; $0 \%)$ & $\begin{array}{l}\text { Item 3: there was, how- } \\
\text { ever, some independent } \\
\text { checking of data collec- } \\
\text { tion and potentially inde- } \\
\text { pendent evaluation by a } \\
\text { physiotherapist and radi- } \\
\text { ologist. } \\
\% \text { loss to follow up: the } \\
\text { two patients who refused }\end{array}$ \\
\hline
\end{tabular}


Table 6. Quality assessment results for individual trials (see Table 04 for scheme) (Continued)

\begin{tabular}{|c|c|c|c|c|}
\hline & & & & $\begin{array}{l}\text { to attend follow up were } \\
\text { contacted by phone. }\end{array}$ \\
\hline McQueen 1996 & ?, Y, N, ? & $\mathrm{N}, \mathrm{N}$, ?, Y & Y, ?, ? (1 year; 9\%) & $\begin{array}{l}\text { Item } 4 \text { : the bone graft pa- } \\
\text { tients were on average } 5 \\
\text { years younger than the ex- } \\
\text { ternal fixator or the con- } \\
\text { trol group patients. }\end{array}$ \\
\hline Rajan 2006 & $\mathrm{~N}, \mathrm{~N}, \mathrm{~N}, ?$ & N, N, Y, Y & Y, ?, ? (1 year; 0\%) & $\begin{array}{l}\text { Item 1: quasi-randomised } \\
\text { trial based on date of ad- } \\
\text { mission } \\
\text { Item 2: results were not } \\
\text { given for } 3 \text { patients who } \\
\text { did not accept iliac crest } \\
\text { surgery for bone harvest- } \\
\text { ing; not clear if there were } \\
\text { any withdrawals }\end{array}$ \\
\hline Sanchez-Sotelo 2000 & ?, ?, N, Y & $\mathrm{N}, \mathrm{N}$, ?, Y & $\mathrm{Y}$, ?, ? (1 year; 0\%?) & $\begin{array}{l}\text { Item 2: not clear if there } \\
\text { were any losses to follow } \\
\text { up }\end{array}$ \\
\hline Schmalholz 1989 & $\mathrm{~N}, ?, \mathrm{~N}, \mathrm{Y}$ & $\mathrm{N}, \mathrm{N}, \mathrm{N}, \mathrm{Y}$ & Y, ?, Y (2 years; 4\%?) & $\begin{array}{l}\text { Item 1: quasi-randomised } \\
\text { trial based on date of } \\
\text { birth } \\
\text { Item } 7 \text { : different methods } \\
\text { of anaesthesia }\end{array}$ \\
\hline Schmalholz 1989 & $\mathrm{~N}, ?, \mathrm{~N}, ?$ & $\mathrm{~N}, \mathrm{~N}$, ?, Y & $\begin{array}{l}\mathrm{Y} \text {, ?, Y (1 year after fixator } \\
\text { removal; } 4 \% \text { ?) }\end{array}$ & $\begin{array}{l}\text { Item 1: quasi-randomised } \\
\text { trial based on date of } \\
\text { birth } \\
\text { Item 7: different numbers } \\
\text { had physiotherapy in the } \\
2 \text { groups }\end{array}$ \\
\hline Widman 2002 & ?, ?, N, Y & $\mathrm{N}, \mathrm{N}, \mathrm{N}, \mathrm{Y}$ & Y, ?, ? (1 year; 6\%) & $\begin{array}{l}\text { Item } 7 \text { : including differ- } \\
\text { ences in anaesthesia and } \\
\text { no information on post- } \\
\text { immobilisation care }\end{array}$ \\
\hline
\end{tabular}

\section{Allocation concealment (item 1)}

No trial was considered to have satisfied the criteria for secure allocation concealment, which in some trials may reflect an insufficiently reported randomisation process. The one trial (Jeyam 2002) that seemed to fulfil the criteria (numbered, opaque and sealed envelopes) was revealed in a commentary (McKee 2003) not to have been "fully concealed". Envelopes were also used in three other trials (Kopylov 1999; Kopylov 2002; McQueen 1996).
Treatment assignment was computer generated in Cassidy 2003 and based on random numbers table in Widman 2002. SanchezSotelo 2000 provided no details on the method of randomisation. The three remaining trials used quasi-randomised methods based on date of admission (Rajan 2006) or dates of birth (Schmalholz 1989; Schmalholz 1990).

Intention-to-treat analysis (item 2) 
Clear statements of participant flow with evidence of intentionto-treat analysis, together with consistent reporting, were available for four trials (Cassidy 2003; Kopylov 1999; Kopylov 2002; McQueen 1996). Rajan 2006 had an 'N' rating because of the exclusion from the analyses of patients who refused bone harvesting and the lack of clarity on participant flow.

\section{Blinding of outcome assessors (item 3)}

No trial blinded outcome assessors. However, while not rated, three trials (Kopylov 1999; Kopylov 2002; Rajan 2006) referred to some independent assessment or data checks. Total blinding of outcome assessment is impractical for trials testing surgical interventions but it is possible for some outcomes and more so at longer-term follow up.

\section{Comparability of baseline characteristics (item 4)}

Five trials (Kopylov 1999; Kopylov 2002; Sanchez-Sotelo 2000; Schmalholz 1990; Widman 2002) provided sufficient information indicating the similarity in the baseline characteristics of gender, age and type of fracture. Potentially important imbalances in gender (Cassidy 2003) and age (McQueen 1996) between the two treatment groups were reasons for a '?' rating for these two trials.

\section{Blinding of patients and treatment providers (items 5 and 6)}

These are unlikely in these studies and none was claimed.

\section{Care programme comparability (item 7)}

We found it difficult to confirm comparability of care programmes, including surgical experience, other than the trial interventions. Nonetheless, we judged it highly likely in Kopylov 2002 and Rajan 2006.

\section{Description of inclusion criteria (item 8)}

All the included trials were considered to have provided sufficient trial inclusion and exclusion criteria to define their study populations.

Definition and quality of outcome measurement (items 9 and 10)

Outcome measurement was sufficiently well described in all of the included trials except Jeyam 2002. Only Cassidy 2003 was rated as having 'optimal' quality outcome measurement, which included use of validated patient assessed quality of life instruments and active follow up. The variety of outcome measures reported by the trials is evident from inspection of the 'Characteristics of included studies'.

\section{Length of follow up (item 11)}

Follow up ranged from six months (Jeyam 2002; Kopylov 2002) to two years (Schmalholz 1989).

\section{Loss to follow up (not rated)}

The highest reported loss to final follow up was $14 \%$ at six months in Jeyam 2002. For some of the trials appearing to have no losses, it may be the case that these were not reported.

\section{Effects of interventions}

In the following, two comparisons featured trials that tested different bone scaffolding materials versus either plaster cast immobilisation alone or external fixation. The data available for pooling for both comparisons were limited and pooling was further restricted in the light of significant statistical heterogeneity. Formal subgroup analyses by bone scaffolding material for indirect comparisons was inappropriate.

Bone scaffolding alone versus conservative interventions such as plaster cast immobilisation

Bone scaffolding - bone graft/substitute - versus conservative treatment

Four trials compared the use of a bone graft (McQueen 1996) or bone substitutes (Kopylov 2002 and Sanchez-Sotelo 2000: Norian SRS; Schmalholz 1989: methylmethacrylate cement) with plaster cast immobilisation alone in 239 mainly older and female patients. Three trials (Kopylov 2002; McQueen 1996; Schmalholz 1989) recruited patients whose fractures had redisplaced. Schmalholz 1989 only included extra-articular fractures. Importantly, the redisplaced fractures of control group patients were not re-reduced in Kopylov 2002. Further details, revealing other differences, of the trials are provided in Table 5.

The data presented for grip strength and range of motion (see Analyses 01.03 and 01.07) for the two groups of McQueen 1996 were consistent with the conclusion of no significant difference in functional results stated in the trial report. No difference between the two groups in the patients' rating of impairment of hand function was also reported, but without supporting data, in Kopylov 2002. Kopylov 2002 reported that the small differences between the two groups in mean grip strength (at six months: $70 \%$ versus $72 \%$ relative to the contralateral arm) and mobility were not statistically significant at any of the follow-up times. Both functional scoring systems used by Sanchez-Sotelo 2000 and Schmalholz 1989 rated deformity and, for Schmalholz 1989, various complications. Superior functional grades were obtained in the bone substitute group in these two trials, with significantly more bone substitute group patients obtaining excellent or good results (see Analysis 01.01). The results for fair or poor functional gradings in the two trials were markedly different $\left(\mathrm{I}^{2}=81.8 \%\right)$ although favouring the bone scaffolding groups in both trials. Though these data are not pooled, it should be noted that pooling using the randomeffects model yields a statistically non-significant result (Fair or poor functional grading: relative risk (RR) $0.16,95 \%$ confidence interval (CI) 0.02 to 1.65 ). These results reflected the better grip strength and range of motion in the bone substitute group of both trials (see Analyses 01.03, 01.06, 01.07). Though assessed there were no pain results given in McQueen 1996. There was no sig- 
nificant difference between the two groups in the mean visual analogue pain scores, both low, at six months in Kopylov 2002 (see Analyses 01.04 ). There were statistically significantly more people experiencing pain in the control groups of Sanchez-Sotelo 2000 and Schmalholz 1989 (see Analysis 01.05).

Complications suffered by the participants of the four trials are presented in Analysis 01.08. There were no statistically significant differences between the two groups in most complications (e.g. carpal tunnel syndrome, tendon rupture, infection, RSD). However, recurrent instability was found statistically significantly more often in the conservative treatment group of McQueen 1996 (3/30 versus $16 / 30$; RR $0.19,95 \%$ CI 0.06 to 0.58 ), and likewise, displacement requiring secondary treatment occurred in the majority (38/55) of conservatively treated participants of Sanchez-Sotelo 2000. But, the first observation should be moderated by the overcorrection or further collapse of volar tilt in seven bone graft wrists in McQueen 1996. Similarly, the same number (38/55) of bone substitute patients in Sanchez-Sotelo 2000 had soft-tissue deposits of bone cement, many of which gave transient discomfort. Eighteen of these were still present at follow up. Another deposit within the joint had to be removed surgically. Kopylov 2002 did not report the long-term outcome of the three bone substitute patients whose post-operative pain was attributed to soft-tissue extrusion of bone cement. Schmalholz 1989 reported that the bone cement was surrounded by cortical bone in all cases. McQueen $1996 \mathrm{did}$ not report on donor-site complications.

In Sanchez-Sotelo 2000, most of the conservatively treated fractures redisplaced requiring remanipulation and a new plaster cast $(38 / 55)$. Further fracture displacement occurred in both groups of Kopylov 2002; this was, however, from different starting positions since re-reduction was only done in the bone substitute group. At six months, anatomical measurements were indicated as being statistically significantly better in the operative group of Kopylov 2002 (mean dorsal angle: 6 versus 24 degrees; mean ulnar variance: $2 \mathrm{~mm}$ versus $4 \mathrm{~mm}$ ). Superior long-term anatomical results in the bone scaffolding group were also reported in the other three trials. The differences between the operative and control groups in the retention of the restored (Sanchez-Sotelo 2000) or improved ( Schmalholz 1989) dorsal angulation after reduction were statistically significant. This is shown in Analysis 01.10, and reported by Sanchez-Sotelo 2000 (mean volar angle: 3.6 versus -3.2 degrees; $\mathrm{P}<0.01$ ). The mean radial shortening was reported to be statistically significantly lower in Sanchez-Sotelo 2000 (mean radial shortening: $3.8 \mathrm{~mm}$ versus $6.1 \mathrm{~mm} ; \mathrm{P}<0.01$ ) and Schmalholz 1989 (1.38 $\mathrm{mm}$ versus $5.61 \mathrm{~mm}$ ) but no difference was found in McQueen 1996 (see Analysis 01.09 ). Data for these anatomical outcomes were not pooled given the highly significant heterogeneity $\left(\mathrm{I}^{2}=96.7 \%\right.$ and $90.2 \%$ respectively for Analyses 01.09 and 01.10). Mean losses in ulnar variance $(0.77 \mathrm{~mm}$ versus $2.44 \mathrm{~mm})$ and increases in radial width $(0.58 \mathrm{~mm}$ versus $1.35 \mathrm{~mm})$ were also reported to be statistically significant by Sanchez-Sotelo 2000 . These results were reflected by the significantly greater numbers of wrists meeting the criteria for malunion in the conservative treatment groups of McQueen 1996 and Sanchez-Sotelo 2000 (see Analysis 01.11: 20/85 versus 43/85; RR $0.47,95 \%$ CI 0.30 to $0.71)$; and in the numbers of people ( $0 / 24$ versus $15 / 23)$ who were dissatisfied with the appearance of their wrist at long-term follow up in Schmalholz 1989 (see Analysis 01.11). Most patients accepted their wrist deformity in Kopylov 2002, however, one control group patient with a painful malunion requested and underwent a corrective osteotomy at eight months. There was no significant difference between the two groups of McQueen 1996 in the numbers of people with carpal collapse (11/30 versus 14/30). Bone substitute versus "conventional” treatment (plaster cast or external fixation)

Cassidy 2003 compared the insertion of bone substitute (Norian SRS bone cement) into the radial metaphyseal defect with immobilisation in a plaster cast or external fixator in 323, mainly older and female patients with acute extra-articular or intra-articular fractures. Supplementary percutaneous wiring was used in 146 people, spread over the two groups. Post-operative immobilisation was two weeks in the bone substitute versus six to eight weeks in the control group. The following account of the results of this trial incorporates the results from the two key reports of the trial; the earlier one (FDA 1998) being produced through the Federal Drug Agency (USA).

Data were not available for the various quality of life and hand function measures collected in Cassidy 2003, which reported that while early findings, before eight weeks, significantly favoured the bone substitute group, there were no differences between the groups at one year. Based on the presence of unsuccessful (more than $10 \%$ difference from normal side) individual outcomes of functional impairment, only two participants, both of the bone substitute group, were considered in the FDA report to have an unsuccessful functional outcome (see Analysis 02.01). However, this seems inconsistent with the results for grip strength, the primary functional outcome in this trial, where both groups had mean discrepancies of over 10\% (see Analysis 02.02: RR -0.60\%, 95\% CI $-6.31 \%$ to $5.11 \%$ ). Significantly fewer participants of the bone substitute group reported pain at two and four weeks after their treatment (reported $\mathrm{P}=0.02$ ) and required less post-operative pain medication. There was, however, no significant difference between the two groups in pain (listed under complications) at one year follow up (see Analysis 02.03: 4/161 versus 10/162; RR 0.40, 95\% CI 0.13 to 1.26 ). There were no significance differences between the two groups in range of motion outcomes (see Analysis 02.04). Again, the results presented in FDA 1998 for the very few people with motion deficits above $10 \%$ (see Analysis 02.05 ) seem at odds with the data in Analysis 02.04 .

The complications suffered by the participants of Cassidy 2003 are presented in Analysis 02.06. Marginally fewer participants of the bone substitute group experienced one or more complication (74/161 versus 82/162; RR 0.91, 95\% CI 0.72 to 1.14 ). However, aside from four people with intra-articular deposits, people with 
initial $(112 / 161 ; 70 \%)$ or persistent $(29 / 161 ; 18 \%)$ extraosseous deposits of bone cement, which may have caused some discomfort, were not included in these figures. The significant excess of infection in the conventional treatment group (3/161 versus $25 / 162$; RR $0.12,95 \%$ CI 0.04 to 0.39 ) was due to pin track infections in patients with external fixators; these were of undefined diagnosis and outcome. No other differences between the two groups reached statistical significance. Cassidy 2003 observed that the total number of complications were significantly lower for bone substitute group participants without extraosseous material compared to those with extraosseous material.

The difference between the two groups in the average loss in radial length, the primary radiological outcome in Cassidy 2003, was not statistically significant (see Analysis 02.07). Similarly, there were no differences for radial or dorsal angulation. As reported in FDA 1998, similar numbers in the two groups had an unsuccessful radiological outcome overall (see Analysis 02.08: 71/133 versus 66/138; RR 1.12, 95\% CI 0.88 to 1.41 ). However, more participants of the bone substitute had a substantial change in dorsal angulation (see Analysis 02.08), and notably significantly more had a dorsal angle of over 10 degrees (see Analysis 02.08: 42/133 versus 28/136; RR 1.53, 95\% CI 1.01 to 2.32). Again, the results presented in FDA 1998 seem at odds with those in Cassidy 2003 (see Analysis 02.07). The patients in the latter group would have been considered to have a malunion in similar studies (McQueen 1996; Sanchez-Sotelo 2000).

Bone scaffolding with surgical fixation versus the same method of surgical fixation alone

Bone graft, external fixation then plaster cast versus external fixation

Widman 2002 compared the effects of bone grafting and replacing an external fixator after three weeks with a plaster cast, which allowed volar flexion, versus external fixation for six weeks in 48 people with severely displaced and comminuted fractures. At one year follow up, there were no significant differences between the two groups in those with considerable functional impairment (see Analysis 03.01) or in the grip strength and range of movement relative to the normal side (see Analyses 03.02 and 03.03). The few complications reported are presented in Analysis 03.04. Surgery was required to resolve one case of deep pin-track infection and one case with carpal tunnel syndrome in the control group. Surgery was also undertaken for the single case of superficial painful granuloma in the bone graft group. A serious bleed at the donor site for the bone graft ceased after compression. It is possible that more minor donor site complications were not reported in Widman 2002. There were no significant differences between the two groups in anatomical measurements (see Analysis 03.05) or in the numbers with malunion (see Analysis 03.05).

Bone scaffolding alone versus surgical fixation

Bone substitute versus percutaneous pinning

Jeyam 2002 compared the use of bone substitute (hydroxyapatite cement) with Kapandjis intrafocal pinning in 21 older women with intra-articular fractures. Data were unavailable for two people who died and one who was treated with a non-standard Kapandji technique. At six months follow up, the mean loss in grip strength relative to the patient's uninjured hand was reported to be statistically significantly greater in the bone substitute group (mean loss: 44\% versus 27\%). There was little difference reported for range of movement parameters at six months follow up except for palmar flexion, which was significantly less in the bone substitute group (see Analysis 04:01: mean difference -10.00 degrees, $95 \%$ CI -18.89 to -1.11 degrees). No complications occurred in either group. Dorsal angulation was reported to be statistically significantly worse in the bone substitute group (median 10 versus 4 degrees; $\mathrm{P}<0.02$ ), but the differences between the two groups in radial angle and ulnar variance were slight and reported not to be statistically significant. None of the participants took up the offer of a revision procedure for malunion.

Bone scaffolding - bone graft or substitute - versus external fixation

Three trials compared the use of autogenous bone graft (McQueen 1996) or different bone substitutes (Kopylov 1999: Norian SRS; Schmalholz 1990: methylmethacrylate cement) versus external fixation in 180 mainly older and female patients with redisplaced fractures. Schmalholz 1990 only included extra-articular fractures. Further details of these trials that show the differences in the trial populations and interventions are provided in Table 5. Aside from some complications, no pooling of data was possible for the various outcome measures reported for these trials.

Where functional outcome and impairment were reported, all three trials found no statistically significant differences between the two groups at one year follow up. This was evident for overall functional grades, which also rated deformity, in Schmalholz 1990 (see Analysis 05.01); for grip strength in Schmalholz 1990 (see Analyses 05.02) and McQueen 1996 (see Analysis 05.03); for pain (see Analysis 05.04); and range of motion outcomes (see Analyses 05.05 and 05.06). Kopylov 1999 reported a significantly earlier recovery in the bone substitute group of grip strength (mean grip strength at 7 weeks: $108 \mathrm{~N}$ versus $65 \mathrm{~N}$ ) and range of motion: extension (43 versus 27 degrees) and supination (69 versus 53 degrees) at seven weeks. Similar findings of an earlier regain of function in the bone substitute group were reported by Schmalholz 1990; in both bone substitute trials these findings reflect the constriction of movement during external fixation. For instance, eight patients in Schmalholz 1990 were unable to clench their fist on removal of the fixator around five to six weeks whereas all people in the bone substitute group could clench their fists at all times. Complications suffered by the participants of the three trials are presented in Analysis 05.07. The majority of complications or complaints were associated with external fixation. Though there were no statistically significant differences between the two groups in common complications such as carpal tunnel syndrome, tendon rupture and RSD, there was a notable excess of patients in the external fixator group with RSD in McQueen 1996; and of trial 
participants with swollen wrists and persistent finger stiffness in Kopylov 1999. Seven of the eight people in Schmalholz 1990 had early problems with finger movements after the removal of their external fixator had no problems two weeks later. Although recurrent instability was found statistically significantly more often in the external fixation group in McQueen 1996, this finding should be moderated by the over-correction or further collapse of volar tilt in seven bone graft wrists. The incidence of extraosseous deposits of bone cement was not quantified by Kopylov 1999; however it was suggested that the tendon rupture in the bone substitute group could have resulted from attrition by the bone cement. Schmalholz 1990 reported that the bone cement was surrounded by cortical bone in all cases. McQueen 1996 did not report on donor-site complications.

Retention of reduced dorsal angulation was superior in the bone graft group in McQueen 1996 (see Analysis 05.09, but there were no statistically significant differences between the two groups in radial shortening, malunion or carpal collapse (see Analyses 05.08 and 05.11). There was a "mild loss of fracture reduction over time" in Kopylov 1999: radial angle (4 versus 1 degrees); dorsal angle (4 versus 0.5 degrees); ulnar variance $2.7 \mathrm{~mm}$ versus $1.3 \mathrm{~mm}$ ). Only the difference in the loss in ulnar variance reached statistical significance; the loss being higher in the bone substitute group. However, the bone substitute group started with a better initial reduced position, stated as being due to open rather than closed reduction, and the two groups ended up with similar anatomical results. Increases in dorsal angulation and radial shortening after treatment occurred in marginally more external fixator patients in Schmalholz 1990 but this was not statistically significant (see Analysis 05.10). Dissatisfaction with wrist appearance resolved quicker in the bone substitute group but the two people in the external fixator group who were dissatisfied at three months did not register a complaint at six months (see Analysis 05.11).

Comparisons of different types of bone scaffolding Allografts versus autografts

One trial (Rajan 2006) compared allogenic bone-graft substitute (cancellous chips) versus autogenic bone-graft (from iliac crest) in 93 people undergoing primary or secondary open reduction and dorsal plate fixation. Data were unavailable for three people who refused bone harvesting. At one year follow up, similar numbers of participants in the two groups reported restrictions in everyday life resulting from their injury (see Analysis 06.01: 5/44 versus 6/46; RR $0.87,95 \%$ CI 0.29 to 2.65). Based on a functional assessment scheme that included consideration of deformity and complications (Gartland 1951), there were no statistically significant differences between the two groups in the numbers with either a non-excellent result or only a fair result (no participant had a poor result): see Analysis 06.02 .

The number of workers was not given but none failed to return to their previous work: the return to work took longer in the autograft group (11.1 weeks versus 16.2 weeks; statistical significance not stated). Recovery of grip strength tended to be better in the autograft group (see Analysis 06.03). There was no significant difference in the numbers with residual wrist pain (see Analysis 06.04: 4/44 versus $7 / 46$; RR $0.60,95 \%$ CI 0.19 to 1.90 ). Wrist mobility tended to be better in the autograft group, however, the differences between the groups were fairly small (see Analysis 06.05); no data for flexion were given in the trial report.

Aside from removal of plate because of limited wrist mobility, there were no other complications reported for the wrist surgery. However, there were many complications from the iliac crest harvesting in the autograft group. Half of these patients suffered post-operative pain, which was both intense and restricted mobility in 12 of these. The person who sustained a tear off of the anterior superior iliac spine was treated conservatively. Of the eight people who had an haematoma, one had an infection and two had a seroma that required drainage. At one year, six people had discomforting sensations, two of whom had complete loss of sensibility of the lateral upper thigh. Thirteen people still reported pain (six had discomforting pain) at one year from the iliac crest surgery. Similar numbers in the two groups indicated that they were dissatisfied with their outcome (see Analysis 06.07: 14/44 versus 18/46; RR 0.81, $95 \%$ CI 0.46 to 1.43 ). Consistent with the additional procedure, the surgery took 28 minutes longer in the supplementary pinning group (see Analysis 06.10). There was no difference between the two groups in the length of hospital stay (see Analysis 06.11).

\section{I S C U S S I O N}

While several of the main choices available for bone implantation after distal radial fracture in adults were addressed by the 10 randomised controlled trials (874 participants) included so far in this review, as we examine below no definite conclusions can be drawn from the available evidence. The two oldest trials ( Schmalholz 1989; Schmalholz 1990), conducted by the same investigator tested methylmethacrylate cement, a material which few nowadays would use for these fractures because it does not stimulate new bone growth and may indeed inhibit it (Carson 2007). There is a general view of the undesirability of the use of such biologically inert materials as well as the risk of thermal necrosis of the cellular components of host bone and the effect on healing (Mjoberg 1984). Thus, there is even less evidence available with the potential to inform current practice.

\section{Limitations of the review methods}

As this review abided by the criteria and methods set out in a published protocol, we have restricted our comments to two issues. The first is whether trials have been missed or inappropriately excluded in our search and selection processes. The second concerns decisions about pooling.

Our search was comprehensive and built on searches carried out over many years (Handoll 2003a) prior to the development of our 
review. It has included the handsearch of conference proceedings and checks for ongoing trials. An inclusive and benefit-of-doubt approach during trial searches has been maintained throughout by the lead author $(\mathrm{HH})$. Additionally, trial authors of unpublished trials have been sent requests for information and trial reports. It is possible that we have missed some potentially eligible trials but, if so, these may still not be suitable for inclusion, particularly if unpublished and inadequately reported. We guarded against study selection bias by the independent selection of eligible trials by both review authors.

Where data were available, we were sparing in our decisions to pool data and especially in instances of evident heterogeneity in the study populations and interventions. While we pooled complications, it is notable that the latter were usually poorly defined and their severity is likely to differ between trials (McKay 2001).

\section{Limitations of the review evidence}

Overall, the available evidence is limited in scope and quantity, and is of uncertain validity. For several trials, the usual reservations of the reliability of evidence from small and underpowered trials apply. Especially, we were careful to avoid miss-interpreting inconclusive evidence as 'evidence of no effect'. Systematic bias, in the form of selection, performance, exclusion or assessment bias, or a combination of these could not be ruled out for any trial. Three trials were quasi-randomised and concealment of allocation was not confirmed in the other trials. Another limitation was the inadequate assessment of outcome, particularly of function. Nonvalidated outcome measures, and especially those, such as that of Gartland and Werley (Gartland 1951), based on scoring systems that combine aspects of function, pain, deformity and complications are particularly crude indicators of outcome. Considerable caution is needed when interpreting these and other outcomes when the scores have been reduced into categories such as excellent, good, fair or poor. Many trials predated the development of validated patient functional assessment instruments such as Short Form-36 (SF-36), the Disability of the Arm, Shoulder, and Hand questionnaire (DASH) and the Patient-Rated Wrist Evaluation (PRWE) (MacDermid 2000). These help to standardise functional assessment in a meaningful way and assist interpretation (Amadio 2001). Cassidy 2003 shows, however, that even if such outcomes are collected there is no guarantee that they are reported. Questions also arise on the reliability of measures of grip strength and range of motion. A particular aspect, as related above, is the inconsistency in the presentation of these outcomes in the first full report of FDA 1998.

The harvesting of bone from the iliac crest should be considered part of the intervention for autogenous grafts and hence the absence of information on this in McQueen 1996 is an important omission. Also important is the general lack of information on resource use, including the costs of bone substitute materials and applications.

\section{Applicability of the review evidence}

Generalising the findings of the included trials, should these be valid, is hampered by inadequate reporting of study details, such as the type and severity of the fracture, and bone quality. The variety of fracture classification systems, with associated issues of reliability and validity further complicates this area (Jupiter 1997). However, there is no doubt about the instability of many, if not most, of the fractures included in these trials and especially those of five trials that exclusively included redisplaced fractures. In two trials (Schmalholz 1989; Schmalholz 1990), trial entry was timed after the second reduction.

Three trials (McQueen 1996; Rajan 2006; Widman 2002) included some younger adults who are likely to have sustained hightrauma injuries in 'normal' bone. However, most of the data in these trials are from older people with low trauma injuries. It is thus questionable whether these results apply to injuries in a younger age group, where the functional demands may be greater, acceptance of cosmetic deformity less and different decisions on choice of surgery and surgical method may occur.

Surgical intervention is generally complex, with a myriad of techniques and devices available, and variation too in the overall care programmes. While, as shown in this review, trials may have aspects in common such as comparing bone scaffolding with external fixation, the ways they achieve this may be very different. Should there be sufficient evidence to inform the choice inherent in such a comparison, it is only the basic question that is addressed. There remains the issue of the best way to achieve this (i.e. what bone scaffolding; or what fixator?). This consideration applies to the choice of pinning method in Jeyam 2002; the Kapandji method used in this trial has been noted for an excess of complications (Handoll 2007). Duration of immobilisation is also a particular issue in this review. Several trials opted for a reduction in the duration of immobilisation in the bone scaffolding group relative to the control group. Early functional gains may result as in Cassidy 2003 and Schmalholz 1990 but these are not necessarily reflected in the long term (Cassidy 2003).

Neither requirements were met in Kopylov 2002, a small and prematurely terminated trial where early mobilisation was employed in both groups. Kopylov 2002 concluded that re-reduction and bone substitution of redisplaced fractures was unnecessary where people were prepared to accept cosmetic deformity and the option of later corrective surgery. Though providing an important perspective, particularly in the context of patient expectations and preferences, the evidence base for this trial is still too small.

\section{Comparisons}

A summary of the conclusions of effectiveness drawn from the findings of each comparison is provided in Table 7. Here, the effectiveness of each intervention relative to the 'control' intervention in each comparison is graded according to the categories of effectiveness described in Table 4. A concise summary of the par- 
ticipants and interventions for the 10 trials is provided in Table 5. For the first comparison, the three different types of bone scaffolding are presented separately.

Table 7. Category of effectiveness for bone grafts and bone substitutes

\begin{tabular}{|c|c|c|c|c|}
\hline Comparison & Category & Justification & Qualifiers & Comments \\
\hline $\begin{array}{l}\text { Bone scaffolding - bone } \\
\text { graft - versus conserva- } \\
\text { tive treatment (plaster } \\
\text { cast) }\end{array}$ & $\begin{array}{l}\text { 3: Trade off between } \\
\text { benefits and harms: }\end{array}$ & $\begin{array}{l}\text { Although the functional } \\
\text { outcome was under-re- } \\
\text { ported in one small trial } \\
\text { of redisplaced fractures, } \\
\text { there was evidence of } \\
\text { better anatomical out- } \\
\text { comes in the autoge- } \\
\text { nous bone graft group. } \\
\text { There was no report of } \\
\text { donor site morbidity or } \\
\text { complications but even } \\
\text { if none occurred in this } \\
\text { trial these can be serious } \\
\text { and long term. }\end{array}$ & $\begin{array}{l}\text { (1) Minimal details were } \\
\text { provided for the conser- } \\
\text { vative treatment inter- } \\
\text { vention; there remains a } \\
\text { possibility of sub-opti- } \\
\text { mal application of plas- } \\
\text { ter casts. }\end{array}$ & $\begin{array}{l}\text { A grading of } 4 \text { : unknown } \\
\text { effectiveness could also } \\
\text { apply to this compari- } \\
\text { son. }\end{array}$ \\
\hline $\begin{array}{l}\text { Bone scaffolding - No- } \\
\text { rian SRS - versus conser- } \\
\text { vative treatment (plaster } \\
\text { cast) }\end{array}$ & $\begin{array}{l}\text { 4: Unknown effective- } \\
\text { ness }\end{array}$ & $\begin{array}{l}\text { Not enough evidence } \\
\text { from two heterogeneous } \\
\text { trials, one which in- } \\
\text { cluded only acute frac- } \\
\text { tures and one which in- } \\
\text { cluded only redisplaced } \\
\text { fractures. }\end{array}$ & $\begin{array}{l}\text { (1) The acute fracture } \\
\text { trial had promising re- } \\
\text { sults but questions re- } \\
\text { main } \\
\text { over complications. The } \\
\text { extraosseous deposition } \\
\text { of Norian SRS, which } \\
\text { mainly caused } \\
\text { patient discomfort, ap- } \\
\text { parently reduced with } \\
\text { improved surgical tech- } \\
\text { nique. There was, how- } \\
\text { ever, an unusually high } \\
\text { (38/55) rate of remanip- } \\
\text { ulation in the conserva- } \\
\text { tive treatment group. } \\
\text { (2) The redisplaced frac- } \\
\text { ture trial was terminated } \\
\text { early after just } 20 \text { peo- } \\
\text { ple were recruited. The } \\
\text { trial authors concluded } \\
\text { that re-reduction and } \\
\text { bone substitution of re- } \\
\text { displaced fractures was } \\
\text { unnecessary where peo- } \\
\text { ple were prepared to ac- } \\
\text { cept cosmetic deformity }\end{array}$ & $\begin{array}{l}\text { There was earlier mobil- } \\
\text { isation in the operative } \\
\text { group of trial of acute } \\
\text { fractures. Early notice of } \\
\text { these trial results favour- } \\
\text { ing Norian SRS acted a } \\
\text { spur for Cassidy } 2003 \\
\text { (FDA trial). } \\
\text { Though } \\
\text { providing an important } \\
\text { perspective, particularly } \\
\text { in the context of patient } \\
\text { expectations and prefer- } \\
\text { ences, the evidence base } \\
\text { for the trial of redis- } \\
\text { placed fractures is still } \\
\text { too small. }\end{array}$ \\
\hline
\end{tabular}




\begin{tabular}{|c|c|c|c|c|}
\hline & & & $\begin{array}{l}\text { and the option of later } \\
\text { corrective surgery. }\end{array}$ & \\
\hline $\begin{array}{l}\text { Bone scaffolding } \\
\text { - methylmethacrylate ce- } \\
\text { ment - versus conser- } \\
\text { vative treatment (plaster } \\
\text { cast) }\end{array}$ & $\begin{array}{l}\text { 4: Unknown effective- } \\
\text { ness }\end{array}$ & $\begin{array}{l}\text { Not enough evidence } \\
\text { from one small quasi- } \\
\text { randomised trial of re- } \\
\text { displaced extra-articular } \\
\text { fractures. }\end{array}$ & $\begin{array}{l}\text { (1) The trial results for } \\
\text { the bone ce- } \\
\text { ment group were signif- } \\
\text { icantly more favourable } \\
\text { for functional, pain and } \\
\text { anatomical outcomes. } \\
\text { (2) Methylmethacrylate } \\
\text { cement is a biologically } \\
\text { inert material and gen- } \\
\text { erally viewed as unde- } \\
\text { sirable in this situation } \\
\text { although healing of the } \\
\text { cortical bone around the } \\
\text { bone cement was con- } \\
\text { firmed for all cases. }\end{array}$ & $\begin{array}{l}\text { The follow up of two } \\
\text { years for this small trial } \\
\text { were probably not long } \\
\text { enough to estab- } \\
\text { lish the long term conse- } \\
\text { quences of using methyl- } \\
\text { methacrylate cement. }\end{array}$ \\
\hline $\begin{array}{l}\text { Bone substitute ver- } \\
\text { sus "conventional treat- } \\
\text { ment" (plaster cast or ex- } \\
\text { ternal fixation). }\end{array}$ & $\begin{array}{l}\text { 4: Unknown effective- } \\
\text { ness }\end{array}$ & $\begin{array}{l}\text { Not enough evidence } \\
\text { given the complex com- } \\
\text { parison and lack of sta- } \\
\text { tistically significant dif- } \\
\text { ferences. It is likely that } \\
\text { the claims of earlier re- } \\
\text { covery of function and } \\
\text { pain with the bone sub- } \\
\text { stitute are true but the } \\
\text { data for functional mea- } \\
\text { sures at the various fol- } \\
\text { low-up times were in- } \\
\text { complete }\end{array}$ & $\begin{array}{l}\text { (1) Met FDA (USA) } \\
\text { safety requirements. } \\
\text { (2) Norian SRS was con- } \\
\text { sidered to be indicated } \\
\text { for "low impact, un- } \\
\text { stable, metaphyseal dis- } \\
\text { tal radius fractures where } \\
\text { early mobilisation is in- } \\
\text { dicated" (FDA 1998) } \\
\text { (3) Many of the ex- } \\
\text { traosseous deposits per- } \\
\text { sisted and appeared as- } \\
\text { sociated with more com- } \\
\text { plications. Questions re- } \\
\text { main about the long- } \\
\text { term complications such } \\
\text { as arthritis, potentially } \\
\text { from intra-articular de- } \\
\text { posits, and refracture } \\
\text { rate. } \\
\text { (4) There was optional } \\
\text { use of supplementary } \\
\text { wiring in both groups }\end{array}$ & $\begin{array}{l}\text { Complex control group } \\
\text { and comparison ham- } \\
\text { pered interpreta- } \\
\text { tion. Norian SRS group } \\
\text { mobilised at } 2 \text { weeks. } \\
\text { This was an industri- } \\
\text { ally sponsored trial and } \\
\text { the clear involvement } \\
\text { of the company mak- } \\
\text { ing Norian SRS, includ- } \\
\text { ing commentary by an } \\
\text { employee in the jour- } \\
\text { nal publication, should } \\
\text { be noted. }\end{array}$ \\
\hline
\end{tabular}

Bone graft, external fixa- 4: Unknown effective- Not enough evidence tion then plaster cast ver- ness sus external fixation from one small trial
(1) The invasive nature Though presented as a of bone graft harvesting trial of primary bone and of bone graft inser- grafting, the trial should tion should not be over- be viewed in terms of the looked.

(2) It is likely that the less actual interventions (including a difference in 


\begin{tabular}{|c|c|c|c|c|}
\hline & & & $\begin{array}{l}\text { serious donor-site com- } \\
\text { plications were not re- } \\
\text { ported. }\end{array}$ & $\begin{array}{l}\text { methods and mobilisa- } \\
\text { tion after } 3 \text { weeks) under } \\
\text { comparison. }\end{array}$ \\
\hline $\begin{array}{l}\text { Bone substitute versus } \\
\text { percutaneous pinning }\end{array}$ & $\begin{array}{l}\text { 4: Unknown effective- } \\
\text { ness }\end{array}$ & $\begin{array}{l}\text { Not enough evidence } \\
\text { from one small and po- } \\
\text { tentially flawed trial de- } \\
\text { spite some evidence of } \\
\text { poorer results for a par- } \\
\text { ticular bone substitute } \\
\text { (Bonesource: hydroxap- } \\
\text { atite cement), used with- } \\
\text { out additional fixation, } \\
\text { when compared with } \\
\text { Kapandji intrafocal pin- } \\
\text { ning by experienced op- } \\
\text { erators for some types } \\
\text { (Melone } 1 \text { and } 2 \text { a) of in- } \\
\text { tra-articular fractures. }\end{array}$ & $\begin{array}{l}\text { (1) Melone } 1 \text { fractures } \\
\text { are defined as "stable af- } \\
\text { ter closed reduction" and } \\
\text { thus some would con- } \\
\text { sider that cast immo- } \\
\text { bilisation would suffice } \\
\text { (Melome 1993). } \\
\text { (2) Reservations with } \\
\text { selection of the Ka- } \\
\text { pandji pinning method } \\
\text { are given in the percu- } \\
\text { taneous pinning review } \\
\text { (Handoll 2007) }\end{array}$ & $\begin{array}{l}\text { Despite the insufficient } \\
\text { evidence, it is still plau- } \\
\text { sible that Bonesource is } \\
\text { not mechanically robust } \\
\text { enough to be used with- } \\
\text { out supplementary fixa- } \\
\text { tion. }\end{array}$ \\
\hline
\end{tabular}

Bone scaffolding - bone 4: Unknown effective- Not enough evidence graft or substitute - ver- ness sus external fixation

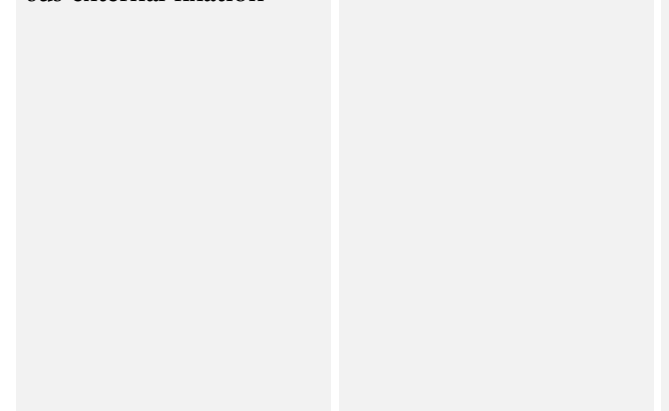

from three small heterogeneous trials; each testing a different material: bone graft, methylmethacrylate cement and Norian SRS. All were redisplaced fractures.
(1) The majority of reported complications were in the external fixation group, but there remains the potential of under-reported or longterm complications of methylmethacrylate cement and Norian SRS.

(2) The trial using bone graft did not comment on donor site complications.

(1) The potential risks of disease transmission from allograft may remain hidden even after one year follow up.
There was earlier mobilisation in the bone substitute groups of the two trials.

\begin{tabular}{|c|c|c|}
\hline $\begin{array}{l}\text { Allograft versus auto- } \\
\text { graft }\end{array}$ & $\begin{array}{l}\text { 3: Irade off between } \\
\text { benefits and harms }\end{array}$ & $\begin{array}{l}\text { quasi-randomised study } \\
\text { there was some indica- } \\
\text { tion of better functional } \\
\text { results for the autograft } \\
\text { - this needs confirma- } \\
\text { tion - but anyway these } \\
\text { need to be set in the } \\
\text { context of the serious } \\
\text { and frequent complica- } \\
\text { tions recorded for the il- } \\
\text { iac crest bone extraction. }\end{array}$ \\
\hline
\end{tabular}

Both groups had dorsal plate fixation. 


\section{A U T H OR S' C O N C L U I O N S Implications for practice}

There is some evidence that bone scaffolding may improve anatomical outcome compared with plaster cast immobilisation alone but there is insufficient evidence on functional outcome and safety. There is insufficient evidence on the effectiveness of bone scaffolding supplementary to external fixation, or relative to percutaneous pinning or to external fixation; or of different methods of bone scaffolding.

\section{Implications for research}

The evidence base for the management of distal radius fracture in adults is limited. Further research should be preceded by agreement on the priority questions for the management of these fractures, and be addressed through large multi-centre trials (Handoll 2003c). As well as adequately powered and methodologically ro- bust studies, any research on bone scaffolding materials must adequately record and report complications, including those relating to harvesting of autografts if appropriate.

\section{ACKNOWLEDGEMENTS}

We thank Lesley Gillespie for her help with the search strategy. We thank the following for helpful comments and input at the editorial and external review of the protocol and review: Lesley Gillespie, Bill Gillespie, Peter Herbison, Jesse Jupiter, Rajan Madhok, John Stothard and Janet Wale. We thank Joanne Elliott and Lindsey Elstub for their help during editorial processing.

We thank Rajan Madhok for his contribution to this review via his involvement in a former review of surgical treatment for distal radial fractures (Handoll 2003a).

We are grateful to the following for providing further information on their trials: Muthu Jeyam, Philippe Kopylov and Anders Schmalholz.

\section{REFERENCE S}

\section{References to studies included in this review}

Cassidy 2003 \{published and unpublished data\}

* Cassidy C, Jupiter JB, Cohen M, Delli-Santi M, Fennell C, Leinberry C, et al.Norian SRS cement compared with conventional fixation in distal radial fractures. Journal of Bone \& Joint Surgery American Volume 2003;85(11):2127-37.

Cohen MS, Whitman K. Calcium phosphate bone cement--the Norian skeletal repair system in orthopedic surgery. AORN Journal 1997;65(5):958-62.

Fennell CW, Husband JB, Cassidy C, Leinberry C, Cohen MS, Jupiter J. Norian SRS versus conventional therapy in distal radius fracture treatment [Abstract]. Journal of Bone and Joint Surgery British Volume 2000;82 Suppl 2:170.

Husband JB, Cassidy C, Leinberry C, Cohen MS, Jupiter JB. Multicenter clinical trial of Norian SRS vs conventional therapy in the treatment of distal radius fractures: preliminary results [Abstract]. Orthopaedic Transactions 1997;21(1):140-1. McQueen M. The use of human SRS in fractures of the distal radius. In: The National Research Register, Issue 2, 2000. Oxford: Update Software.

McQueen M. The use of Norian SRS in fractures of the distal radius. Poster displayed in Department of Orthopaedic Surgery, Edinburgh University, UK 1996.

McQueen MM. personal communication April 302002.

Jeyam 2002 \{published and unpublished data\}

Andrew JG. A study to compare the efficacy of "Bone Source" hydroxyapatite paste with that of Kapandji wiring in the treatment of displaced fractures of the distal radius in elderly patients. In:
The National Research Register, Issue 2, 2000. Oxford: Update Software.

Jeyam M. personal communication March 112003.

* Jeyam M, Andrew JG, Muir LTSW, McGovern A. Controlled trial of distal radial fractures treated with a resorbable bone mineral substitute. Journal of Hand Surgery - British Volume 2002;27(2): $146-9$.

McKee MD. Hydroxyapatite cement was not as effective as intrafocal Kirschner-wire fixation for acute fractures of the distal part of the radius (commentary). Journal of Bone \& Joint Surgery American Volume 2003;85(2):386.

Kopylov 1999 \{published and unpublished data\}

Kopylov P. personal communication July 2007.

Kopylov P, Aspenberg P, Yuan X, Ryd L. Radiostereometric analysis of distal radial fracture displacement during treatment. A randomized study comparing Norian SRS and external fixation in 23 patients. Acta Orthopaedica Scandinavica 2001;72(1):57-61.

Kopylov P, Jonsson K, Aspenberg P. Resorption of the ulnar styloid in distal radial fractures - a possible explanation to the pain at ulnar border of the wrist [Abstract]. Journal of Bone and Joint Surgery British Volume 2001;83 Suppl 2:259.

Kopylov P, Jonsson K, Runnquist K, Aspenberg P. Norian SRS, an injectable calcium phosphate, compared to external fixation in the treatment of unstable distal radius fractures [Abstract]. Orthopaedic Transactions 1997;21(1):141.

Kopylov P, Jonsson K, Runnquist K, Aspenberg P. Norian SRS; an injectable calcium phosphate, compared to external fixation in the treatment of unstable distal radial fractures [Abstract]. Journal of Hand Surgery - British Volume 1997;22 Suppl 1:21.

${ }^{*}$ Kopylov P, Runnqvist K, Jonsson K, Aspenberg P. Norian SRS 
versus external fixation in redisplaced distal radial fractures. A randomized study in 40 patients. Acta Orthopaedica Scandinavica $1999 ; 70(1): 1-5$

Kopylov 2002 \{published and unpublished data\}

Kopylov P. personal communication July 182007.

* Kopylov P, Adalberth K, Jonsson K, Aspenberg P. Norian SRS versus functional treatment in redisplaced distal radial fractures: a randomised study in 20 patients. Journal of Hand Surgery - British Volume 2002;27(6):538-41.

McQueen 1996 \{published data only\}

McQueen MM, Court-Brown CM. Unstable fractures of the distal radius: a prospective randomized comparison of four treatment methods [Abstract]. Orthopaedic Transactions 1997;21(2):595-6. * McQueen MM, Hajducka C, Court-Brown CM. Redisplaced unstable fractures of the distal radius. A prospective randomised comparison of four methods of treatment. Journal of Bone and Joint Surgery - British Volume 1996;78(3):404-9.

Rajan 2006 \{published and unpublished data\}

Fornaro J, Zellweger R, Sommer C, Trentz O. Repair of comminuted distal radius fractures: Allogenic versus autogeneic transplants. Orthopaedic Trauma Association; Combined meeting with the American Association for the Surgery of Trauma. 2000 Oct 12; San Antonio, Texas. Monroe, NY: HWB Foundation, 2000:http://www.hwbf.org/ota/am/ota00/otapa/OTA00319.htm (accessed 15/12/2000).

* Rajan GP, Fornaro J, Trentz O, Zellweger R. Cancellous allograft versus autologous bone grafting for repair of comminuted distal radius fractures: a prospective, randomized trial. Journal of TraumaInjury Infection \& Critical Care 2006;60(6):1322-9.

Sanchez-Sotelo 2000 \{published data only\}

McKee MD. The Norian skeletal repair system was effective for fractures of the distal radius (Commentary). Journal of Bone \& Joint Surgery - American Volume 2001;83(2):302.

Sanchez-Sotelo J, Munuera L. Norian SRS for the treatment of distal radius fractures: a prospective randomized study [Abstract]. Journal of Bone and Joint Surgery - British Volume 1999;81 Suppl 2: 166

* Sanchez-Sotelo J, Munuera L, Madero R. Treatment of fractures of the distal radius with a remodellable bone cement. A prospective, randomised study using Norian SRS. Journal of Bone and Joint Surgery - British Volume 2000;82(6):856-63.

Schmalholz 1989 \{published data only\}

Schmalholz A. personal communication August 272007.

* Schmalholz A. Bone cement for redislocated Colles' fracture. A prospective comparison with closed treatment. Acta Orthopaedica Scandinavica 1989;60(2):212-7.

Schmalholz 1990 \{published data only\}

Schmalholz A. personal communication August 272007.

* Schmalholz A. External skeletal fixation versus cement fixation in the treatment of redislocated Colles' fracture. Clinical Orthopaedics \& Related Research 1990;(254):236-41.

Widman 2002 \{published data only\}

Widman J, Isacson J. Primary bone grafting does not improve the results in severely displaced distal radius fractures. International Orthopaedics 2002;26(1):20-2.

\section{References to studies excluded from this review}

Chapman 1997 \{published data only\}

* Chapman MW, Bucholz R, Cornell C. Treatment of acute fractures with a collagen-calcium phosphate graft material - A randomized clinical trial. Journal of Bone \& Joint Surgery - American Volume 1997;79(4):495-502.

Moran CG. Treatment of acute fractures with a collagen-calcium phosphate graft material - A randomized clinical trial [letter]. Journal of Bone and Joint Surgery - American Volume 1998;80(3): 454.

Dickson 2002 \{published data only\}

Dickson KF, Friedman J, Buchholz JG, Flandry FD. The use of BoneSource hydroxyapatite cement for traumatic metaphyseal bone void filling. Journal of Trauma-Injury Infection \& Critical Care 2002;53(6):1103-8.

\section{McQueen 2001 \{unpublished data only\}}

* McQueen M. A comparison of external fixation alone versus external fixation with bone source for the treatment of unstable distal radial fractures. In: The National Research Register, Issue 4, 2000. Oxford: Update Software.

McQueen MM. personal communication April 302002.

\section{Schmalholz 1988 \{published data only\}}

Schmalholz A, Alberts KA. A scintimetric study of Colles' fracture. Comparison between cementation and closed treatment. Acta Radiologica 1988;29(6):715-7.

\section{Wyrick 1999 \{unpublished data only\}}

Wyrick J, Spieles C, Ansari I. A prospective, randomised comparison of corraline hydroxyapatite and autogenous bone graft in the treatment of distal radius fractures (commentary on paper presented at the American Society for Surgery of the Hand 54th Annual Meeting, Sept 2-4 1999, Boston, USA). commentary in http://www.eradius.com/research.htm (accessed 10/03/2002).

Zimmermann 2003 \{published data only\}

Zimmermann R, Gabl M, Lutz M, Angermann P, Gschwentner M, Pechlaner S. Injectable calcium phosphate bone cement Norian SRS for the treatment of intra-articular compression fractures of the distal radius in osteoporotic women. Archives of Orthopaedic \& Trauma Surgery 2003;123(1):22-7.

\section{References to ongoing studies}

\section{Barbier 2008 \{unpublished data only\}}

Barbier O. Allomatrix injectable putty in distal radius fractures. Protocol for a randomised, controlled clinical study in unstable fractures of the distal radius. Controlled Clinical Trials: http:// clinicaltrials.gov/show/NCT00274378 (assessed 13/09/06).

\section{Additional references}

Altman 2003

Altman DG, Bland JM. Interaction revisited: the difference between two estimates. BMJ 2003;326(7382):219.

Amadio 2001

Amadio PC. Outcome assessment in hand surgery and hand therapy: an update. Journal of Hand Therapy 2001;14(2):63-7. 


\section{Arrington 1996}

Arrington ED, Smith WJ, Chambers HG, Bucknell AL, Davino NA. Complications of iliac crest bone graft harvesting. Clinical Orthopaedics and Related Research 1996;(329):300-9.

\section{Atkins 2003}

Atkins RM. Aspects of current management: Complex regional pain syndrome. Journal of Bone and Joint Surgery - British Volume 2003;85(8):1100-6.

Belsole 1993

Belsole RJ, Hess AV. Concomitant skeletal and soft tissue injuries. Orthopedic Clinics of North America 1993;24(2):327-31.

\section{BMJ 2006}

A guide to the text. Clinical Evidence Online http:// www.clinicalevidence.com/ceweb/about/guide.jsp (accessed 24 March 2006).

\section{Carson 2007}

Carson JS, Bostrom MP. Synthetic bone scaffolds and fracture repair. Injury 2007;38(Suppl 1):S33-S37.

\section{Chitnavis 1999}

Chitnavis J. The wrist. In: Pynsent PB, Fairbank JC, Carr AJ editor (s). Classification of musculoskeletal trauma. Oxford: Butterworth Heinemann, 1999:146-70.

\section{Cooney 1993}

Cooney WP. Fractures of the distal radius. A modern treatmentbased classification. Orthopedic Clinics of North America 1993;24 (2):211-6.

\section{Cummings 1985}

Cummings SR, Kelsey JL, Nevitt MC, O’Dowd KJ. Epidemiology of osteoporosis and osteoporotic fractures. Epidemiologic Reviews 1985;7:178-208

\section{FDA 1998}

U.S. Food and Drug Administration - Center for Devices and Radiological Health. Norian(R) SRS(R) Cement. P970010. Issued 23-12-1998. FDA Web site: http://www.fda.gov/cdrh/pdf/ p970010.html (accessed 31/08/2000).

\section{Fernandez 1996}

Fernandez DL, Jupiter JB. Fractures of the distal radius. A practical approach to management. 1st Edition. New York: Springer-Verlag, 1996.

\section{Frykman 1967}

Frykman G. Fracture of the distal radius including sequelae-shoulder-hand-finger syndrome, disturbance in the distal radioulnar joint and impairment of nerve function. A clinical and experimental study. Acta Orthopaedica Scandinavica Supplementum 1967;108:3-153

\section{Gartland 1951}

Gartland JJ, Werley CW. Evaluation of healed Colles' fractures. Journal of Bone and Joint Surgery - American Volume 1951;33(4): 895-910.

\section{Handoll 2003a}

Handoll HH, Madhok R. Surgical interventions for treating distal radial fractures in adults (Cochrane review). Cochrane Database of Systematic Reviews 2003, Issue 3. [DOI: 10.1002/ 14651858.CD003209]

\section{Handoll 2003b}

Handoll HH, Madhok R. Conservative interventions for treating distal radial fractures in adults (Cochrane Review). Cochrane Database of Systematic Reviews 2003, Issue 2. [DOI: 10.1002/ 14651858.CD000314]

\section{Handoll 2003c}

Handoll HHG, Madhok R. From evidence to best practice in the management of fractures of the distal radius in adults: working towards a research agenda. BMC Musculoskeletal Disorders 2003;4 (27): $1-15$.

\section{Handoll 2007}

Percutaneous pinning for treating distal radial fractures in adults. Handoll HHG, Vaghela MV, Madhok R. Cochrane Database of Systematic Reviews 2007, Issue 3. [DOI: 10.1002/ 14651858.CD006080.pub2]

\section{Higgins 2003}

Higgins JP, Thompson SG, Deeks JJ, Altman DG. Measuring inconsistency in meta-analyses. BMJ 2003;327(7414):557-60.

\section{Higgins 2005}

Higgins JPT, Green S, editors. Highly sensitive search strategies for identifying reports of randomized controlled trials in MEDLINE. Cochrane Handbook for Systematic Reviews of Interventions 4.2.5 [updated May 2005]; Appendix 5b. www.cochrane.org/resources/ handbook/hbook.htm (accessed 31 July 2007).

\section{Jupiter 1997}

Jupiter JB, Fernandez DL. Comparative classification for fractures of the distal end of the radius. Journal of Hand Surgery - American Volume 1997;22(4):563-71.

\section{Knirk 1986}

Knirk JL, Jupiter JB. Intra-articular fractures of the distal end of the radius in young adults. Journal of Bone and Joint Surgery - American Volume 1986;68(5):647-59.

\section{Kreder 1996}

Kreder HJ, Hanel DP, McKee M, Jupiter J, McGillivary G, Swiontkowski MF. X-ray film measurements for healed distal radius fractures [published erratum appears in J Hand Surg [Am] 1996 May;21(3):532]. Journal of Hand Surgery - American Volume 1996; 21(1):31-9.

\section{MacDermid 2000}

MacDermid JC, Richards RS, Donner A, Bellamy N, Roth JH. Responsiveness of the short form-36, disability of the arm, shoulder, and hand questionnaire, patient-rated wrist evaluation, and physical impairment measurements in evaluating recovery after a distal radius fracture. Journal of Hand Surgery - American Volume 2000;25(2):330-40.

\section{McKay 2001}

McKay SD, MacDermid JC, Roth JH, Richards RS. Assessment of complications of distal radius fractures and development of a complication checklist. Journal of Hand Surgery - American Volume 2001;26(5):916-22.

McKee 2003

McKee MD. Hydroxyapatite cement was not as effective as intrafocal Kirschner-wire fixation for acute fractures of the distal part of the radius (commentary). Journal of Bone \& Joint Surgery American Volume 2003;85(2):386. 


\section{Melone 1993}

Melone CPJr. Distal radius fractures: patterns of articular fragmentation. Orthopedic Clinics of North America 1993;24(2): $239-53$.

Mjoberg 1984

Mjoberg B, Pettersson H, Rosenqvist R, Rydholm A. Bone cement, thermal injury and the radiolucent zone. Acta Orthopaedica Scandinavica 1984;55(6):597-600.

\section{Muller 1991}

Muller M, Allgower M, Schneider R, Willenegger H. Manual of internal fixation: techniques recommended by the AO-ASIF Group. 3rd Edition. Berlin: Springer-Verlag, 1991.

\section{O’Neill 2001}

O'Neill TW, Cooper C, Finn JD, Lunt M, Purdie D, Reid DM, et al.Incidence of distal forearm fracture in British men and women. Osteoporosis International 2001;12(7):555-8.

\section{Older 1965}

Older TM, Stabler EV, Cassebaum WH. Colles fracture: Evaluation and selection of therapy. Journal of Trauma-Injury Infection \& Critical Care 1965;5(4):469-76.

\section{Sahlin 1990}

Sahlin Y. Occurrence of fractures in a defined population: a 1-year study. Injury 1990;21(3):158-60.

\section{Singer 1998}

Singer BR, McLauchlan GJ, Robinson CM, Christie J.

Epidemiology of fractures in 15,000 adults: the influence of age and gender. Journal of Bone and Joint Surgery - British Volume 1998; 80(2):243-8

\section{Taleisnik 1984}

Taleisnik J, Watson HK. Midcarpal instability caused by malunited fractures of the distal radius. Journal of Hand Surgery - American Volume 1984;9(3):350-7.

\section{Van Staa 2001}

Van Staa TP, Dennison EM, Leufkens HG, Cooper C.

Epidemiology of fractures in England and Wales. Bone 2001;29(6): $517-22$.

* Indicates the major publication for the study 
CHARACTERISTICS OF STUDIES

\author{
Characteristics of included studies [ordered by study ID]
}

Cassidy 2003

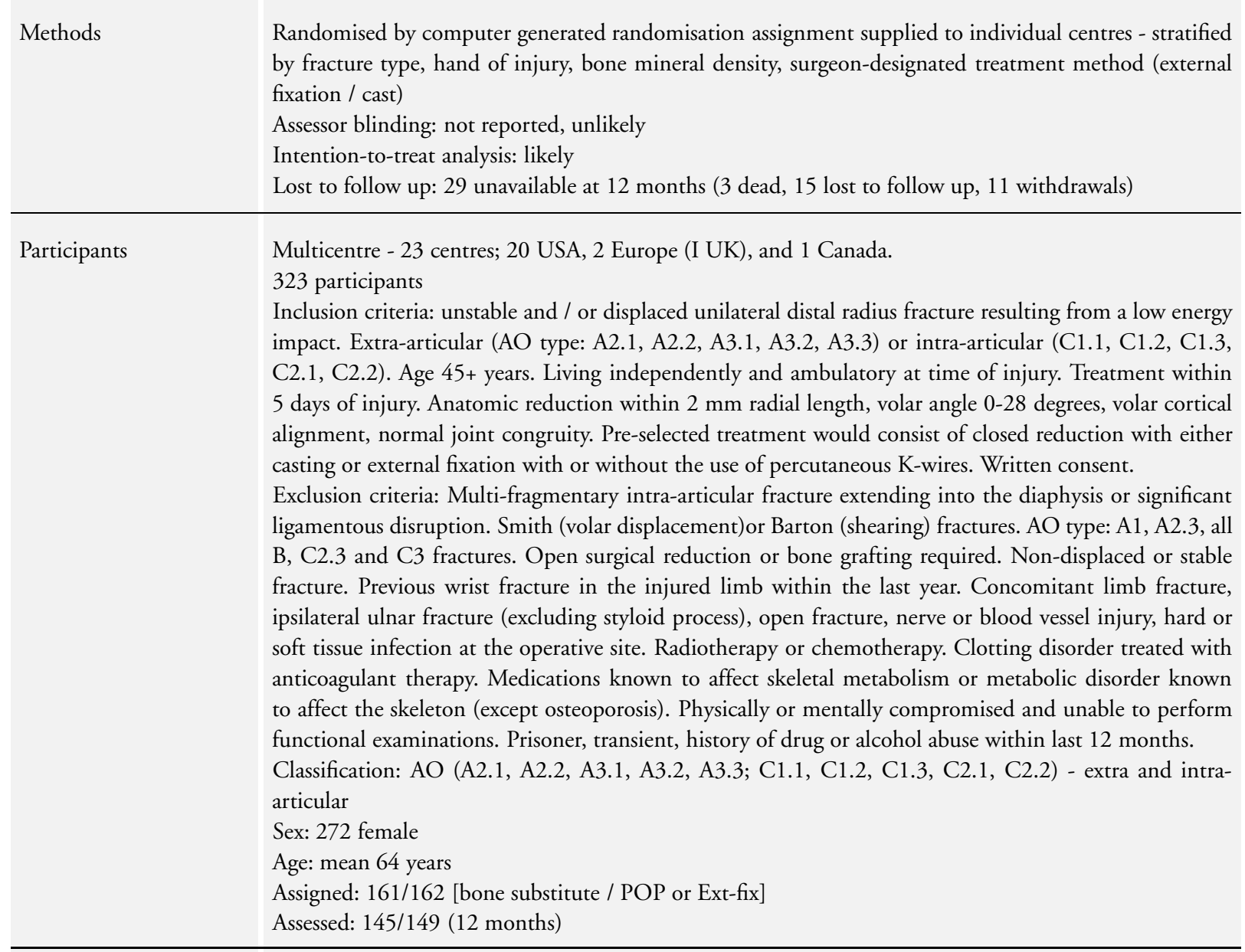

Interventions

Timing of intervention: before 5 days from injury. Surgeons were asked to indicate their preference (cast or external fixation) for treating each participant before treatment allocation.

(1) Closed reduction. Norian SRS (calcium-phosphate bone cement) injected into cavity either through a dorsal percutaneous or a limited open technique (haematoma and debris cleared, bone compacted). Short arm (below-elbow)plaster cast for 2 weeks. Occupational therapy, including wrist and forearm exercises started at 2 weeks. Removable splint for 4 weeks. Mean time of immobilisation $=16$ days.

(2) Closed reduction and short arm cast or external fixator for 6 to 8 weeks. Occupational therapy, including wrist and forearm exercises started after removal of cast at 6-8 weeks.

Mean time of immobilisation $=40$ days (cast); 45 days (fixator).

Use of percutaneous K-wires (not Kapandji pinning) was optional in both groups.

Before discharge, patients were instructed in finger exercises and limb elevation. 
Cassidy 2003 (Continued)

\begin{tabular}{ll} 
Outcomes & $\begin{array}{l}\text { Length of follow up: } 12 \text { months; also assessed at 1,2, } 4 \text { and } 6-8 \text { weeks and } 3 \text { and } 6 \text { months. } \\
\text { (1) Functional: at } 3 \text { and } 12 \text { months. Jebsen dexterity test, SF-36 Health Status Questionnaire, Green and } \\
\text { O'Brien scoring scheme, self-reported hand use, grip strength, pain, range of motion (flexion, extension, } \\
\text { radial and ulnar deviation, pronation, supination), finger range of motion. } \\
\text { (2) Clinical: swelling. Complications: overall number, loss of reduction, secondary treatment, non-union } \\
\text { (none), infection, cellulitis, osteomyelitis, neuropathies, CTS, RSD, tendinopathies, tendon rupture, } \\
\text { shoulder events (pain, bursitis), pin problems, iatrogenic fractures, further wrist injury, extraosseous Norian } \\
\text { SRS deposits and extrusions } \\
\text { Other (shoulder pain / bursitis, further wrist injury, pin problems etc): } 9 / 13 \\
\text { (3) Anatomical: X-ray at all follow-up times. Radial shortening, dorsal angulation, radial angulation, ulnar } \\
\text { variance, radial shift, articular alignment / step-off. Fracture healing. Successful radiographic outcome. }\end{array}$ \\
\hline Notes & $\begin{array}{l}\text { This trial appeared Handoll 2003a under FDA 1998. } \\
\text { Interim analyses, published in conference abstracts, conducted by several centres. Detailed description of } \\
\text { the technical aspects of Norian SRS application are given in Cohen } 1997 . \\
\text { Protocol violations were } 19 \text { participants whose injury occurred between } 6 \text { and } 9 \text { days after injury; } 8 \\
\text { participants whose age was < 45 years (28.9 to } 44.9 \text { years); } 4 \text { not meeting the reduction criteria; } 6 \text { with } \\
\text { wrong fracture types; } 1 \text { only giving verbal consent; and } 1 \text { on osteoporosis medication. }\end{array}$ \\
\hline $\begin{array}{l}\text { Full report published in Cassidy } 2003 . \text { This report indicated that three authors of the report were employees } \\
\text { of Norian (the manufacturer of the bone cement) who sponsored the trial. Other authors also received } \\
\text { expenses and grants from Norian. }\end{array}$ \\
\hline Allocation concealment?
\end{tabular}

Jeyam 2002

Methods $\quad$ Randomised by numbered, opaque, sealed envelopes (see Notes)

Assessor blinding: not reported

Intention-to-treat analysis: slight problems, baseline data not given for 3 participants (see below)

Loss to follow up: 3 ( 2 deaths, 1 excluded due to protocol violation (non-standard Kapandji wiring))

Darticipants
21 participants
Inclusion criteria: acute $(<7$ days old) displaced distal radius fracture, age $>60$ years, Melone type 1 or
2a fractures, informed consent.
Exclusion criteria: not stated
Classification: Melone (intra-articular)
Sex: all female (21)
Age: mean 73 years
Assigned: ?/? [Bone cement / Kapandji]
Assessed: $9 / 9$ (at 6 months)




Timing of intervention: not stated, but acute fractures. Randomisation after closed manipulation under
anaesthesia.
(1) Hydroxyapatite bone cement: Orthofix BoneSource. Small dorsal insertion of fracture site; haematoma
and debris cleared; cement added to fill void, wound closed after, on average, 15 minutes when the cement
had set.
(2) Kapandjis intrafocal pinning ( 2 or 3 K-wires inserted at fracture site). Tourniquet used. K-wires
removed at 6 weeks.
Short arm cast applied for 4 weeks in both groups. All patients referred to physiotherapy.

Outcomes Length of follow up: 6 months; also assessed at 1 day, 1, 3, 6 and 12 weeks.

(1) Functional: mass grip strength, range of movement (results provided for flexion).

(2) Clinical: Death (2 died). Complications: revision procedure (none).

(3) Anatomical: X-ray at all follow-up times. Dorsal angle, radial angle, ulnar variance.

Notes

Details of randomisation method received from M Jeyam on 12/03/2003. However, an evidence-based orthopaedics commentary on this article (JBJS-Am 2003:85(2);386) stated that the allocation was not "fully concealed")

\section{Risk of bias}

\begin{tabular}{l|ll}
\hline Item & Authors' judgement & Description \\
\hline Allocation concealment? & Unclear & B - Unclear \\
\hline
\end{tabular}

\section{Kopylov 1999}

Methods Randomised by envelopes (stratification by gender and fracture type (extra- or intra-articular)) drawn by nurse before surgery

Assessor blinding: not reported (some independent assessors and independent checks of data collection) Intention-to-treat analysis: likely

Loss to follow up: 2 (at 1 year)

\begin{tabular}{ll}
\hline Participants & Teaching Hospital, Sweden \\
& 40 participants \\
Inclusion criteria: redisplaced unstable distal radial fracture (redisplaced to 20 degrees dorsal angulation \\
or $2+\mathrm{mm}$ axial compression or $2+\mathrm{mm}$ incongruity in radiocarpal or distal radio-ulnar joints) within 7- \\
10 days after initial reduction; women age $50-80$ years; men $60-80$ years. Written consent. \\
Exclusion criteria: not stated. \\
Classification: not stated (extra-articular and intra-articular) \\
Sex: 36 female \\
Age: mean 67 years \\
Assigned: $20 / 20$ [bone substitute / Ext-fix ] \\
Assessed: $19 / 19$ (1 year) \\
Timing of intervention: after $7-10$ days from initial reduction and injury. All had closed reduction using \\
fingertraps. \\
(1) Fracture exposed through $<5 \mathrm{~cm}$ dorsal incision. After clean-up (haematoma, callus and debris were \\
scrapped out), Norian skeletal repair system (SRS) - bone cement - injected to fill defect. Short arm dorsal
\end{tabular}


splint for 2 weeks, then wrist mobilisation

(2) Limited open incision then Hoffman external fixator for 5 weeks. Two pins inserted into 2nd metacarpal and 2 into radial shaft. Fixator removed and wrist mobilised after 5 weeks.

All had physiotherapy as indicated.

Outcomes Length of follow up: 1 year; also assessed at 1 day, 2, 5 and 7 weeks, and 3 and 6 months post-op.

(1) Functional: residual disability (VAS), grip strength, pain (VAS), range of movement (extension and supination).

(2) Clinical: patient satisfaction (VAS - no data). Complications: CTS, pin track infection, skin adhesion, wrist swelling, tendon rupture (EPL), persistent finger stiffness, extrusion of Norian SRS (no data).

(3) Anatomical: X-ray at all follow-up times. Radial angle, dorsal angle, ulnar variance, lateral angle between scaphoid and lunate.

Notes
All patients operated on by one surgeon.
No results were available from two reports for this trial. One reported radiostereometric analysis results of
a sub-group of 23 trial participants. The other, a conference abstract, reported on an "incidental finding"
of resorption of the lateral aspect of the ulnar styloid process in 27 participants.
Extra details, including method of randomisation received from Philippe Kopylov

Risk of bias

\begin{tabular}{lll}
\hline Item & Authors' judgement & Description \\
\hline Allocation concealment? & Unclear & B - Unclear \\
\hline
\end{tabular}

\section{Kopylov 2002}

\begin{tabular}{|c|c|}
\hline Methods & $\begin{array}{l}\text { Randomised by envelopes (stratification by gender and fracture type (extra- or intra-articular)) drawn by } \\
\text { nurse before surgery } \\
\text { Assessor blinding: not reported (some potentially independent assessors and data checked by external } \\
\text { person) } \\
\text { Intention-to-treat analysis: likely } \\
\text { Loss to follow up: } 2 \text { (at } 6 \text { months) }\end{array}$ \\
\hline Participants & $\begin{array}{l}\text { Teaching Hospital, Sweden } \\
20 \text { participants } \\
\text { Inclusion criteria: redisplaced distal radial fracture (redisplaced to } 20 \text { degrees dorsal angulation or } 2+\mathrm{mm} \\
\text { axial shortening or } 2+\text { mm incongruity in radiocarpal or distal radio-ulnar joints) within } 7-10 \text { days after } \\
\text { initial reduction; women age } 50-80 \text { years; men } 60-80 \text { years. Written consent. } \\
\text { Exclusion criteria: people with distal forearm fracture, open fracture or other severe injuries requiring } \\
\text { hospitalisation. } \\
\text { Classification: not stated (extra-articular and intra-articular) } \\
\text { Sex: all female (20) } \\
\text { Age: mean } 66 \text { years } \\
\text { Assigned: } 9 / 11 \text { [bone substitute / control] } \\
\text { Assessed: } 8 / 10 \text { (6 months) }\end{array}$ \\
\hline
\end{tabular}


Kopylov 2002 (Continued)

Timing of intervention: after 7-10 days from initial reduction and injury
(1) Closed reduction (using fingertraps)then fracture exposed through $<5 \mathrm{~cm}$ dorsal incision. After clean-
up (haematoma, callus and debris were scrapped out), and further reduction, as needed, Norian skeletal
repair system (SRS) - bone cement - injected to fill defect. General or regional anaesthesia. Short arm
dorsal splint for 1 week.
(2) Original cast retained for 1 further week; no re-reduction.
All had their cast removed after 1 week and given mobilisation and instructions by physiotherapist. All
given plastic removable splint for intermittent wear for up to 3 weeks.

Outcomes Length of follow up: 6 months; also assessed at 1, 4 and 7 weeks, and 3 months post study inclusion.

(1) Functional: residual disability (VAS), grip strength, pain (VAS), range of movement (pronation and supination).

(2) Clinical: patient satisfaction (no data). Complications: CTS, post-op pain due to soft-tissue extrusion of cement, transient difficulty in thumb extension, tendon rupture (EPL) (none), irritation of distal branch of radial nerve, painful and deformed wrist (corrective osteotomy performed)

(3) Anatomical: X-ray at all follow-up times. Radial angle, dorsal angle, ulnar variance, malunion (no data).

\begin{tabular}{ll}
\hline Notes & All patients operated on by one doctor. \\
Trial stopped early. \\
Twenty patients declined entry, preferring to accept wrist deformity and undergo a corrective osteotomy \\
if require at a later date. None did. \\
Extra details, including method of randomisation received from Philippe Kopylov. \\
\hline
\end{tabular}

Risk of bias

\begin{tabular}{l|ll}
\hline Item & Authors' judgement & Description \\
\hline Allocation concealment? & Unclear & B - Unclear \\
\hline
\end{tabular}

\section{McQueen 1996}

\begin{tabular}{ll}
\hline Methods & $\begin{array}{l}\text { Randomised by closed envelopes } \\
\text { Assessor blinding: not reported } \\
\text { Intention-to-treat analysis: likely } \\
\text { Loss to follow up: } 11 \text { (at } 1 \text { year) }\end{array}$ \\
\hline Participants & $\begin{array}{l}\text { Teaching Hospital, UK } \\
120 \text { participants } \\
\text { Inclusion criteria: redisplaced unstable distal radial fracture (redisplaced to }>10 \text { degrees dorsal angulation } \\
\text { or radial shortening > } 3 \text { mm). } \\
\text { Exclusion criteria: inadequate primary reduction, }>2 \text { weeks from injury to recognised instability, displaced } \\
\text { articular fragments requiring open reduction, previous malunion, mental incapacity. } \\
\text { Classification: AO (A and C) (extra-articular and intra-articular) } \\
\text { Sex: } 107 \text { female } \\
\text { Age: mean } 63 \text { years, range } 16 \text { - } 86 \text { years } \\
\text { Assigned: } 30 / 30 / 30 / 30 \text { [Graft / Ext-fix / Ext-fix with early mobilisation / POP] } \\
\text { Assessed: } 27 / 28 / 26 / 28 \text { (at } 1 \text { year) }\end{array}$ \\
\hline
\end{tabular}




\begin{tabular}{|c|c|c|}
\hline Interventions & \multicolumn{2}{|c|}{$\begin{array}{l}\text { Timing of intervention: under } 2 \text { weeks from injury } \\
\text { (1) Open reduction with dorsal approach and wedge of corticocancellous bone (from iliac crest) held by } \\
1 \text { Kirschner wire, then forearm cast for } 6 \text { weeks } \\
\text { (2) Closed reduction and Pennig external fixator for } 6 \text { weeks. Two pins inserted into } 2 \text { nd metacarpal and } \\
2 \text { into radial shaft using an open technique. Ball joint locked } \\
\text { (3) As (2) but release of ball joint of fixator at } 3 \text { weeks to allow wrist movement. } \\
\text { (4) Closed reduction, then forearm cast for } 6 \text { weeks. } \\
\text { Physiotherapy prescribed on "purely clinical grounds". Patients did not receive physiotherapy when the } \\
\text { fixator was in place. }\end{array}$} \\
\hline Outcomes & \multicolumn{2}{|c|}{$\begin{array}{l}\text { Length of follow up: } 1 \text { year; also assessed at } 6 \text { weeks, } 3 \text { and } 6 \text { months. } \\
\text { (1) Functional: activities of daily living (non-cited scale: no data), grip strength, other grips, pain (VAS } \\
\text { no data), range of movement (overall, flexion and extension). } \\
\text { (2) Clinical: Complications: recurrent instability, malunion, pin track or K-wire infections, wound infec } \\
\text { tion, RSD, CTS, } \\
\text { dorsal medial neuropraxia, tendon rupture (EPL), carpal collapse } \\
\text { (3) Anatomical: X-ray at all follow-up times. Dorsal angulation, radial shortening, carpal malalignment } \\
\text { malunion. }\end{array}$} \\
\hline Notes & \multicolumn{2}{|c|}{ Data from the two external fixation groups are combined for the purposes of this review. } \\
\hline \multicolumn{3}{|l|}{ Risk of bias } \\
\hline Item & Authors' judgement & Description \\
\hline Allocation concealment? & Unclear & B - Unclear \\
\hline
\end{tabular}

Rajan 2006

Methods

Randomised by date of admission

Assessor blinding: potentially for independent external radiologist but no mention of adequate safeguards for independent surgeon assessing clinical outcome

Intention-to-treat analysis: slight problems as baseline data or results were not given for 3 patients who did not accept iliac crest surgery for bone harvesting

Loss to follow up: probably 0 (at 12 months)

Teaching hospital, Switzerland
93 participants (including 3 exclusions)
Inclusion criteria: fracture instability (requiring primary or secondary - after failed plaster cast treatment
- open reduction and internal fixation) and existence of a dorsal metaphyseal void after closed reduction
indicating bone grafting. Instability defined if 2 or more of the following criteria met: dorsal angulation >
20 degrees, loss of radial length > $10 \mathrm{~mm}$, intra-articular extension of fracture, severe dorsal metaphyseal
comminution, radioulnar separation.
Exclusion criteria: severe impairment of the surrounding soft-tissue; under immunosuppression; suffering
from malignant, rheumatoid or infectious diseases; multiple upper extremity injuries.
Classification: AO (A3, C2, C3) (extra- and intra-articular)
Sex: 73 female (of 90$)$
Age: mean 61 years, range $19-90$ years


Rajan 2006 (Continued)

\begin{tabular}{|c|c|c|}
\hline & \multicolumn{2}{|c|}{$\begin{array}{l}\text { Assigned: 44/49 [Allograft / Autograft] } \\
\text { Assessed: 44/46 (1 year) }\end{array}$} \\
\hline Interventions & \multicolumn{2}{|c|}{$\begin{array}{l}\text { Timing of intervention: primary or secondary fixation at mean } 5.5 \text { days from injury. All had open reduction } \\
\text { using traction, dorsal incision/approach and dorsal plate (quarter-tube plates) fixation. } \\
\text { (1) Allogenic bone-graft substitute (Tutoplast cancellous chips). General anaesthesia except } 6 \text { plexus } \\
\text { anaesthesia. } \\
\text { (2) Autogenic bone-graft (from iliac crest - method stated). All general anaesthesia. } \\
\text { Dorsal splint, replaced after swelling resolved by circular forearm cast for } 4 \text { weeks. Physiotherapy after cast } \\
\text { removal. }\end{array}$} \\
\hline Outcomes & \multicolumn{2}{|c|}{$\begin{array}{l}\text { Length of follow up: } 1 \text { year; also assessed at } 1 \text { and } 2 \text { weeks, and } 3 \text { months. } \\
\text { (1) Functional: restrictions on daily living, time to return to work, grip strength, pain (VAS - but results } \\
\text { categorical), range of motion (extension, radial and ulnar deviation, pronation, supination). } \\
\text { (2) Clinical: patient satisfaction. Complications: reoperation (plate removal). Donor site complications } \\
\text { (pain, parathesias, haematoma, infection, seroma). Non-compliance (refusal for bone harvesting). } \\
\text { (3) Anatomical: X-ray at all follow-up times. Dorsal (volar) angulation, radial inclination, ulnar variance, } \\
\text { radial length, articular incongruence (step off), radioulnar separation (none). } \\
\text { (4) Resource: length of hospital stay }\end{array}$} \\
\hline \multicolumn{3}{|l|}{ Notes } \\
\hline \multicolumn{3}{|l|}{ Risk of bias } \\
\hline Item & Authors' judgement & Description \\
\hline Allocation concealment? & No & $\mathrm{C}$ - Inadequate \\
\hline
\end{tabular}

\section{Sanchez-Sotelo 2000}

\begin{tabular}{|c|c|}
\hline Methods & $\begin{array}{l}\text { Method of randomisation not stated } \\
\text { Assessor blinding: not reported } \\
\text { Intention-to-treat analysis: likely } \\
\text { Lost to follow up: probably } 0\end{array}$ \\
\hline Participants & $\begin{array}{l}\text { Teaching hospital, Spain } \\
110 \text { participants } \\
\text { Inclusion criteria: age } 50 \text { to } 85 \text { years, AO: A3 (extra-articular)or C2 (intra-articular)distal radius fractures. } \\
\text { Presentation within } 24 \text { hours of fracture. Informed consent. } \\
\text { Exclusion criteria: injuries in the ipsilateral upper limb or contralateral wrist; previous injuries to fractured } \\
\text { wrist. } \\
\text { Classification: AO (A3, C2) (extra- and intra-articular) } \\
\text { Sex: } 97 \text { female } \\
\text { Age: mean } 66 \text { years } \\
\text { Assigned: } 55 / 55 \text { [bone substitute / POP] } \\
\text { Assessed: } 55 / 55 \text { (1 year) }\end{array}$ \\
\hline
\end{tabular}


Sanchez-Sotelo 2000 (Continued)

\begin{tabular}{|c|c|c|}
\hline Interventions & \multicolumn{2}{|c|}{$\begin{array}{l}\text { Timing of intervention: soon after fracture } \\
\text { (1) Closed reduction using fingertrap system monitored by fluoroscopy. Debris (loose fragments etc) } \\
\text { removed through } 1 \mathrm{~cm} \text { incision and Norian SRS (calcium-phosphate bone cement) injected into cavity. } \\
\text { Below-elbow cast applied in slight palmar flexion and ulnar deviation for } 2 \text { weeks. } \\
\text { (2) Closed manipulation under traction and below-elbow cast applied in slight palmar flexion and ulnar } \\
\text { deviation for } 6 \text { weeks. } \\
\text { Active assisted movements of digits, elbow and shoulder encouraged in both groups. Heavy loads avoided } \\
\text { until } 12 \text { weeks. }\end{array}$} \\
\hline Outcomes & \multicolumn{2}{|c|}{$\begin{array}{l}\text { Length of follow up: } 12 \text { months; also assessed at 1, 2, } 3 \text { and } 6 \text { weeks, } 3 \text { and } 6 \text { months. } \\
\text { (1) Functional: Overall grades clinical scale (Bradway } 1989 \text { modification of Green and O'Brien), grip } \\
\text { strength, radio-ulnar and radiocarpal pain (VAS), range of movement (flexion, extension, radial and ulnar } \\
\text { deviation, pronation, supination). } \\
\text { (2) Clinical: Complications: re-manipulation and new cast, malunion, median nerve compression, RSD, } \\
\text { tendon rupture (EPL), refracture, infection (none), extraosseous Norian SRS deposits / extrusions, extra } \\
\text { surgery to remove deposit. } \\
\text { (3) Anatomical: X-ray at above follow-up times. Volar angle, radial shortening, radial width, ulnar variance, } \\
\text { radial angle, intra-articular gap. Malunion. }\end{array}$} \\
\hline Notes & \multicolumn{2}{|c|}{$\begin{array}{l}\text { All treated by one surgeon. } \\
\text { Earlier abstract (Sanchez-Sotelo 1999) reported results of } 69 \text { participants at } 6 \text { months. }\end{array}$} \\
\hline \multicolumn{3}{|l|}{ Risk of bias } \\
\hline Item & Authors' judgement & Description \\
\hline Allocation concealment? & Unclear & B - Unclear \\
\hline
\end{tabular}

\section{Schmalholz 1989}

\begin{tabular}{|c|c|}
\hline Methods & $\begin{array}{l}\text { Randomised by date of birth } \\
\text { Assessor blinding: not reported } \\
\text { Intention-to-treat analysis: likely, but interim data not presented for } 2 \text { patients who died } \\
\text { Loss to follow up: } 2 \text { (at } 2 \text { years) }\end{array}$ \\
\hline Participants & $\begin{array}{l}\text { Teaching hospital, Sweden } \\
49 \text { participants } \\
\text { Inclusion criteria: closed redisplaced unstable distal radial fracture, dorsal angulation } 30+\text { degrees and / or } \\
\text { axial compression } 5+\text { mm following second closed manipulation (done } 8 \text { to } 14 \text { days after initial reduction) } \\
\text { Exclusion criteria: intra-articular fracture, comminuted fracture (e.g. with associated distal ulnar fracture) } \\
\text {, previous fracture, mentally disturbed. } \\
\text { Classification: non stated (extra-articular) } \\
\text { Sex: all female (49) } \\
\text { Age: mean } 68 \text { years, range } 47 \text { - } 81 \text { years } \\
\text { Assigned: } 25 / 24 \text { [bone substitute / POP] } \\
\text { Assessed: } 24 / 23 \text { (2 years) }\end{array}$ \\
\hline
\end{tabular}


Schmalholz 1989 (Continued)

Timing of intervention: varied, second reduction 8 to 14 days after initial closed reduction for trial entry.
(1) Open reduction at 14-24 days (mean 18 days) post fracture (mostly regional anaesthesia)with bone
cement (methylmethacrylate)to fill dorsal bone deficiency and dorsal plaster for 2 weeks.
(2) Closed manipulation, mostly general anaesthesia, at $15-24$ days (mean 19 days) and low circular plaster
cast with arm in slight ulnar deviation and pronation for 4 weeks.

Length of follow up: 2 years; also assessed at 2 weeks, 1, 3, 6, 12 and 18 months.
(1) Functional: activities of daily living: combined score (Lidstrom 1959), mass grip strength, pain (own
scale - time when pain free), range of motion (flexion, extension, pronation, supination).
(2) Clinical: cosmetic results - patient satisfaction with appearance. Complications: median nerve palsy.
(3) Anatomical: X-ray pre/post reduction, 1, 6 months and 2 years. Dorsal angulation, axial compression,
disposition of cortical bone.

Duration of immobilisation in the control group supplied by Anders Schmalholtz

\section{Risk of bias}

\begin{tabular}{l|ll}
\hline Item & Author' judgement & Description \\
\hline Allocation concealment? & No & C - Inadequate \\
\hline
\end{tabular}

\section{Schmalholz 1990}

\begin{tabular}{ll}
\hline Methods & $\begin{array}{l}\text { Randomised by date of birth } \\
\text { Assessor blinding: not reported } \\
\text { Intention-to-treat analysis: likely, but interim data not presented for } 2 \text { patients who died } \\
\text { Loss to follow up: } 2 \text { (at } 1 \text { year) }\end{array}$ \\
\hline Participants & $\begin{array}{l}\text { Teaching hospital, Sweden } \\
50 \text { participants } \\
\text { Inclusion criteria: closed redisplaced unstable distal radial fracture, dorsal angulation } 30+\text { degrees and / } \\
\text { or axial compression } 5+\text { mm following second closed manipulation. Frykman type I and II fractures. } \\
\text { Exclusion criteria: intra-articular fracture, severely comminuted fracture, associated distal ulnar fracture } \\
\text { (except ulnar styloid), previous distal radial fracture, mentally disturbed patients. }\end{array}$ \\
$\begin{array}{l}\text { Classification: Frykman (I \& II: extra-articular) } \\
\text { Sex: } 46 \text { female (of } 48) \\
\text { Age: (of 48) median } 66-67 \text { years, range } 50 \text { - } 81 \text { years } \\
\text { Assigned: } 23 / 27 \text { [bone substitute / Ext-fix] } \\
\text { Assessed: } 23 / 25 \text { (at } 1 \text { year) }\end{array}$ \\
$\begin{array}{l}\text { Timing of intervention: varied, } 14 \text { to } 18 \text { days post injury (median } 16 \text { days). } \\
\text { (1) Open reduction at } 14-18 \text { days post fracture (mostly regional anaesthesia)with bone cement (methyl- } \\
\text { methacrylate)to fill dorsal bone deficiency and dorsal plaster for } 2 \text { weeks. } \\
\text { (2) Closed manipulation, mostly regional anaesthesia, and external fixation (2 pins in 2nd metacarpal and }\end{array}$ \\
$\begin{array}{l}\text { 2 in radial shaft) - with one bar Hoffman fixator for } 33 \text { to } 40 \text { days (5-6 weeks). } \\
\text { All had verbal and written instructions on exercises - those (1:8) patients unable to follow programme }\end{array}$ \\
\hline Interventions
\end{tabular}


Schmalholz 1990 (Continued)

themselves helped by physiotherapist.

\begin{tabular}{|c|c|c|}
\hline Outcomes & \multicolumn{2}{|c|}{$\begin{array}{l}\text { Length of follow up: } 1 \text { year after fixator removal; also assessed at plaster or fixator removal and } 1,3 \text { and } 6 \\
\text { months. } \\
\text { (1) Functional: activities of daily living: combined score (Lidstrom 1959), mass grip strength, pain (own } \\
\text { scale - pain free during specific activities), range of motion (dorsiflexion, volar flexion, pronation, supina- } \\
\text { tion). } \\
\text { (2) Clinical: cosmetic results - patient satisfaction with appearance. Complications: equipment failure (pin } \\
\text { loosening), pin track infection (all superficial), painful scar, fixator painful or uncomfortable, problems } \\
\text { with finger movements. } \\
\text { (3) Anatomical: X-ray post surgery, post plaster/ fixator removal reduction and } 1 \text { year. Dorsal angulation, } \\
\text { axial compression, disposition of cortical bone. }\end{array}$} \\
\hline Notes & \multicolumn{2}{|c|}{ Numbers of patients with finger problems supplied by Anders Schmalholtz } \\
\hline \multicolumn{3}{|l|}{ Risk of bias } \\
\hline Item & Authors' judgement & Description \\
\hline Allocation concealment? & No & C - Inadequate \\
\hline
\end{tabular}

Widman 2002

$\begin{array}{ll}\text { Methods } & \text { Randomised using a random numbers table } \\ \text { Assessor blinding: not reported } \\ \text { Intention-to-treat analysis: likely (full baseline data not provided for all participants) } \\ \text { Loss to follow up: } 3 \text { (at } 1 \text { year) }\end{array}$


Widman 2002 (Continued)

\begin{tabular}{|c|c|c|}
\hline Outcomes & \multicolumn{2}{|c|}{$\begin{array}{l}\text { Length of follow up: } 1 \text { year. } \\
\text { (1) Functional: severe impairment, grip strength, range of movement (flexion and extension, pronation } \\
\text { and supination). } \\
\text { (2) Clinical: Complications: malunion, pin track infection, CTS, tendon rupture (EPL), superficial painful } \\
\text { granuloma, serious donor site (graft) complication (bleed) } \\
\text { (3) Anatomical: X-ray at pre-op, post-op and } 1 \text { year. Dorsal angulation, radial shortening, severe malunion }\end{array}$} \\
\hline \multicolumn{3}{|l|}{ Notes } \\
\hline \multicolumn{3}{|l|}{ Risk of bias } \\
\hline Item & Authors' judgement & Description \\
\hline Allocation concealment? & Unclear & B - Unclear \\
\hline
\end{tabular}

$<$ : less than

$>$ : more than

A+E: accident and emergency

AO: Arbeitsgemeinschaft fur Osteosynthesefragen / Association for the Study of Internal Fixation (or ASIF)

CTS: carpal tunnel syndrome

DISI: dorsal intercalated segment instability

EPL: extensor pollicis longus (tendon)

Ext-fix: external fixation

K-wires: Kirschner wires

paraesthesia: numbness, tingling, "pins and needles" sensation

POP: plaster of Paris

ROM: range of movement (wrist and forearm)

RSD: reflex sympathetic dystrophy

VAS: visual analogue scale

VISI: volar intercalated segment instability

X-pins: crossed percutaneous pinning

References (listed above but not in Additional references)

* Lidstrom 1959

Lidstrom A. Fractures of the distal end of the radius. A clinical and statistical study of end results. Acta Orthopaedica Scandinavica Supplementum 1959; 41:5-118.

Characteristics of excluded studies [ordered by study ID]
Chapman 1997 A trial of 325 people (with 374 acute fractures)who were randomised to either a collagen-calcium phosphate graft material or autogenous bone graft. Our attempts to obtain further information on this trial, including separate data for patients with distal radial fractures, were unsuccessful. The contact author indicated that the raw data were with Zimmer.
Dickson 2002 A trial involving 38 people with various fractures, 6 of which were radial fractures, who were randomised to BoneSource hydroxyapatite cement versus autologous cancellous bone. Only 28 were followed up. Separate data were not presented for patients with distal radial fractures.


(Continued)

McQueen 2001 Contact trialist indicated that this study, listed in the National Research Register, was not started as the company withdrew the bone substitute.

Schmalholz 1988 Randomised trial comparing bone cement versus external fixation in 20 people with redisplaced Colles' fractures. Excluded as it reported surrogate outcomes only - no clinically relevant outcomes.

Wyrick 1999 We have been unable to obtain further information or any report of this trial, at one time commented on a website, that compared corraline hydroxyapite versus autogenous bone graft in the treatment of distal radius fractures.

Zimmermann 2003 Trial compared open reduction pin and screw fixation and filling the bone defect with calcium phosphate bone cement Norian SRS versus closed reduction and percutaneous pinning. This trial is excluded because this comparison is not covered in this review. 


\section{Characteristics of ongoing studies [ordered by study ID]}

\section{Barbier 2008}

\begin{tabular}{|c|c|}
\hline Trial name or title & Allomatrix injectable putty in distal radius fractures \\
\hline \multicolumn{2}{|l|}{ Methods } \\
\hline Participants & $\begin{array}{l}50 \text { patients with unstable fractures of the distal radius. } \\
\text { Inclusion: age } 18 \text { to } 70 \text { years, unstable distal radius fracture (types I, III and IV (Fernandez)), informed } \\
\text { consent. } \\
\text { Exclusion: Associated traumatic lesions, associated severe pathological conditions, pregnancy. }\end{array}$ \\
\hline Interventions & $\begin{array}{l}\text { After surgical reduction and stabilisation with percutaneous pinning alone or with external fixation bridging } \\
\text { the joint: } \\
\text { (1) ALLOMATRIX injectable putty; } \\
\text { (2) no additional graft. }\end{array}$ \\
\hline Outcomes & $\begin{array}{l}\text { Follow up: } 1 \text { year. } \\
\text { Primary outcome measures: hand ability: self-assessment questionnaire ABILHAND and DASH. } \\
\text { Secondary Outcome Measures: Bone mineral density, radiological evaluation, hand impairment (strength, } \\
\text { sensibility, mobility) } \\
\text { Also, failure (non-union, malunion, fracture instability, wrist stiffness)and complication (infection, drainage, } \\
\text { hardware failure, wound dehiscence)rates. }\end{array}$ \\
\hline Starting date & Start date: June 2005 Completion: June 2008 \\
\hline Contact information & $\begin{array}{l}\text { Dr Olivier Barbier, MD } \\
\text { Cliniques Universitaires St-Luc } \\
\text { Brussels } 1200 \\
\text { Belgium } \\
\text { Tel: + } 3227641111 \text { Ext. } 2523 \text { E-mail:olivier.barbier@orto.ucl.ac.be }\end{array}$ \\
\hline Notes & $\begin{array}{l}\text { At the end of the surgical reduction and stabilization of the fracture, the sequentially numbered randomization } \\
\text { envelope will be opened and the patient will receive the treatment listed within the envelope. }\end{array}$ \\
\hline
\end{tabular}

DASH: Disability of the Arm, Shoulder, and Hand questionnaire 
DATA AND ANALYSES

Comparison 1. Bone scaffolding (graft/substitute) versus plaster cast

\begin{tabular}{|c|c|c|c|c|}
\hline Outcome or subgroup title & $\begin{array}{l}\text { No. of } \\
\text { studies }\end{array}$ & $\begin{array}{l}\text { No. of } \\
\text { participants }\end{array}$ & Statistical method & Effect size \\
\hline 1 Functional gradings & 2 & & Risk Ratio (M-H, Fixed, 95\% CI) & Totals not selected \\
\hline 1.1 Not excellent & 2 & & Risk Ratio (M-H, Fixed, 95\% CI) & Not estimable \\
\hline 1.2 Fair or poor & 2 & & Risk Ratio (M-H, Fixed, 95\% CI) & Not estimable \\
\hline $\begin{array}{l}2 \text { Non recovery of full grip } \\
\text { strength }\end{array}$ & 1 & & Risk Ratio (M-H, Fixed, 95\% CI) & Totals not selected \\
\hline $\begin{array}{l}3 \text { Mass grip strength ( } \% \text { of normal } \\
\text { side) }\end{array}$ & 3 & & Mean Difference (IV, Fixed, 95\% CI) & Totals not selected \\
\hline 3.1 Bone graft & 1 & & Mean Difference (IV, Fixed, 95\% CI) & Not estimable \\
\hline 3.2 Norian SRS & 1 & & Mean Difference (IV, Fixed, 95\% CI) & Not estimable \\
\hline $\begin{array}{l}3.3 \text { Methylmethacrylate } \\
\text { cement }\end{array}$ & 1 & & Mean Difference (IV, Fixed, 95\% CI) & Not estimable \\
\hline $\begin{array}{l}4 \text { Pain at } 6 \text { months (VAS: } 0 \text { (none) } \\
\text { to } 100 \mathrm{~mm} \text { (unbearable)) }\end{array}$ & 1 & & Mean Difference (IV, Fixed, 95\% CI) & Totals not selected \\
\hline 5 Long term pain & 2 & & Risk Ratio (M-H, Fixed, 95\% CI) & Totals not selected \\
\hline $\begin{array}{l}\text { 5.1 Pain during lifting or } \\
\text { carrying }\end{array}$ & 1 & & Risk Ratio (M-H, Fixed, 95\% CI) & Not estimable \\
\hline 5.2 Radiocarpal pain & 1 & & Risk Ratio (M-H, Fixed, 95\% CI) & Not estimable \\
\hline 5.3 Radio-ulnar pain & 1 & & Risk Ratio (M-H, Fixed, 95\% CI) & Not estimable \\
\hline $\begin{array}{l}6 \text { Non-recovery of full range of } \\
\text { movement }\end{array}$ & 1 & & Risk Ratio (M-H, Fixed, 95\% CI) & Totals not selected \\
\hline 6.1 Flexion & 1 & & Risk Ratio (M-H, Fixed, 95\% CI) & Not estimable \\
\hline 6.2 Extension & 1 & & Risk Ratio (M-H, Fixed, 95\% CI) & Not estimable \\
\hline 6.3 Pronation & 1 & & Risk Ratio (M-H, Fixed, 95\% CI) & Not estimable \\
\hline 6.4 Supination & 1 & & Risk Ratio (M-H, Fixed, 95\% CI) & Not estimable \\
\hline $\begin{array}{l}7 \text { Range of movement (\% of } \\
\text { normal side) }\end{array}$ & 2 & & Mean Difference (IV, Fixed, 95\% CI) & Totals not selected \\
\hline 7.1 Flexion & 1 & & Mean Difference (IV, Fixed, 95\% CI) & Not estimable \\
\hline 7.2 Extension & 1 & & Mean Difference (IV, Fixed, 95\% CI) & Not estimable \\
\hline 7.3 Radial deviation & 1 & & Mean Difference (IV, Fixed, 95\% CI) & Not estimable \\
\hline 7.4 Ulnar deviation & 1 & & Mean Difference (IV, Fixed, 95\% CI) & Not estimable \\
\hline 7.5 Pronation & 1 & & Mean Difference (IV, Fixed, 95\% CI) & Not estimable \\
\hline 7.6 Supination & 1 & & Mean Difference (IV, Fixed, 95\% CI) & Not estimable \\
\hline 7.7 Flexion/extension & 1 & & Mean Difference (IV, Fixed, 95\% CI) & Not estimable \\
\hline $\begin{array}{l}7.8 \text { Overall range of } \\
\text { movement }\end{array}$ & 1 & & Mean Difference (IV, Fixed, 95\% CI) & Not estimable \\
\hline 8 Complications & 4 & & Risk Ratio (M-H, Fixed, 95\% CI) & Subtotals only \\
\hline 8.1 Recurrent instability & 1 & 60 & Risk Ratio (M-H, Fixed, 95\% CI) & $0.19[0.06,0.58]$ \\
\hline $\begin{array}{l}8.2 \text { Redisplacement resulting } \\
\text { in secondary treatment }\end{array}$ & 1 & 110 & Risk Ratio (M-H, Fixed, 95\% CI) & Not estimable \\
\hline $\begin{array}{l}\text { 8.3 Pin track or K-wire } \\
\text { infection }\end{array}$ & 1 & 60 & Risk Ratio (M-H, Fixed, 95\% CI) & $3.0[0.13,70.83]$ \\
\hline 8.4 Wound infection & 2 & 170 & Risk Ratio (M-H, Fixed, 95\% CI) & $5.0[0.25,99.95]$ \\
\hline 8.5 Tendon rupture & 3 & 188 & Risk Ratio (M-H, Fixed, 95\% CI) & $2.33[0.35,15.44]$ \\
\hline
\end{tabular}




\begin{tabular}{|c|c|c|c|c|}
\hline $\begin{array}{l}\text { 8.6 Carpal tunnel syndrome/ } \\
\text { median nerve compression }\end{array}$ & 3 & 188 & Risk Ratio (M-H, Fixed, 95\% CI) & $0.73[0.22,2.38]$ \\
\hline 8.7 Nerve palsy & 1 & 47 & Risk Ratio (M-H, Fixed, 95\% CI) & $2.88[0.12,67.29]$ \\
\hline $\begin{array}{l}8.8 \text { "Dorsal medial } \\
\text { neuropraxia" }\end{array}$ & 1 & 60 & Risk Ratio (M-H, Fixed, 95\% CI) & $3.0[0.13,70.83]$ \\
\hline $\begin{array}{l}8.9 \text { "Irritation of the distal } \\
\text { branch of the radial nerve" }\end{array}$ & 1 & 18 & Risk Ratio (M-H, Fixed, 95\% CI) & $0.24[0.01,4.47]$ \\
\hline $\begin{array}{l}8.10 \text { Reflex sympathetic } \\
\text { dystrophy }\end{array}$ & 2 & 170 & Risk Ratio (M-H, Fixed, 95\% CI) & $0.8[0.22,2.87]$ \\
\hline 8.11 Refracture & 1 & 110 & Risk Ratio (M-H, Fixed, 95\% CI) & $3.0[0.12,72.08]$ \\
\hline $\begin{array}{l}8.12 \text { Intra-articular deposit } \\
\text { of bone cement (surgically } \\
\text { removed) }\end{array}$ & 1 & 110 & Risk Ratio (M-H, Fixed, 95\% CI) & $3.0[0.12,72.08]$ \\
\hline $\begin{array}{l}8.13 \text { Post-operative pain: due } \\
\text { to extrusion of bone cement } \\
\text { into soft-tissues? }\end{array}$ & 1 & 18 & Risk Ratio (M-H, Fixed, 95\% CI) & $8.56[0.51,144.86]$ \\
\hline $\begin{array}{l}8.14 \text { Persistent soft-tissue } \\
\text { deposit of bone cement }\end{array}$ & 1 & 110 & Risk Ratio (M-H, Fixed, 95\% CI) & $37.0[2.29,599.09]$ \\
\hline Anatomical displacement & 2 & & Mean Difference (IV, Fixed, 95\% CI) & Totals not selected \\
\hline $\begin{array}{l}9.1 \text { Loss in radial length } \\
\text { (radial shortening) (mm) }\end{array}$ & 2 & & Mean Difference (IV, Fixed, 95\% CI) & Not estimable \\
\hline 0 Anatomical measurements & 2 & & Mean Difference (IV, Fixed, 95\% CI) & Totals not selected \\
\hline $\begin{array}{l}10.1 \text { Dorsal angulation } \\
\text { (degrees) }\end{array}$ & 2 & & Mean Difference (IV, Fixed, 95\% CI) & Not estimable \\
\hline $\begin{array}{l}1 \text { Deformity (cosmetic and } \\
\text { structural) }\end{array}$ & 4 & & Risk Ratio (M-H, Fixed, 95\% CI) & Subtotals only \\
\hline 11.1 Carpal collapse & 1 & 60 & Risk Ratio (M-H, Fixed, 95\% CI) & $0.79[0.43,1.44]$ \\
\hline 11.2 Malunion & 2 & 170 & Risk Ratio (M-H, Fixed, 95\% CI) & $0.47[0.30,0.71]$ \\
\hline $\begin{array}{l}11.3 \text { Dissatisfaction with wrist } \\
\text { appearance }\end{array}$ & 1 & 47 & Risk Ratio (M-H, Fixed, 95\% CI) & $0.03[0.00,0.49]$ \\
\hline $\begin{array}{l}11.4 \text { Radial osteotomy } \\
\text { performed: painful deformed } \\
\text { wrist }\end{array}$ & 1 & 18 & Risk Ratio (M-H, Fixed, 95\% CI) & $0.41[0.02,8.84]$ \\
\hline
\end{tabular}

\section{Comparison 2. Bone substitute versus control (plaster or external fixation)}

\begin{tabular}{|c|c|c|c|c|}
\hline Outcome or subgroup title & $\begin{array}{l}\text { No. of } \\
\text { studies }\end{array}$ & $\begin{array}{c}\text { No. of } \\
\text { participants }\end{array}$ & Statistical method & Effect size \\
\hline 1 Unsuccessful functional outcome & 1 & & Risk Ratio (M-H, Fixed, 95\% CI) & Totals not selected \\
\hline 2 Grip strength (\% or normal side) & 1 & & Mean Difference (IV, Fixed, 95\% CI) & Totals not selected \\
\hline 3 Pain & 1 & & Risk Ratio (M-H, Fixed, 95\% CI) & Totals not selected \\
\hline $\begin{array}{l}4 \text { Range of movement (\% of } \\
\text { normal side) }\end{array}$ & 1 & & Mean Difference (IV, Fixed, 95\% CI) & Totals not selected \\
\hline 4.1 Flexion & 1 & & Mean Difference (IV, Fixed, 95\% CI) & Not estimable \\
\hline 4.2 Extension & 1 & & Mean Difference (IV, Fixed, 95\% CI) & Not estimable \\
\hline 4.3 Pronation & 1 & & Mean Difference (IV, Fixed, 95\% CI) & Not estimable \\
\hline 4.4 Supination & 1 & & Mean Difference (IV, Fixed, 95\% CI) & Not estimable \\
\hline
\end{tabular}

Bone grafts and bone substitutes for treating distal radial fractures in adults (Review)

Copyright (C) 2009 The Cochrane Collaboration. Published by John Wiley \& Sons, Ltd. 
Not estimable

Risk Ratio (M-H, Fixed, 95\% CI)

Totals not selected

Risk Ratio (M-H, Fixed, 95\% CI) Risk Ratio (M-H, Fixed, 95\% CI) Risk Ratio (M-H, Fixed, 95\% CI) Risk Ratio (M-H, Fixed, 95\% CI) Risk Ratio (M-H, Fixed, 95\% CI) Risk Ratio (M-H, Fixed, 95\% CI)

Risk Ratio (M-H, Fixed, 95\% CI) Risk Ratio (M-H, Fixed, 95\% CI) Risk Ratio (M-H, Fixed, 95\% CI) Risk Ratio (M-H, Fixed, 95\% CI) Risk Ratio (M-H, Fixed, 95\% CI) Risk Ratio (M-H, Fixed, 95\% CI)

Risk Ratio (M-H, Fixed, 95\% CI)

Risk Ratio (M-H, Fixed, 95\% CI) Risk Ratio (M-H, Fixed, 95\% CI)

Risk Ratio (M-H, Fixed, 95\% CI) Risk Ratio (M-H, Fixed, 95\% CI)

Risk Ratio (M-H, Fixed, 95\% CI)

Risk Ratio (M-H, Fixed, 95\% CI) Risk Ratio (M-H, Fixed, 95\% CI)

6.15 Other complica thumb and ulna fractures, ulnar styloid non-union, pin problems

7 Anatomical measurements 7.1 Loss of radial length $(\mathrm{mm})$ 7.2 Loss of radial angle (degrees)

7.3 Volar/dorsal angle change (degrees)

8 Unsuccessful radiographic outcome measures

8.1 Unsuccessful radiographic outcome: overall

8.2 Radial length loss (5 $\mathrm{mm}$ or more difference from contralateral side)
Mean Difference (IV, Fixed, 95\% CI) Mean Difference (IV, Fixed, 95\% CI) Mean Difference (IV, Fixed, 95\% CI)

Mean Difference (IV, Fixed, 95\% CI)

Risk Ratio (M-H, Fixed, 95\% CI)

Risk Ratio (M-H, Fixed, 95\% CI)

Risk Ratio (M-H, Fixed, 95\% CI)
Not estimable

Not estimable

Not estimable

Not estimable

Totals not selected

Not estimable

Not estimable

Not estimable

Not estimable

Not estimable

Not estimable

Not estimable

Not estimable

Not estimable

Not estimable

Not estimable

Not estimable

Not estimable

Not estimable

Totals not selected Not estimable

Not estimable

Not estimable

Totals not selected

Not estimable

Not estimable
Not estimable 


\begin{tabular}{|c|c|c|c|}
\hline $\begin{array}{l}8.3 \text { Volar/dorsal angle change } \\
\text { ( }>20 \text { degrees change) }\end{array}$ & 1 & Risk Ratio (M-H, Fixed, 95\% CI) & Not estimable \\
\hline $\begin{array}{l}8.4 \text { Dorsal angle }(>/=10 \\
\text { degrees) }\end{array}$ & 1 & Risk Ratio (M-H, Fixed, 95\% CI) & Not estimable \\
\hline $\begin{array}{l}\text { 8.5 Articular step off }(>/= \\
2 \mathrm{~mm})\end{array}$ & 1 & Risk Ratio (M-H, Fixed, 95\% CI) & Not estimable \\
\hline 8.6 Non healed fracture & 1 & Risk Ratio (M-H, Fixed, 95\% CI) & Not estimable \\
\hline
\end{tabular}

Comparison 3. Bone graft, external fixation then plaster cast versus external fixation

\begin{tabular}{|c|c|c|c|c|}
\hline Outcome or subgroup title & $\begin{array}{l}\text { No. of } \\
\text { studies }\end{array}$ & $\begin{array}{c}\text { No. of } \\
\text { participants }\end{array}$ & Statistical method & Effect size \\
\hline $\begin{array}{l}1 \text { Poor function and grip strength } \\
\text { (at } 1 \text { year) }\end{array}$ & 1 & & Risk Ratio (M-H, Fixed, 95\% CI) & Totals not selected \\
\hline $\begin{array}{l}1.1 \text { Poor function }=<50 \% \text { of } \\
\text { normal side grip and range of } \\
\text { movement }\end{array}$ & 1 & & Risk Ratio (M-H, Fixed, 95\% CI) & Not estimable \\
\hline $\begin{array}{l}1.2 \text { Grip strength }<60 \% \text { of } \\
\text { normal side }\end{array}$ & 1 & & Risk Ratio (M-H, Fixed, 95\% CI) & Not estimable \\
\hline $\begin{array}{l}2 \text { Mass grip strength (\% of normal } \\
\text { side) }\end{array}$ & 1 & & Mean Difference (IV, Fixed, 95\% CI) & Totals not selected \\
\hline $\begin{array}{l}3 \text { Range of movement (\% of } \\
\text { normal side) }\end{array}$ & 1 & & Mean Difference (IV, Fixed, 95\% CI) & Totals not selected \\
\hline 3.1 Flexion and extension & 1 & & Mean Difference (IV, Fixed, 95\% CI) & Not estimable \\
\hline 3.2 Pronation and supination & 1 & & Mean Difference (IV, Fixed, 95\% CI) & Not estimable \\
\hline 4 Complications & 1 & & Risk Ratio (M-H, Fixed, 95\% CI) & Totals not selected \\
\hline 4.1 Pin track infection & 1 & & Risk Ratio (M-H, Fixed, 95\% CI) & Not estimable \\
\hline 4.2 Tendon rupture & 1 & & Risk Ratio (M-H, Fixed, 95\% CI) & Not estimable \\
\hline 4.3 Carpal tunnel syndrome & 1 & & Risk Ratio (M-H, Fixed, 95\% CI) & Not estimable \\
\hline $\begin{array}{l}\text { 4.4 Superficial painful } \\
\text { granuloma }\end{array}$ & 1 & & Risk Ratio (M-H, Fixed, 95\% CI) & Not estimable \\
\hline $\begin{array}{l}4.5 \text { Serious donor site } \\
\text { complication (bleed) }\end{array}$ & 1 & & Risk Ratio (M-H, Fixed, 95\% CI) & Not estimable \\
\hline 5 Anatomical measurements & 1 & & Mean Difference (IV, Fixed, 95\% CI) & Totals not selected \\
\hline $\begin{array}{l}5.1 \text { Dorsal angulation } \\
\text { (degrees) }\end{array}$ & 1 & & Mean Difference (IV, Fixed, 95\% CI) & Not estimable \\
\hline $\begin{array}{l}\text { 5.2 Axial radial shortening } \\
(\mathrm{mm})\end{array}$ & 1 & & Mean Difference (IV, Fixed, 95\% CI) & Not estimable \\
\hline 6 Deformity (severe malunion) & 1 & & Risk Ratio (M-H, Fixed, 95\% CI) & Totals not selected \\
\hline
\end{tabular}


Comparison 4. Bone substitute versus percutaneous pinning

\begin{tabular}{|c|c|c|c|c|}
\hline Outcome or subgroup title & $\begin{array}{l}\text { No. of } \\
\text { studies }\end{array}$ & $\begin{array}{c}\text { No. of } \\
\text { participants }\end{array}$ & Statistical method & Effect size \\
\hline 1 Palmar flexion (degrees) & 1 & & Mean Difference (IV, Fixed, 95\% CI) & Totals not selected \\
\hline 2 Complications & 1 & & Risk Ratio (M-H, Fixed, 95\% CI) & Totals not selected \\
\hline
\end{tabular}

Comparison 5. Bone scaffolding (graft/substitute) versus external fixation

\begin{tabular}{|c|c|c|c|c|}
\hline Outcome or subgroup title & $\begin{array}{l}\text { No. of } \\
\text { studies }\end{array}$ & $\begin{array}{c}\text { No. of } \\
\text { participants }\end{array}$ & Statistical method & Effect size \\
\hline 1 Functional gradings & 1 & & Risk Ratio (M-H, Fixed, 95\% CI) & Totals not selected \\
\hline 1.1 Not excellent & 1 & & Risk Ratio (M-H, Fixed, 95\% CI) & Not estimable \\
\hline 1.2 Fair or poor & 1 & & Risk Ratio (M-H, Fixed, 95\% CI) & Not estimable \\
\hline $\begin{array}{l}2 \text { Non recovery of full grip } \\
\text { strength }\end{array}$ & 1 & & Risk Ratio (M-H, Fixed, 95\% CI) & Totals not selected \\
\hline $\begin{array}{l}3 \text { Mass grip strength (\% of normal } \\
\text { side) }\end{array}$ & 1 & & Mean Difference (IV, Fixed, 95\% CI) & Totals not selected \\
\hline $\begin{array}{l}4 \text { Persistent pain (during carrying } \\
\text { or lifting) }\end{array}$ & 1 & & Risk Ratio (M-H, Fixed, 95\% CI) & Totals not selected \\
\hline 4.1 At 2 months & 1 & & Risk Ratio (M-H, Fixed, 95\% CI) & Not estimable \\
\hline 4.2 At 3 months & 1 & & Risk Ratio (M-H, Fixed, 95\% CI) & Not estimable \\
\hline 4.3 At 6 months & 1 & & Risk Ratio (M-H, Fixed, 95\% CI) & Not estimable \\
\hline 4.4 At 12 months & 1 & & Risk Ratio (M-H, Fixed, 95\% CI) & Not estimable \\
\hline $\begin{array}{l}5 \text { Non-recovery of full range of } \\
\text { movement }\end{array}$ & 1 & & Risk Ratio (M-H, Fixed, 95\% CI) & Totals not selected \\
\hline 5.1 Flexion & 1 & & Risk Ratio (M-H, Fixed, 95\% CI) & Not estimable \\
\hline 5.2 Extension & 1 & & Risk Ratio (M-H, Fixed, 95\% CI) & Not estimable \\
\hline 5.3 Pronation & 1 & & Risk Ratio (M-H, Fixed, 95\% CI) & Not estimable \\
\hline 5.4 Supination & 1 & & Risk Ratio (M-H, Fixed, 95\% CI) & Not estimable \\
\hline $\begin{array}{l}6 \text { Range of movement (\% of } \\
\text { normal side) }\end{array}$ & 1 & & Mean Difference (IV, Fixed, 95\% CI) & Totals not selected \\
\hline 6.1 Flexion/extension & 1 & & Mean Difference (IV, Fixed, 95\% CI) & Not estimable \\
\hline $\begin{array}{l}6.2 \text { Overall range of } \\
\text { movement }\end{array}$ & 1 & & Mean Difference (IV, Fixed, 95\% CI) & Not estimable \\
\hline 7 Complications & 3 & & Risk Ratio (M-H, Fixed, 95\% CI) & Subtotals only \\
\hline 7.1 Recurrent instability & 1 & 60 & Risk Ratio (M-H, Fixed, 95\% CI) & $0.21[0.07,0.67]$ \\
\hline $\begin{array}{l}7.2 \text { Pin loosening / pin track } \\
\text { infection requiring early fixator } \\
\text { removal }\end{array}$ & 2 & 138 & Risk Ratio (M-H, Fixed, 95\% CI) & $0.29[0.04,2.35]$ \\
\hline $\begin{array}{l}\text { 7.3 Pin track or K-wire } \\
\text { infection }\end{array}$ & 3 & 178 & Risk Ratio (M-H, Fixed, 95\% CI) & $0.18[0.04,0.77]$ \\
\hline $\begin{array}{l}7.4 \text { Scar adhesion to bone } \\
\text { requiring surgical treatment }\end{array}$ & 1 & 48 & Risk Ratio (M-H, Fixed, 95\% CI) & $0.36[0.02,8.45]$ \\
\hline 7.5 Skin adhesions & 1 & 40 & Risk Ratio (M-H, Fixed, 95\% CI) & $0.14[0.01,2.60]$ \\
\hline
\end{tabular}




\begin{tabular}{|c|c|c|c|c|}
\hline $\begin{array}{l}7.6 \text { Uncomfortable / painful } \\
\text { fixator }\end{array}$ & 1 & 48 & Risk Ratio (M-H, Fixed, 95\% CI) & $0.04[0.00,0.64]$ \\
\hline 7.7 Wound infection & 1 & 90 & Risk Ratio (M-H, Fixed, 95\% CI) & $9.84[0.49,198.69]$ \\
\hline 7.8 Tendon rupture & 2 & 130 & Risk Ratio (M-H, Fixed, 95\% CI) & $4.17[0.46,37.67]$ \\
\hline 7.9 Carpal tunnel syndrome & 2 & 130 & Risk Ratio (M-H, Fixed, 95\% CI) & $2.47[0.60,10.13]$ \\
\hline $\begin{array}{l}7.10 \text { "Dorsal medial } \\
\text { neuropraxia" }\end{array}$ & 1 & 90 & Risk Ratio (M-H, Fixed, 95\% CI) & $2.0[0.13,30.88]$ \\
\hline $\begin{array}{l}\text { 7.11 Reflex sympathetic } \\
\text { dystrophy }\end{array}$ & 1 & 90 & Risk Ratio (M-H, Fixed, 95\% CI) & $0.29[0.04,2.22]$ \\
\hline 7.12 Swollen wrist & 1 & 40 & Risk Ratio (M-H, Fixed, 95\% CI) & $0.11[0.01,1.94]$ \\
\hline 7.13 Persistent finger stiffness & 2 & 88 & Risk Ratio (M-H, Fixed, 95\% CI) & $0.26[0.03,2.21]$ \\
\hline 8 Anatomical displacement & 1 & & Mean Difference (IV, Fixed, 95\% CI) & Totals not selected \\
\hline $\begin{array}{l}\text { 8.1 Loss in radial length } \\
\text { (radial shortening) (mm) }\end{array}$ & 1 & & Mean Difference (IV, Fixed, 95\% CI) & Not estimable \\
\hline 9 Anatomical measurements & 1 & & Mean Difference (IV, Fixed, 95\% CI) & Totals not selected \\
\hline $\begin{array}{l}\text { 9.1 Dorsal angulation } \\
\text { (degrees) }\end{array}$ & 1 & & Mean Difference (IV, Fixed, 95\% CI) & Not estimable \\
\hline 10 Long term redisplacement & 1 & & Risk Ratio (M-H, Fixed, 95\% CI) & Totals not selected \\
\hline $\begin{array}{l}10.1 \text { Increase in dorsal } \\
\text { angulation }>5 \text { degrees at last } \\
\text { follow up }\end{array}$ & 1 & & Risk Ratio (M-H, Fixed, 95\% CI) & Not estimable \\
\hline $\begin{array}{l}10.2 \text { Radial shortening by } 1 \\
\mathrm{~mm} \text { at last follow up }\end{array}$ & 1 & & Risk Ratio (M-H, Fixed, 95\% CI) & Not estimable \\
\hline $\begin{array}{l}11 \text { Deformity (cosmetic and } \\
\text { structural) }\end{array}$ & 2 & & Risk Ratio (M-H, Fixed, 95\% CI) & Totals not selected \\
\hline 11.1 Carpal collapse & 1 & & Risk Ratio (M-H, Fixed, 95\% CI) & Not estimable \\
\hline 11.2 Malunion & 1 & & Risk Ratio (M-H, Fixed, 95\% CI) & Not estimable \\
\hline $\begin{array}{l}11.3 \text { Dissatisfaction with wrist } \\
\text { appearance for more than } 3 \\
\text { months }\end{array}$ & 1 & & Risk Ratio (M-H, Fixed, 95\% CI) & Not estimable \\
\hline
\end{tabular}

Comparison 6. Bone allograft versus autograft

\begin{tabular}{|c|c|c|c|c|}
\hline Outcome or subgroup title & $\begin{array}{l}\text { No. of } \\
\text { studies }\end{array}$ & $\begin{array}{c}\text { No. of } \\
\text { participants }\end{array}$ & Statistical method & Effect size \\
\hline $\begin{array}{l}1 \text { Moderate or severe restrictions } \\
\text { in everyday life }\end{array}$ & 1 & & Risk Ratio (M-H, Fixed, 95\% CI) & Totals not selected \\
\hline 2 Functional gradings & 1 & & Risk Ratio (M-H, Fixed, 95\% CI) & Totals not selected \\
\hline 2.1 Not excellent & 1 & & Risk Ratio (M-H, Fixed, 95\% CI) & Not estimable \\
\hline 2.2 Only fair (or poor) & 1 & & Risk Ratio (M-H, Fixed, 95\% CI) & Not estimable \\
\hline $\begin{array}{l}3 \text { Grip strength (\% of normal } \\
\text { hand) }\end{array}$ & 1 & & Mean Difference (IV, Fixed, 95\% CI) & Totals not selected \\
\hline $\begin{array}{l}4 \text { Discomforting or worse wrist } \\
\text { pain }\end{array}$ & 1 & & Risk Ratio (M-H, Fixed, 95\% CI) & Totals not selected \\
\hline 5 Range of movement (degrees) & 1 & & Mean Difference (IV, Fixed, 95\% CI) & Totals not selected \\
\hline 5.1 Flexion & 0 & & Mean Difference (IV, Fixed, 95\% CI) & Not estimable \\
\hline 5.2 Extension & 1 & & Mean Difference (IV, Fixed, 95\% CI) & Not estimable \\
\hline 5.3 Radial deviation & 1 & & Mean Difference (IV, Fixed, 95\% CI) & Not estimable \\
\hline
\end{tabular}

Bone grafts and bone substitutes for treating distal radial fractures in adults (Review)

Copyright @ 2009 The Cochrane Collaboration. Published by John Wiley \& Sons, Ltd. 


\subsection{Ulnar deviation \\ 5.5 Pronation \\ 5.6 Supination}

6 Complications

6.1 Local or systematic

immunogenic reactions

6.2 Plate removal because of limited wrist mobility

6.3 Iatrogenic injury (donorsite: tear off of the anterior superior iliac spine)

6.4 Short-term (<2 weeks)

post-operative pain (from iliaccrest harvesting)

6.5 Haematoma (donor site)

6.6 Discomforting

paraesthesias (lower limb) at 1

year

6.7 Continuing pain (mild or discomforting) from donor site at 1 year

7 Dissatisfaction (only poor or fair rating of treatment outcome)

8 Anatomical measurements (1 year)

8.1 Volar tilt (degrees)

8.2 Radial inclination (degrees)

8.3 Radial length (mm)

8.4 Ulnar variance $(\mathrm{mm})$

9 Anatomical outcomes

9.1 Dorsal tilt

9.2 Ulnar variance $>5 \mathrm{~mm}$

9.3 Articular incongruence

(all $<2 \mathrm{~mm}$ )

10 Length of operating (minutes)

11 Length of hospital stay (days)
Mean Difference (IV, Fixed, 95\% CI)

Mean Difference (IV, Fixed, 95\% CI)

Mean Difference (IV, Fixed, 95\% CI)

Risk Ratio (M-H, Fixed, 95\% CI)

Risk Ratio (M-H, Fixed, 95\% CI)

Risk Ratio (M-H, Fixed, 95\% CI)

Risk Ratio (M-H, Fixed, 95\% CI)

Risk Ratio (M-H, Fixed, 95\% CI)

Risk Ratio (M-H, Fixed, 95\% CI)

Risk Ratio (M-H, Fixed, 95\% CI)

Risk Ratio (M-H, Fixed, 95\% CI)

Risk Ratio (M-H, Fixed, 95\% CI)

Mean Difference (IV, Fixed, 95\% CI)

Mean Difference (IV, Fixed, 95\% CI)

Mean Difference (IV, Fixed, 95\% CI)

Mean Difference (IV, Fixed, 95\% CI)

Mean Difference (IV, Fixed, 95\% CI)

Risk Ratio (M-H, Fixed, 95\% CI)

Risk Ratio (M-H, Fixed, 95\% CI)

Risk Ratio (M-H, Fixed, 95\% CI)

Risk Ratio (M-H, Fixed, 95\% CI)

Mean Difference (IV, Fixed, 95\% CI)

Mean Difference (IV, Fixed, 95\% CI)
Not estimable

Not estimable

Not estimable

Totals not selected

Not estimable

Not estimable

Not estimable

Not estimable

Not estimable

Not estimable

Not estimable

Totals not selected

Totals not selected

Not estimable

Not estimable

Not estimable

Not estimable

Totals not selected

Not estimable

Not estimable

Not estimable

Totals not selected

Totals not selected 
Analysis I.I. Comparison I Bone scaffolding (graft/substitute) versus plaster cast, Outcome I Functional gradings.

Review: Bone grafts and bone substitutes for treating distal radial fractures in adults

Comparison: I Bone scaffolding (graft/substitute) versus plaster cast

Outcome: I Functional gradings

\begin{tabular}{|c|c|c|c|c|}
\hline \multirow[t]{2}{*}{ Study or subgroup } & Graft / substitute & Plaster cast & Risk Ratio & Risk Ratio \\
\hline & $\mathrm{n} / \mathrm{N}$ & $\mathrm{n} / \mathrm{N}$ & M-H,Fixed,95\% Cl & M-H,Fixed,95\% Cl \\
\hline \multicolumn{5}{|l|}{ I Not excellent } \\
\hline Sanchez-Sotelo 2000 & $25 / 55$ & $38 / 55$ & + & $0.66[0.47,0.92]$ \\
\hline Schmalholz 1989 & $18 / 24$ & $23 / 23$ & + & $0.76[0.59,0.96]$ \\
\hline \multicolumn{5}{|l|}{2 Fair or poor } \\
\hline Sanchez-Sotelo 2000 & $10 / 55$ & $25 / 55$ & + & $0.40[0.21,0.75]$ \\
\hline Schmalholz 1989 & $1 / 24$ & $21 / 23$ & $\longrightarrow$ & $0.05[0.01,0.31]$ \\
\hline
\end{tabular}

$0.0010 .010 .1 \quad 1 \quad 10 \quad 100 \quad 1000$

Favours scaffolding Favours cast only

Analysis I.2. Comparison I Bone scaffolding (graft/substitute) versus plaster cast, Outcome 2 Non recovery of full grip strength.

Review: Bone grafts and bone substitutes for treating distal radial fractures in adults

Comparison: I Bone scaffolding (graft/substitute) versus plaster cast

Outcome: 2 Non recovery of full grip strength

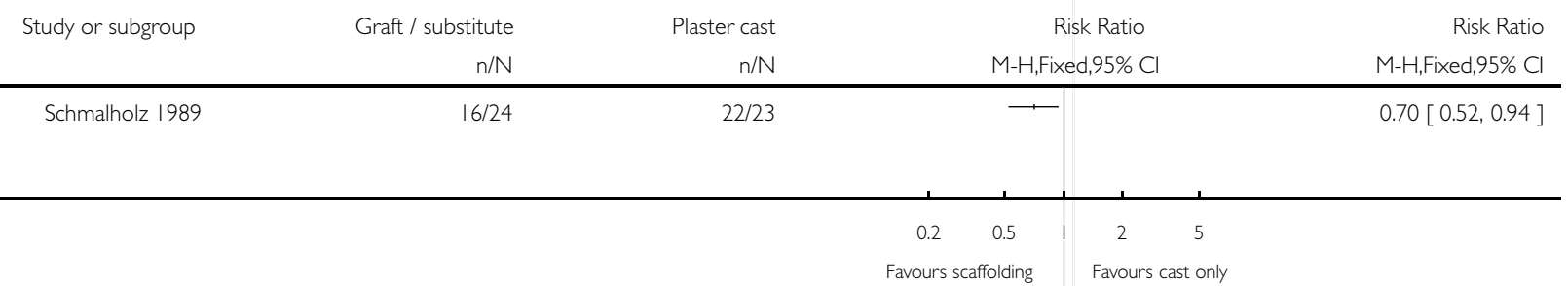


Analysis I.3. Comparison I Bone scaffolding (graft/substitute) versus plaster cast, Outcome 3 Mass grip strength (\% of normal side).

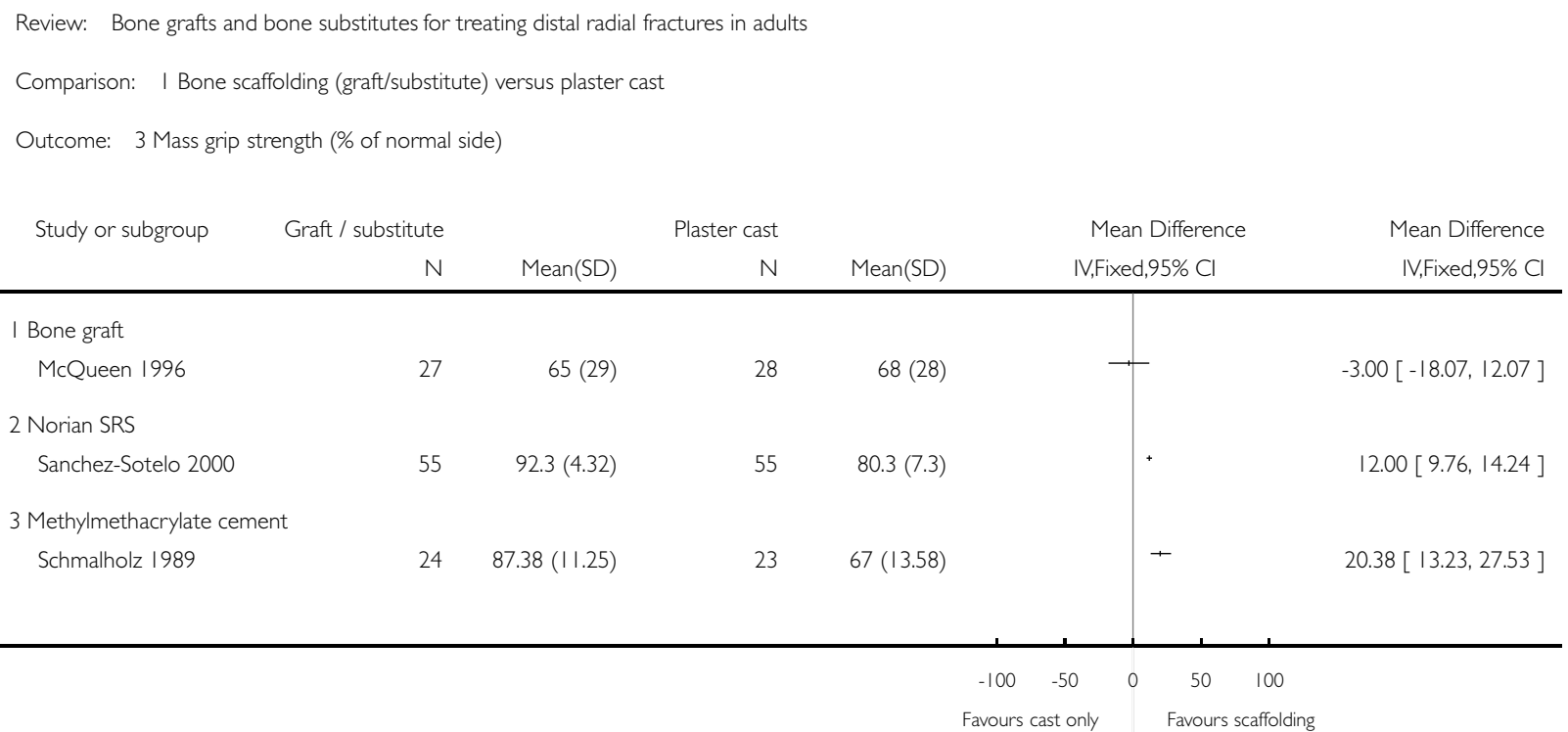

\section{Analysis I.4. Comparison I Bone scaffolding (graft/substitute) versus plaster cast, Outcome 4 Pain at 6} months (VAS: 0 (none) to $100 \mathrm{~mm}$ (unbearable)).

Review: Bone grafts and bone substitutes for treating distal radial fractures in adults

Comparison: I Bone scaffolding (graft/substitute) versus plaster cast

Outcome: 4 Pain at 6 months (VAS: 0 (none) to $100 \mathrm{~mm}$ (unbearable))

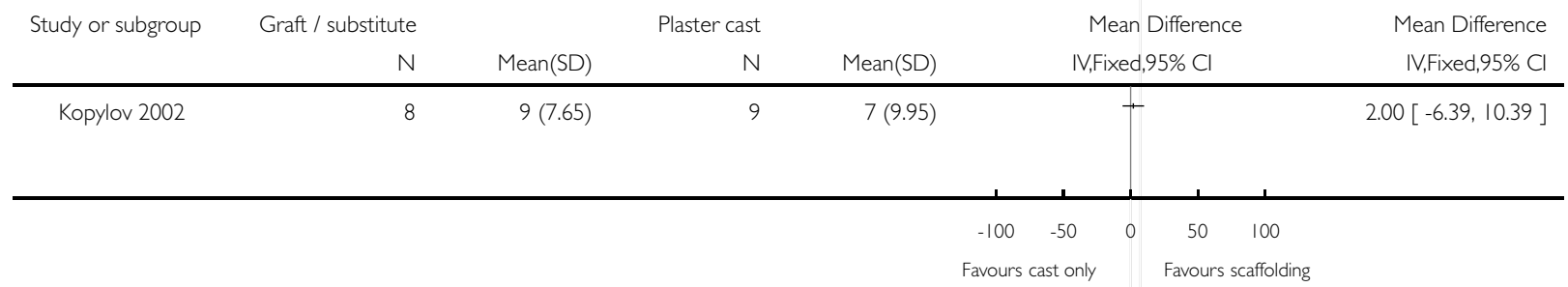


Analysis I.5. Comparison I Bone scaffolding (graft/substitute) versus plaster cast, Outcome 5 Long term pain.

Review: Bone grafts and bone substitutes for treating distal radial fractures in adults

Comparison: I Bone scaffolding (graft/substitute) versus plaster cast

Outcome: 5 Long term pain

\begin{tabular}{|c|c|c|c|c|}
\hline Study or subgroup & $\begin{array}{r}\text { Graft / substitute } \\
n / N\end{array}$ & $\begin{array}{r}\text { Plaster cast } \\
\mathrm{n} / \mathrm{N}\end{array}$ & $\begin{array}{c}\text { Risk Ratio } \\
\text { M-H,Fixed,95\% Cl }\end{array}$ & $\begin{array}{r}\text { Risk Ratio } \\
\text { M-H.Fixed.95\% Cl }\end{array}$ \\
\hline \multicolumn{5}{|c|}{ I Pain during lifting or carrying } \\
\hline Schmalholz 1989 & $0 / 24$ & $14 / 23$ & - & $0.03[0.00,0.52]$ \\
\hline \multicolumn{5}{|l|}{2 Radiocarpal pain } \\
\hline Sanchez-Sotelo 2000 & $7 / 55$ & $15 / 55$ & $\rightarrow$ & $0.47[0.21,1.05]$ \\
\hline \multicolumn{5}{|l|}{3 Radio-ulnar pain } \\
\hline Sanchez-Sotelo 2000 & $6 / 55$ & $17 / 55$ & + & $0.35[0.15,0.83]$ \\
\hline
\end{tabular}

Analysis I.6. Comparison I Bone scaffolding (graft/substitute) versus plaster cast, Outcome 6 Nonrecovery of full range of movement.

Review: Bone grafts and bone substitutes for treating distal radial fractures in adults

Comparison: I Bone scaffolding (graft/substitute) versus plaster cast

Outcome: 6 Non-recovery of full range of movement

Study or subgroup $\quad$ Graft / substitute $\quad$ Plaster cast $\quad$ Risk Ratio

$\mathrm{n} / \mathrm{N} \quad \mathrm{n} / \mathrm{N}$
M-H,Fixed,95\% Cl M-H,Fixed,95\% Cl

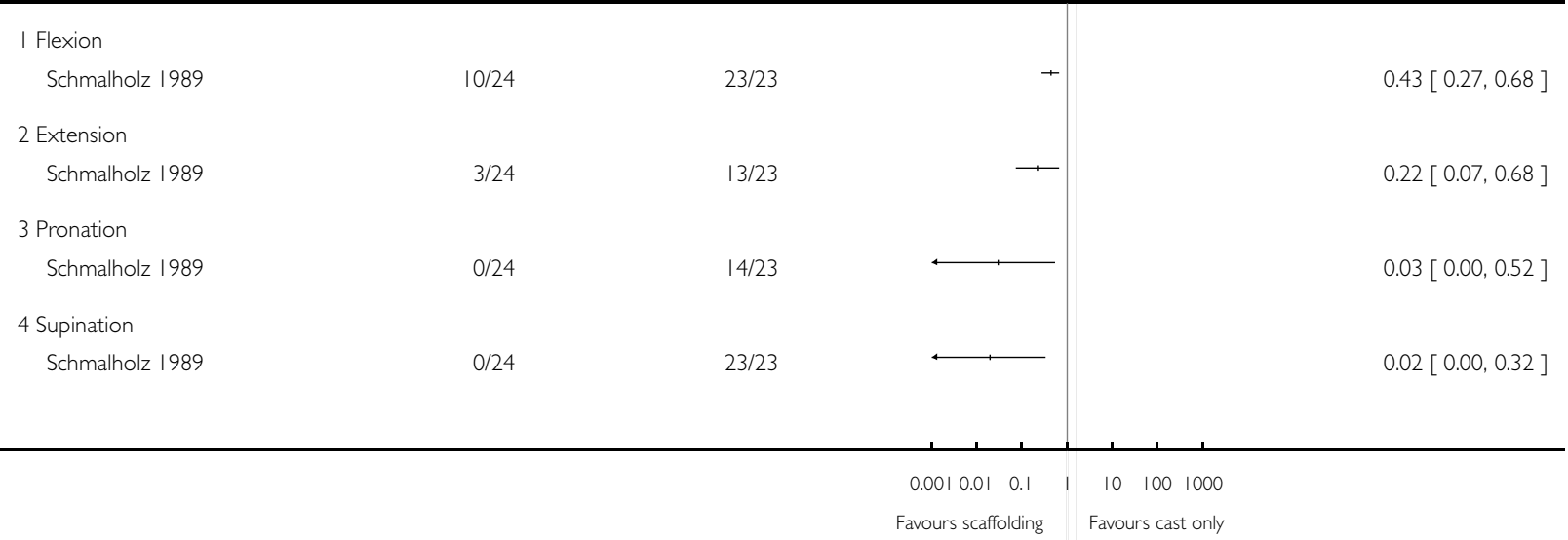


Analysis I.7. Comparison I Bone scaffolding (graft/substitute) versus plaster cast, Outcome 7 Range of movement (\% of normal side).

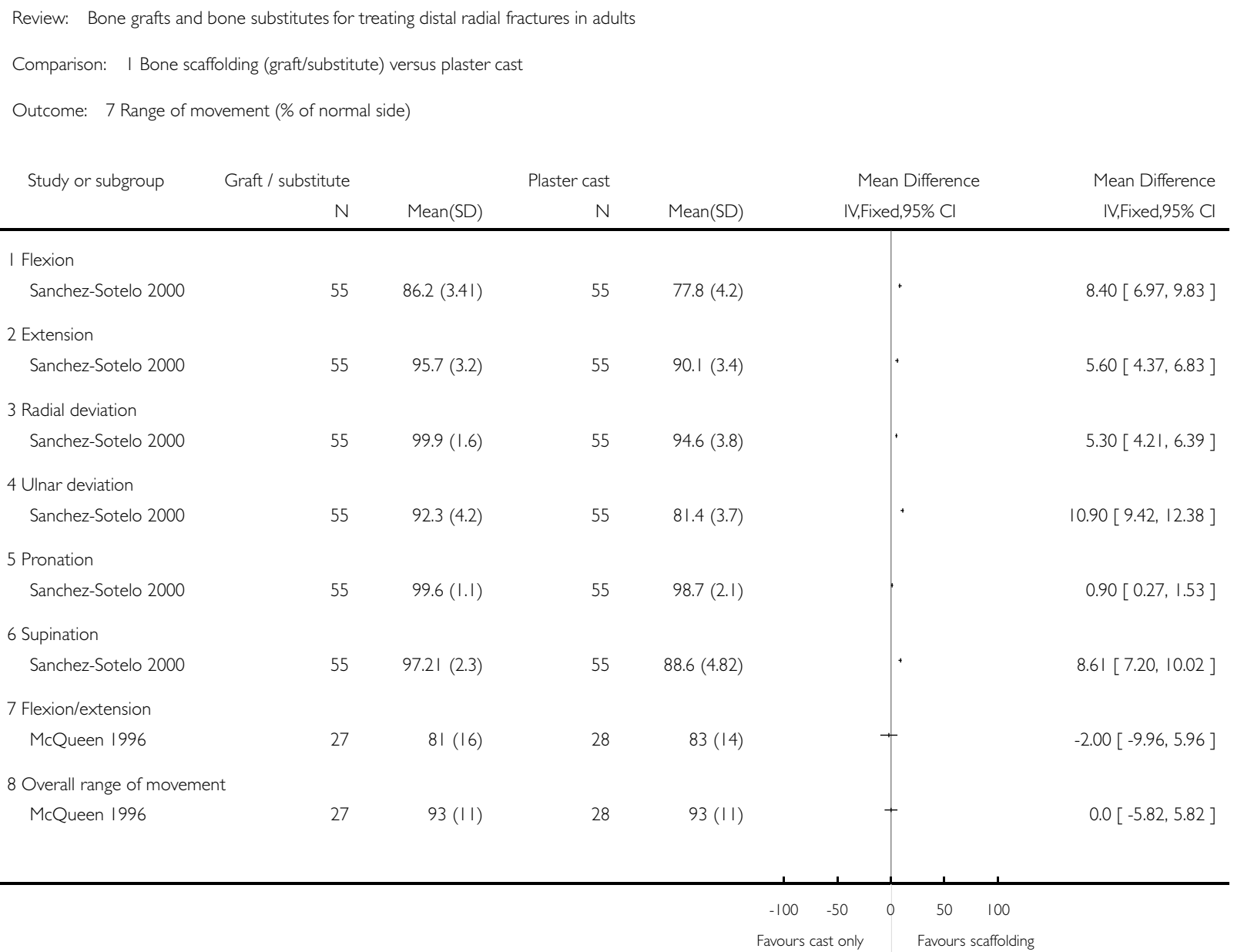




\section{Analysis I.8. Comparison I Bone scaffolding (graft/substitute) versus plaster cast, Outcome 8 Complications.}

Review: Bone grafts and bone substitutes for treating distal radial fractures in adults

Comparison: I Bone scaffolding (graft/substitute) versus plaster cast

Outcome: 8 Complications

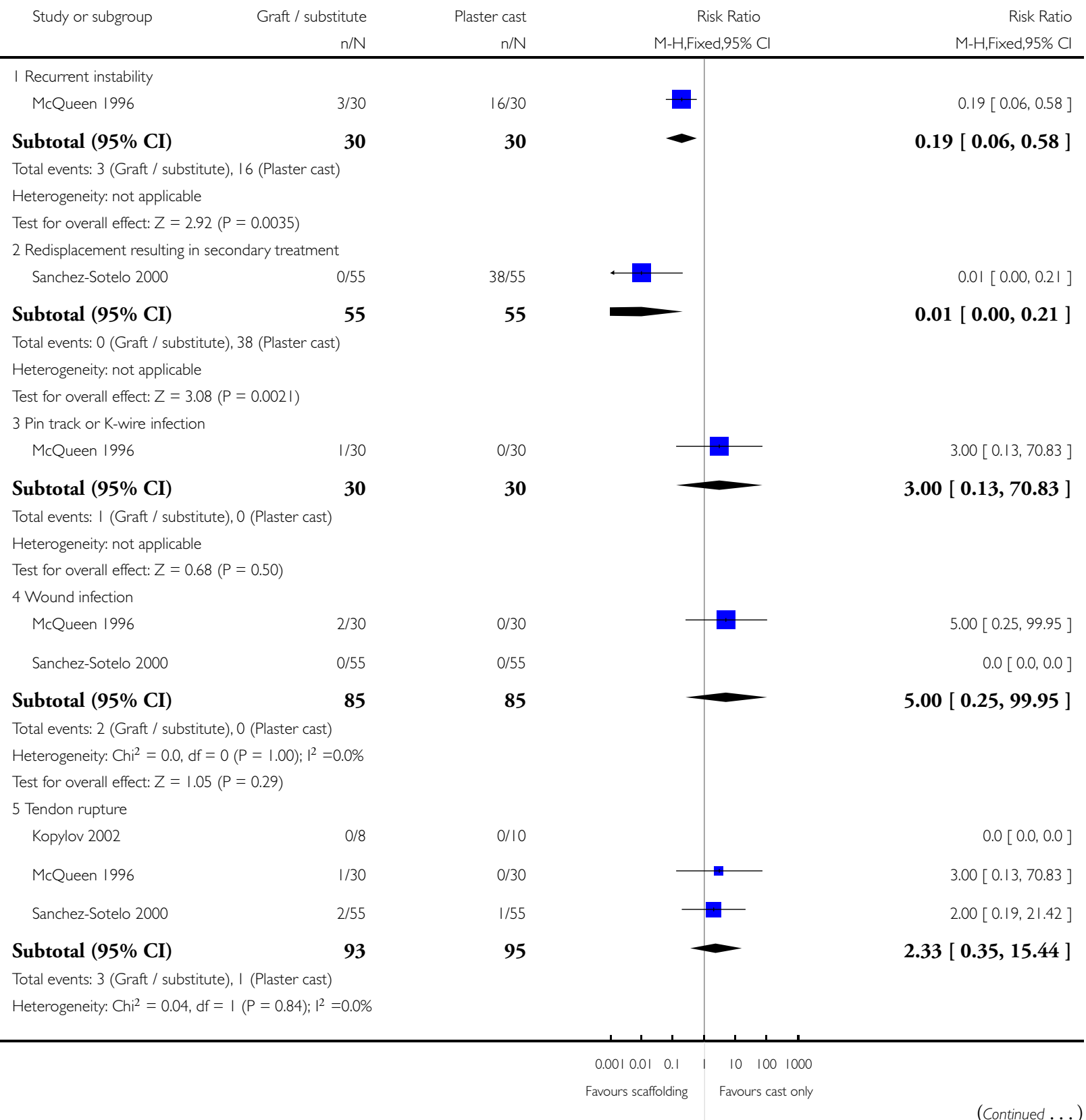




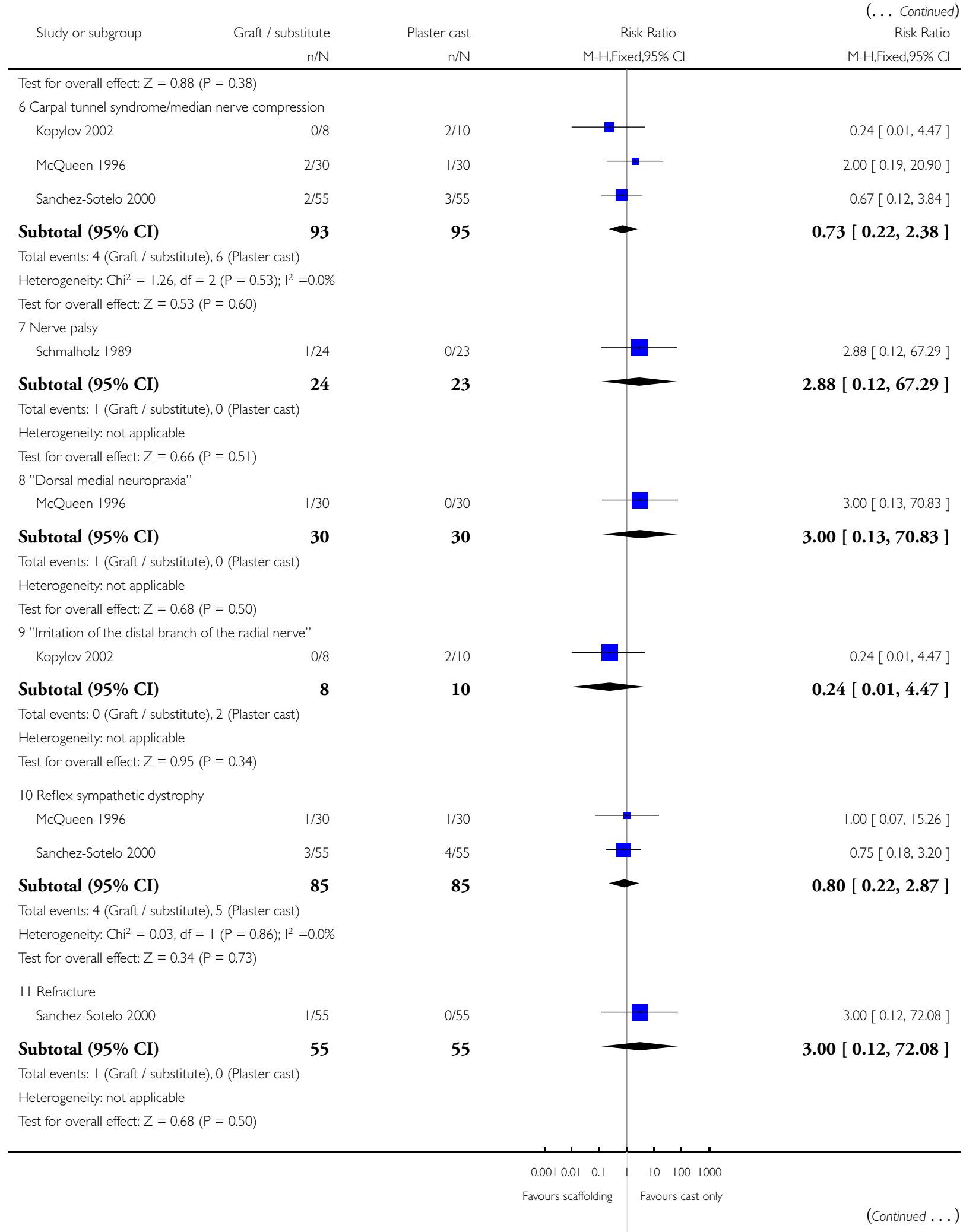




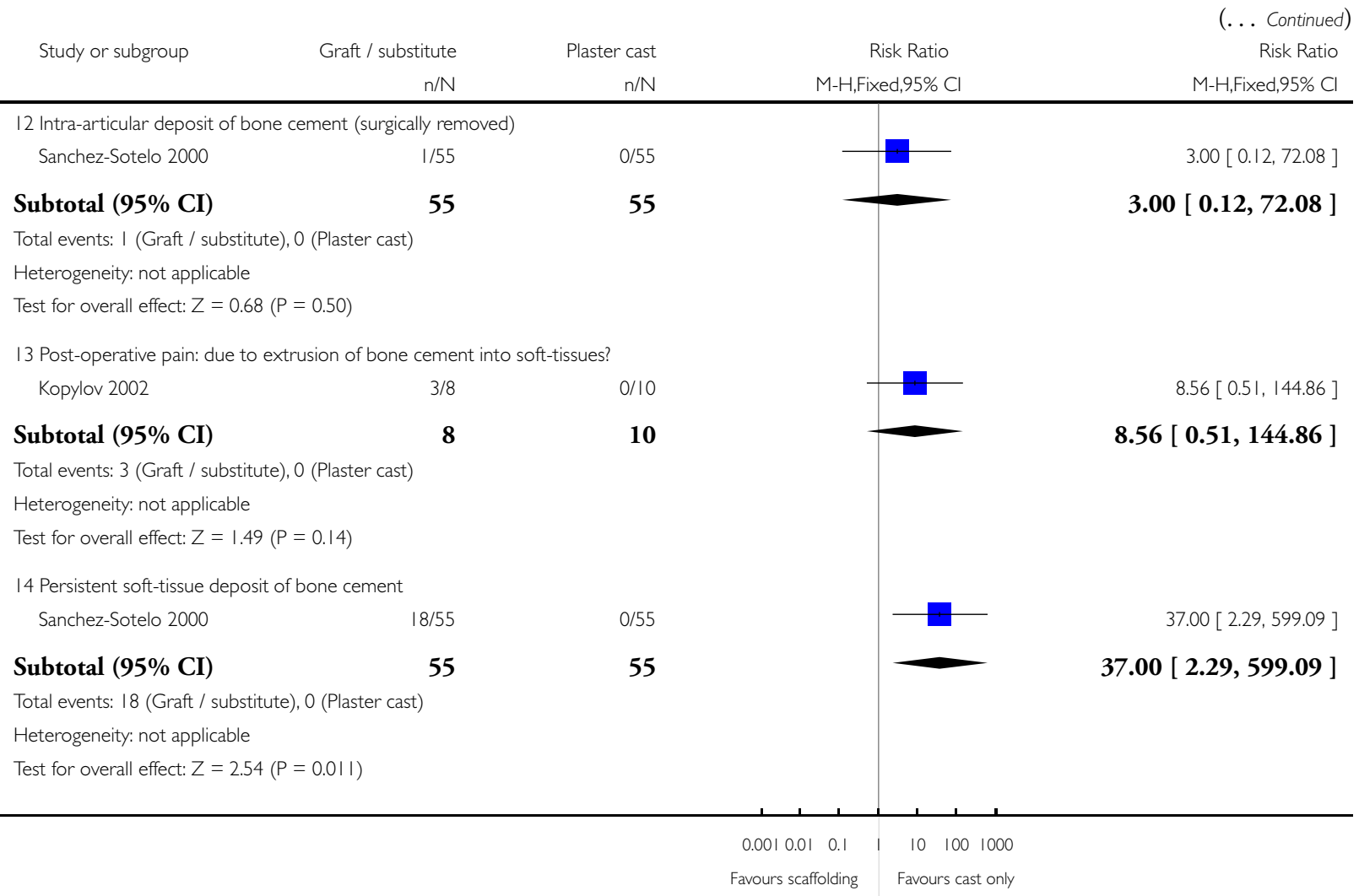

Analysis I.9. Comparison I Bone scaffolding (graft/substitute) versus plaster cast, Outcome 9 Anatomical displacement.

Review: Bone grafts and bone substitutes for treating distal radial fractures in adults

Comparison: I Bone scaffolding (graft/substitute) versus plaster cast

Outcome: 9 Anatomical displacement

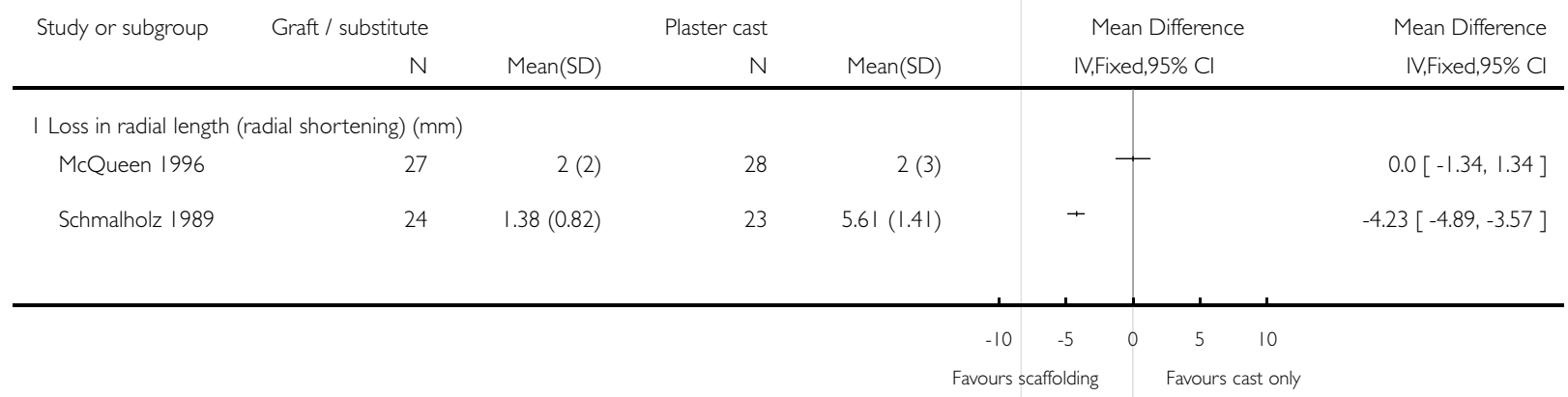


Analysis I.I0. Comparison I Bone scaffolding (graft/substitute) versus plaster cast, Outcome 10 Anatomical measurements.

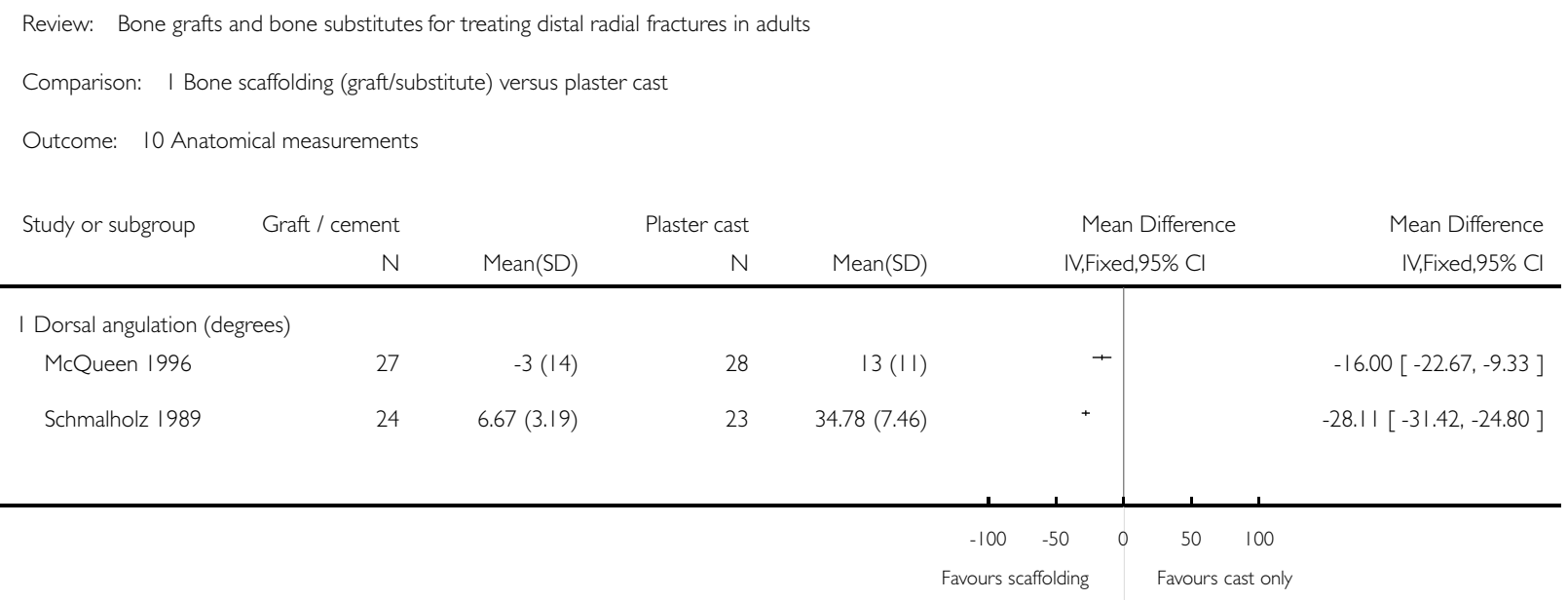

Analysis I.I I. Comparison I Bone scaffolding (graft/substitute) versus plaster cast, Outcome II Deformity (cosmetic and structural).

Review: Bone grafts and bone substitutes for treating distal radial fractures in adults

Comparison: I Bone scaffolding (graft/substitute) versus plaster cast

Outcome: II Deformity (cosmetic and structural)

\begin{tabular}{|c|c|c|c|c|c|}
\hline \multirow[t]{2}{*}{ Study or subgroup } & Graft / substitute & Plaster cast & Risk Ratio & \multirow[t]{2}{*}{ Weight } & \multirow{2}{*}{$\begin{array}{r}\text { Risk Ratio } \\
\text { M-H,Fixed,95\% Cl }\end{array}$} \\
\hline & $\mathrm{n} / \mathrm{N}$ & $\mathrm{n} / \mathrm{N}$ & M-H,Fixed,95\% Cl & & \\
\hline \multicolumn{6}{|l|}{ I Carpal collapse } \\
\hline McQueen 1996 & $11 / 30$ & $14 / 30$ & & $100.0 \%$ & $0.79[0.43,1.44]$ \\
\hline Subtotal $(95 \% \mathrm{CI})$ & 30 & 30 & $\bullet$ & $100.0 \%$ & $0.79[0.43,1.44]$ \\
\hline \multicolumn{6}{|c|}{ Total events: I I (Graft / substitute), 14 (Plaster cast) } \\
\hline \multicolumn{6}{|c|}{ Heterogeneity: not applicable } \\
\hline \multicolumn{6}{|c|}{ Test for overall effect: $Z=0.78(P=0.44)$} \\
\hline \multicolumn{6}{|c|}{2 Malunion } \\
\hline McQueen 1996 & $10 / 30$ & $20 / 30$ & + & $46.5 \%$ & $0.50[0.28,0.88]$ \\
\hline Sanchez-Sotelo 2000 & $10 / 55$ & $23 / 55$ & 量 & $53.5 \%$ & $0.43[0.23,0.83]$ \\
\hline Subtotal (95\% CI) & 85 & 85 & $\bullet$ & $100.0 \%$ & $0.47[0.30,0.71]$ \\
\hline \multicolumn{6}{|c|}{ Total events: 20 (Graft / substitute), 43 (Plaster cast) } \\
\hline \multicolumn{6}{|c|}{ Heterogeneity: $\mathrm{Chi}^{2}=0.1 \mathrm{I}, \mathrm{df}=\mathrm{I}(\mathrm{P}=0.75) ; \mathrm{I}^{2}=0.0 \%$} \\
\hline Test for overall effect: $Z=$ & $(P=0.00048)$ & & & & \\
\hline
\end{tabular}

$0.0010 .01 \quad 0.1 \quad 1 \quad 10 \quad 100 \quad 1000$

Favours scaffolding Favours cast only

(Continued ... ) 


\begin{tabular}{|c|c|c|c|c|c|}
\hline \multirow[t]{2}{*}{ Study or subgroup } & \multirow{2}{*}{$\begin{array}{r}\text { Graft / substitute } \\
n / N\end{array}$} & \multirow{2}{*}{$\begin{array}{r}\text { Plaster cast } \\
\mathrm{n} / \mathrm{N}\end{array}$} & Risk Ratio & \multirow[t]{2}{*}{ Weight } & \multirow{2}{*}{$\begin{array}{r}(\ldots \text { Continued) } \\
\text { Risk Ratio } \\
\text { M-H,Fixed,95\% Cl }\end{array}$} \\
\hline & & & M-H,Fixed,95\% Cl & & \\
\hline \multicolumn{3}{|c|}{3 Dissatisfaction with wrist appearance } & & & \\
\hline Schmalholz 1989 & $0 / 24$ & $15 / 23$ & + & $100.0 \%$ & $0.03[0.00,0.49]$ \\
\hline Subtotal $(95 \%$ CI $)$ & 24 & 23 & & $100.0 \%$ & $0.03[0.00,0.49]$ \\
\hline \multicolumn{3}{|c|}{ Total events: 0 (Graft / substitute), 15 (Plaster cast) } & & & \\
\hline \multicolumn{3}{|c|}{ Heterogeneity: not applicable } & & & \\
\hline \multicolumn{3}{|c|}{ Test for overall effect: $Z=2.47(P=0.014)$} & & & \\
\hline \multicolumn{3}{|c|}{4 Radial osteotomy performed: painful deformed wrist } & & & \\
\hline Kopylov 2002 & $0 / 8$ & $1 / 10$ & - & $100.0 \%$ & $0.41[0.02,8.84]$ \\
\hline Subtotal (95\% CI) & 8 & 10 & - & $100.0 \%$ & $0.41[0.02,8.84]$ \\
\hline \multicolumn{3}{|c|}{ Total events: 0 (Graft / substitute), I (Plaster cast) } & & & \\
\hline \multicolumn{3}{|c|}{ Heterogeneity: not applicable } & & & \\
\hline \multicolumn{3}{|c|}{ Test for overall effect: $Z=0.57(P=0.57)$} & & & \\
\hline & & & $1 \quad 10 \quad 100$ & & \\
\hline & & & Favours ca & & \\
\hline
\end{tabular}

Analysis 2.I. Comparison 2 Bone substitute versus control (plaster or external fixation), Outcome I Unsuccessful functional outcome.

Review: Bone grafts and bone substitutes for treating distal radial fractures in adults

Comparison: 2 Bone substitute versus control (plaster or external fixation)

Outcome: I Unsuccessful functional outcome

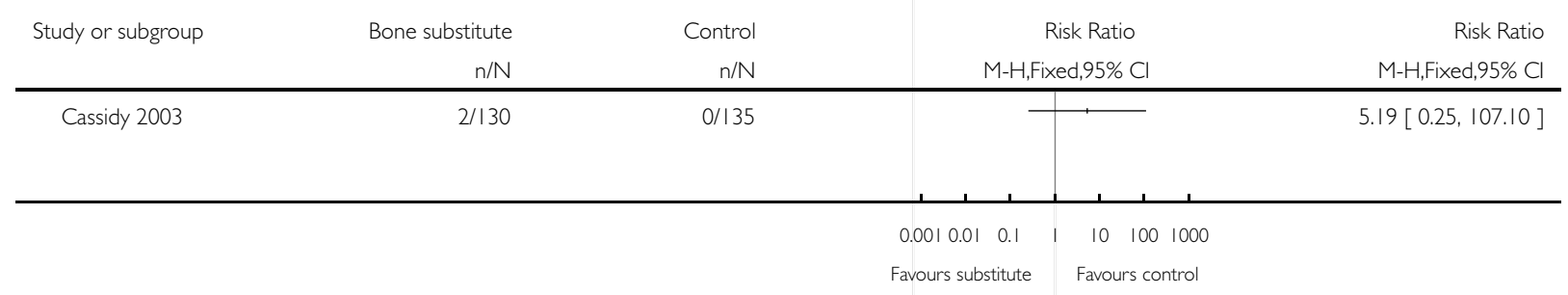


Analysis 2.2. Comparison 2 Bone substitute versus control (plaster or external fixation), Outcome 2 Grip strength (\% or normal side).

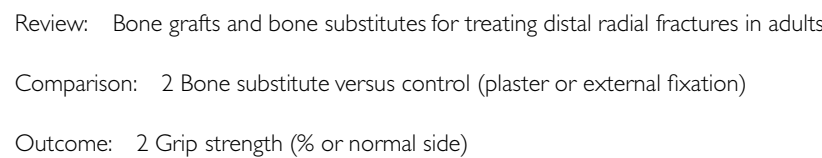

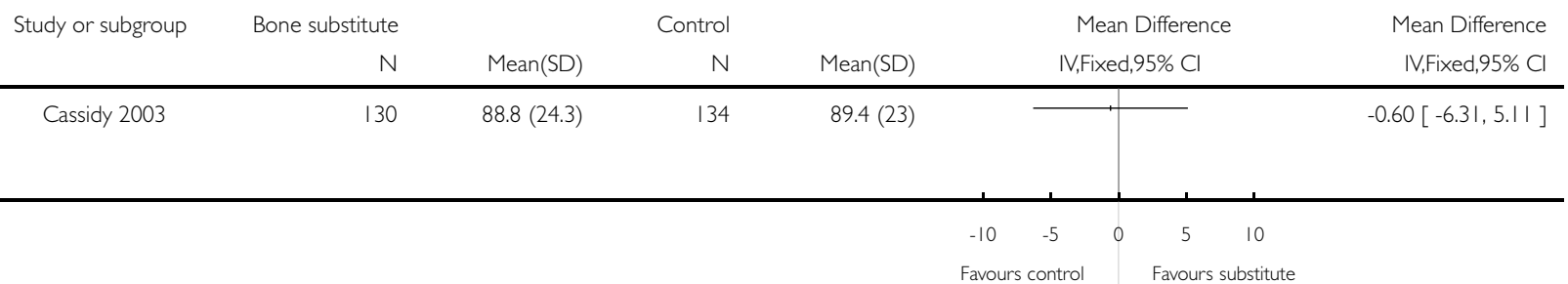

Analysis 2.3. Comparison 2 Bone substitute versus control (plaster or external fixation), Outcome 3 Pain.

Review: Bone grafts and bone substitutes for treating distal radial fractures in adults

Comparison: 2 Bone substitute versus control (plaster or external fixation)

Outcome: 3 Pain

\begin{tabular}{|c|c|c|c|c|}
\hline Study or subgroup & Bone substitute & Control & Risk Ratio & Risk Ratio \\
\hline & $\mathrm{n} / \mathrm{N}$ & $\mathrm{n} / \mathrm{N}$ & M-H,Fixed,95\% Cl & M-H,Fixed,95\% Cl \\
\hline Cassidy 2003 & $4 / 161$ & $10 / 162$ & $\cdots$ & $0.40[0.13,1.26]$ \\
\hline
\end{tabular}

$\begin{array}{lllllll}0.1 & 0.2 & 0.5 & 1 & 2 & 5 & 10\end{array}$

Favours substitute Favours control 
Analysis 2.4. Comparison 2 Bone substitute versus control (plaster or external fixation), Outcome 4 Range of movement (\% of normal side).

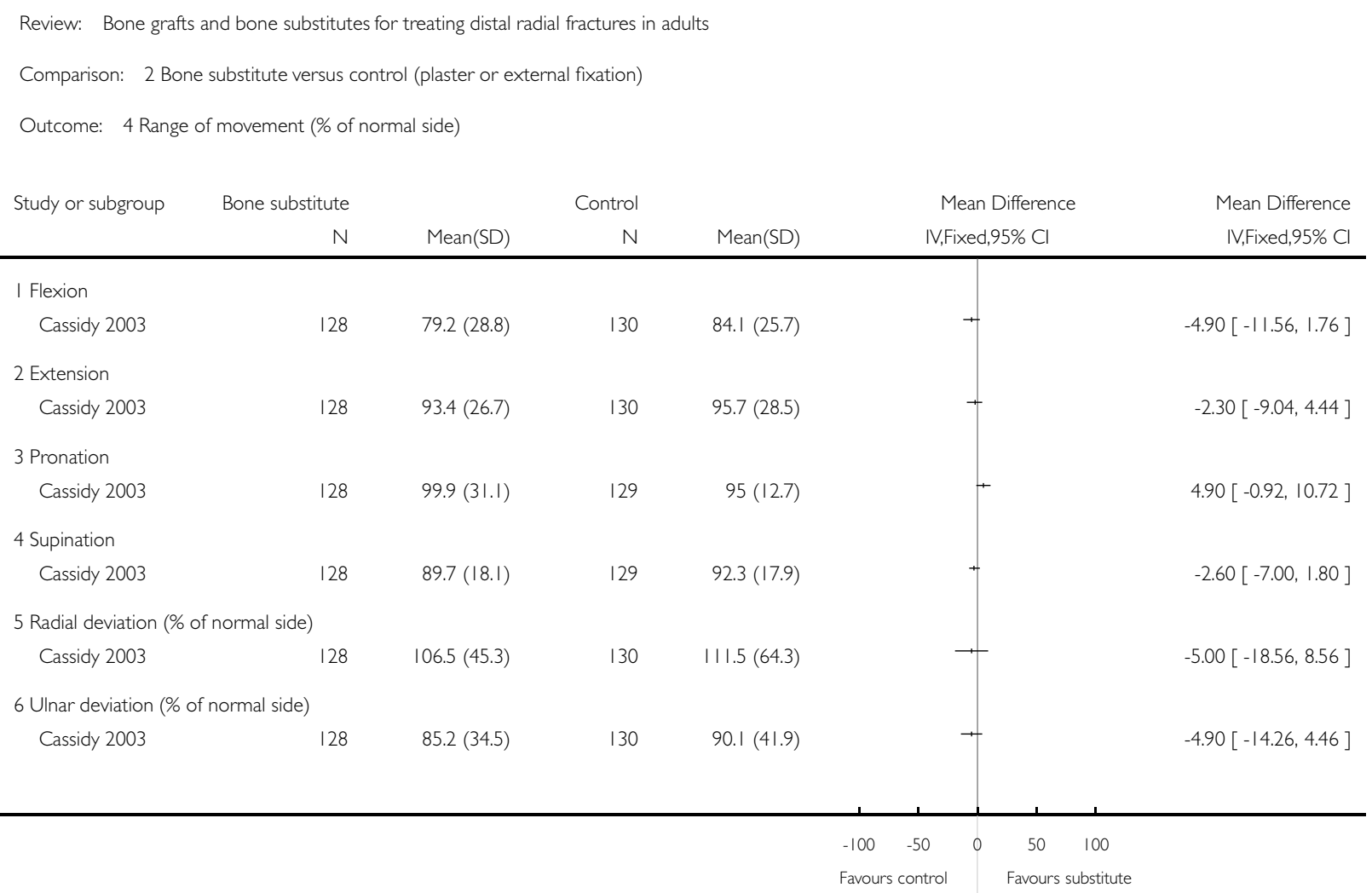


Analysis 2.5. Comparison 2 Bone substitute versus control (plaster or external fixation), Outcome 5 I0\% or more deficit in range of motion compared with normal side.

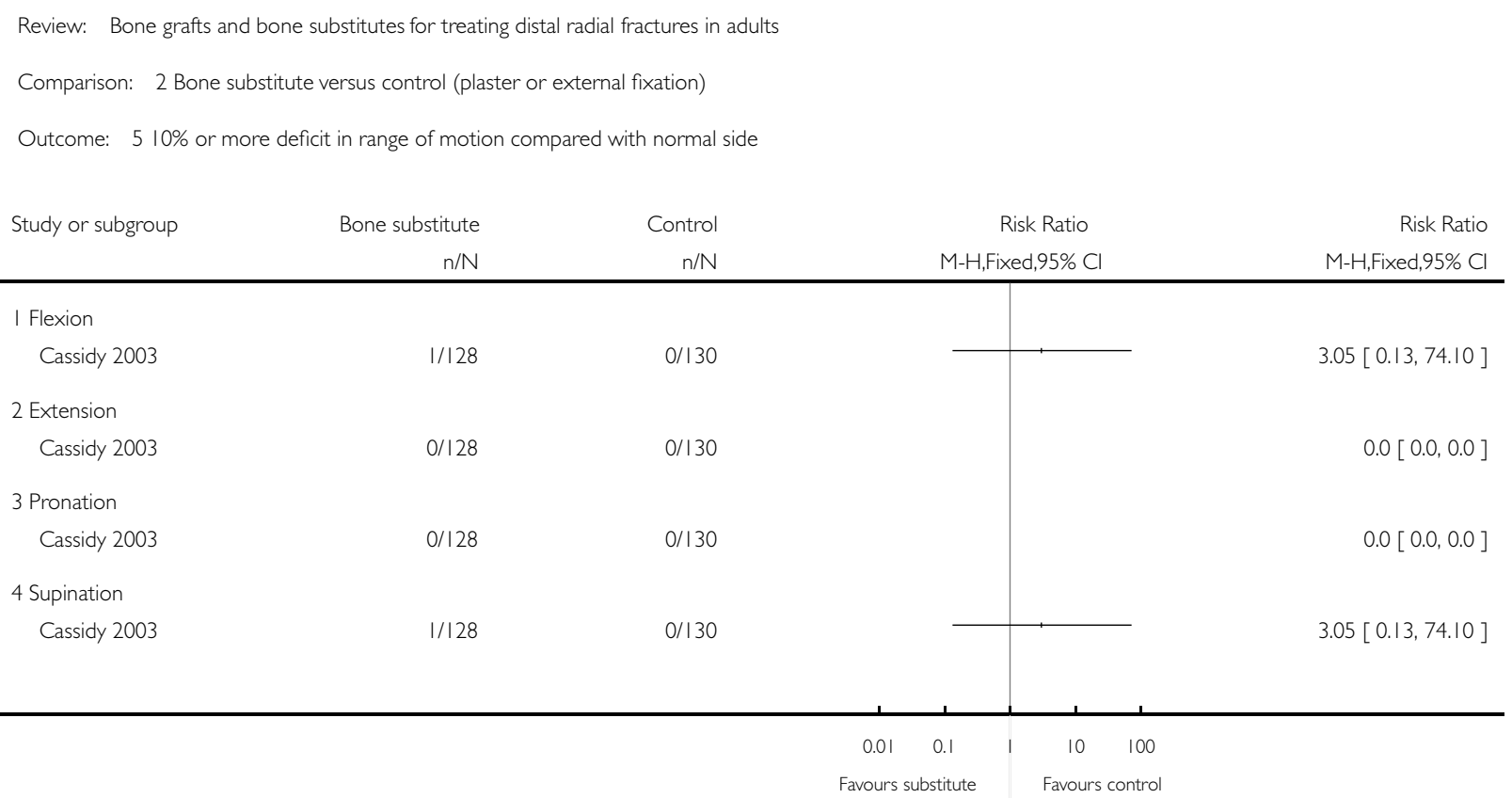


Analysis 2.6. Comparison 2 Bone substitute versus control (plaster or external fixation), Outcome 6 Complications.

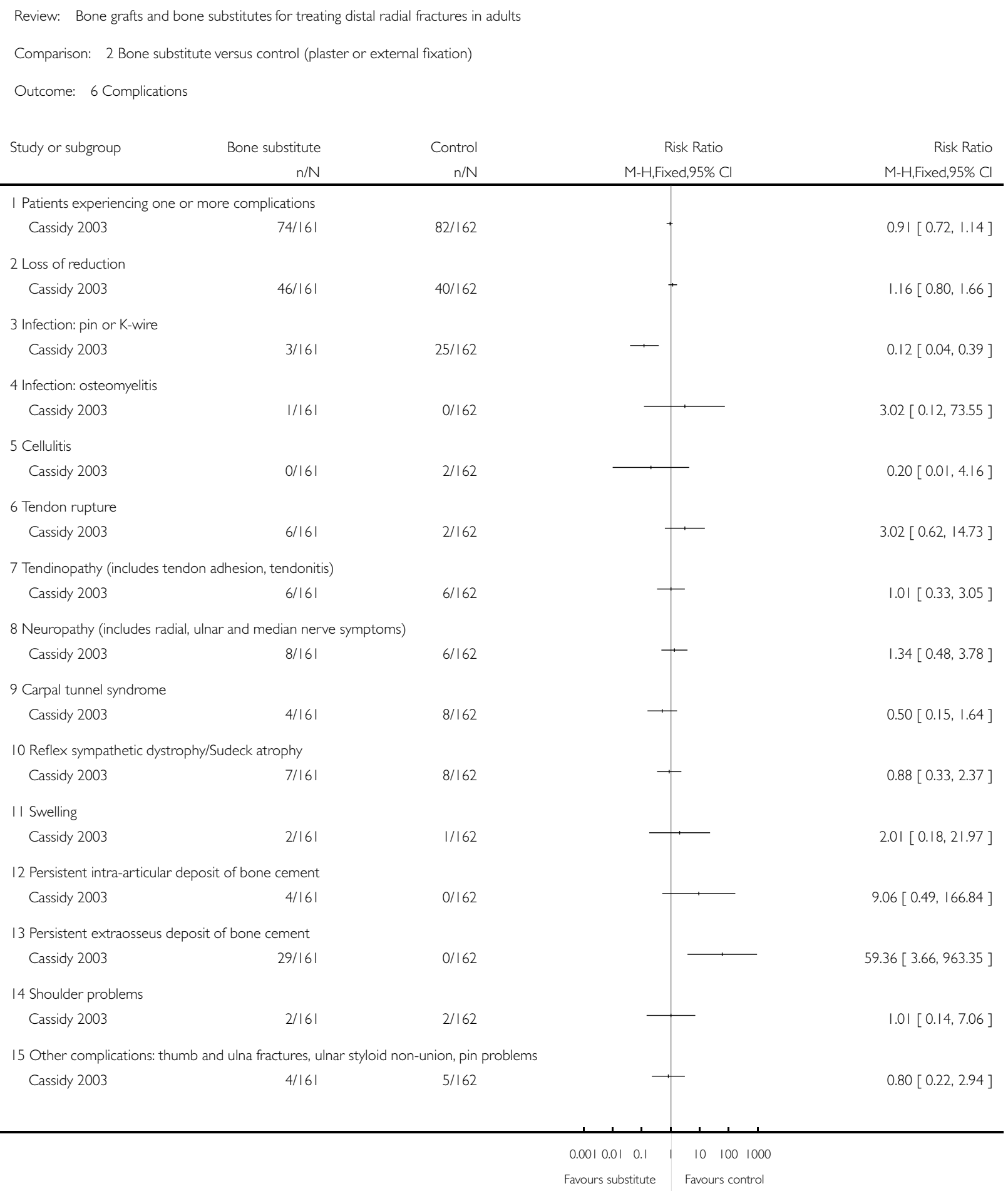


Analysis 2.7. Comparison 2 Bone substitute versus control (plaster or external fixation), Outcome 7 Anatomical measurements.

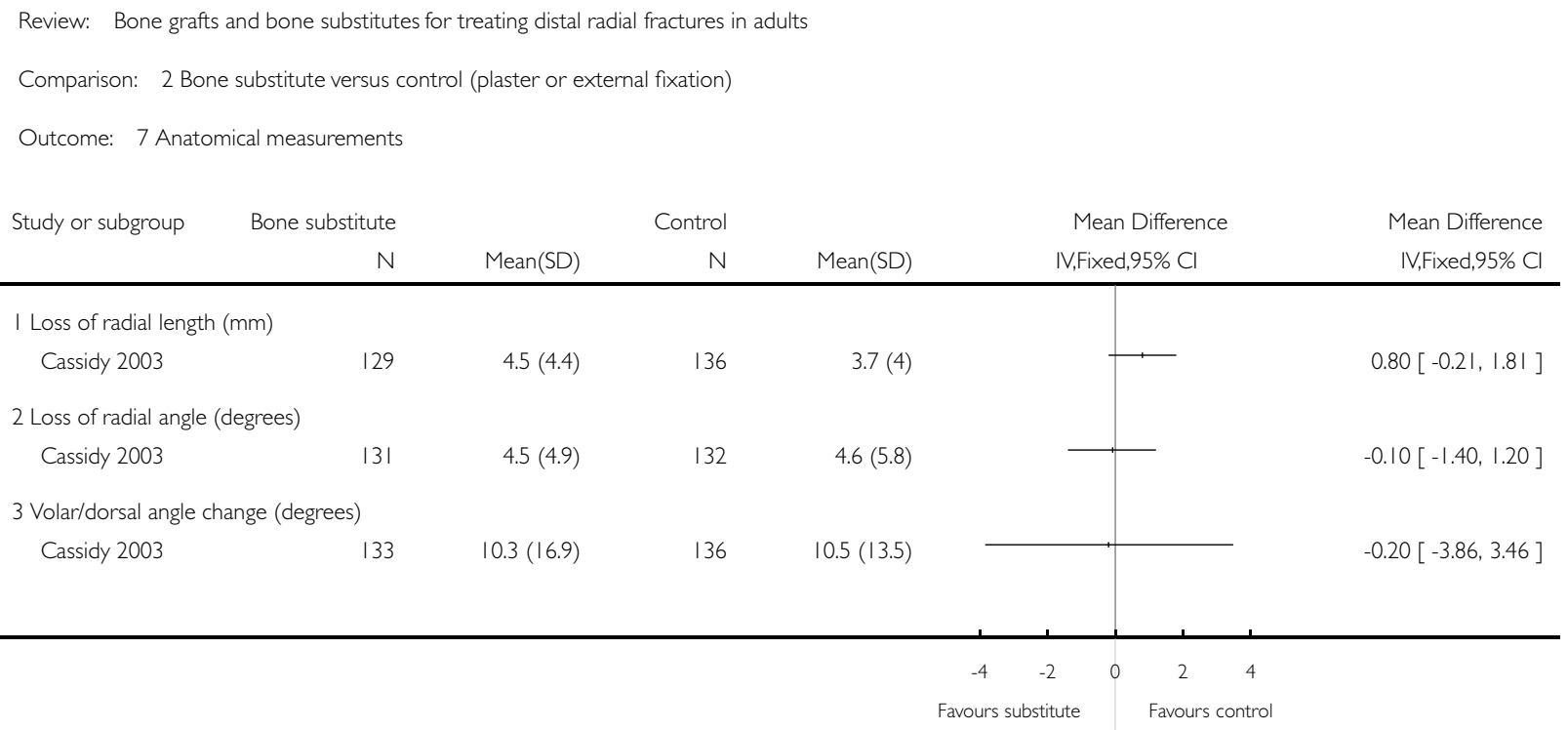

Analysis 2.8. Comparison 2 Bone substitute versus control (plaster or external fixation), Outcome 8 Unsuccessful radiographic outcome measures.

Review: Bone grafts and bone substitutes for treating distal radial fractures in adults

Comparison: 2 Bone substitute versus control (plaster or external fixation)

Outcome: 8 Unsuccessful radiographic outcome measures

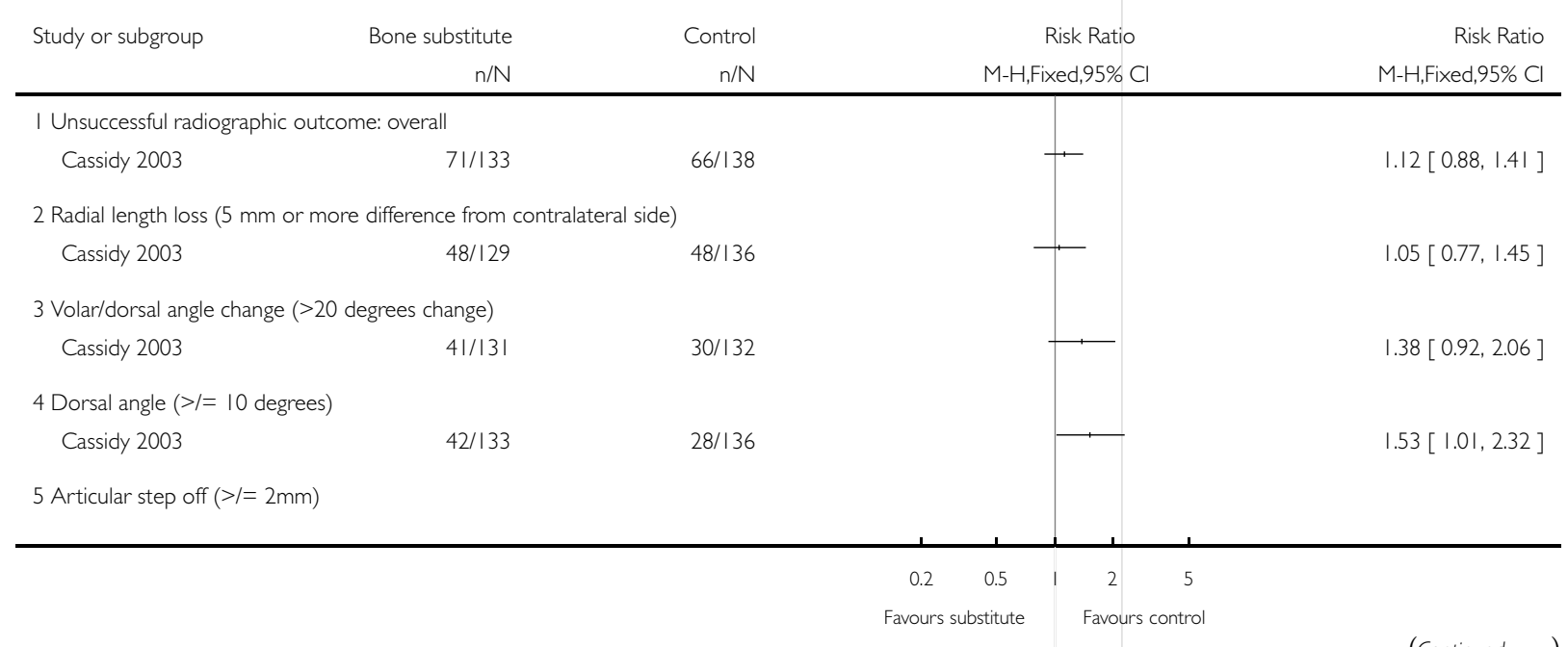

(Continued ...) 


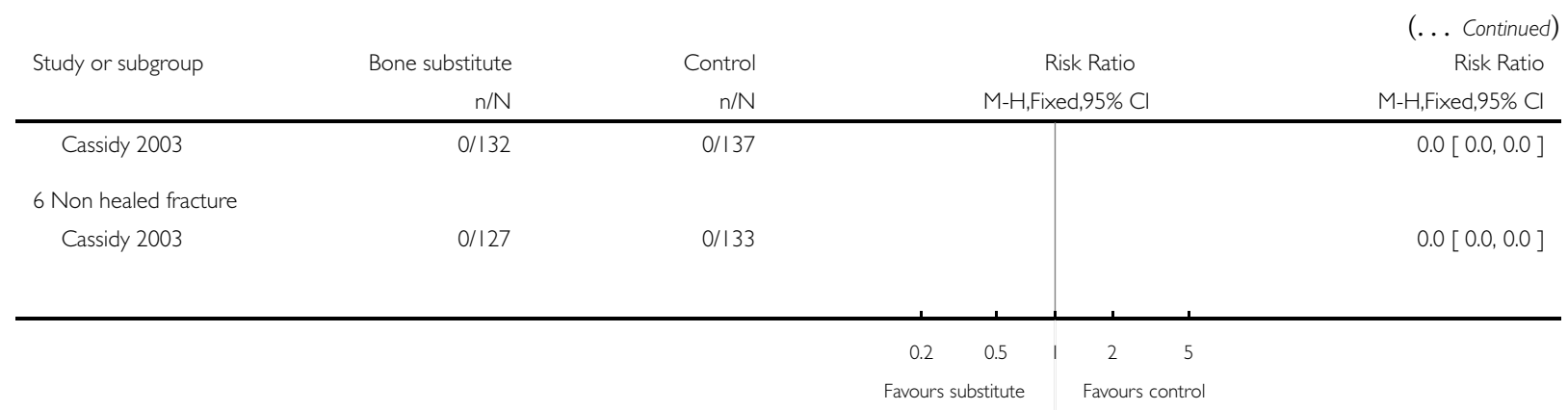

Analysis 3.I. Comparison 3 Bone graft, external fixation then plaster cast versus external fixation, Outcome I Poor function and grip strength (at I year).

Review: Bone grafts and bone substitutes for treating distal radial fractures in adults

Comparison: 3 Bone graft, external fixation then plaster cast versus external fixation

Outcome: I Poor function and grip strength (at I year)

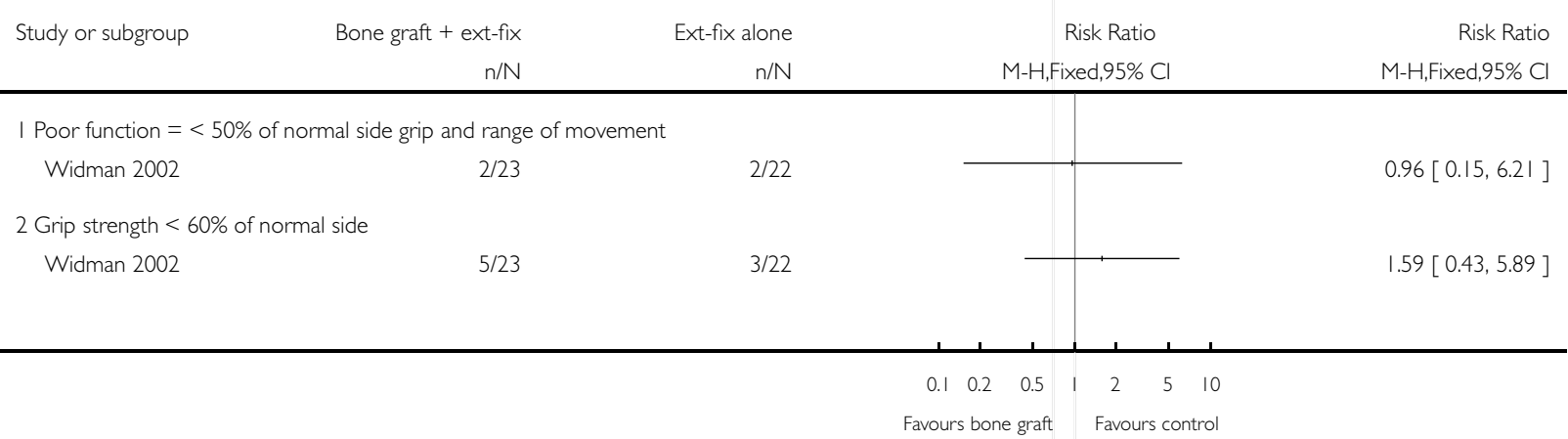


Analysis 3.2. Comparison 3 Bone graft, external fixation then plaster cast versus external fixation, Outcome 2 Mass grip strength (\% of normal side).

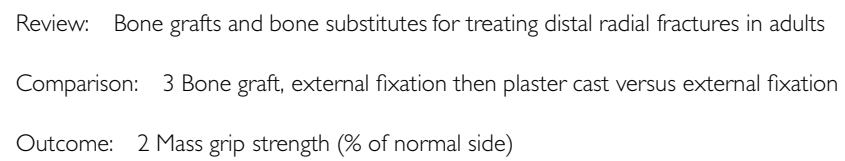

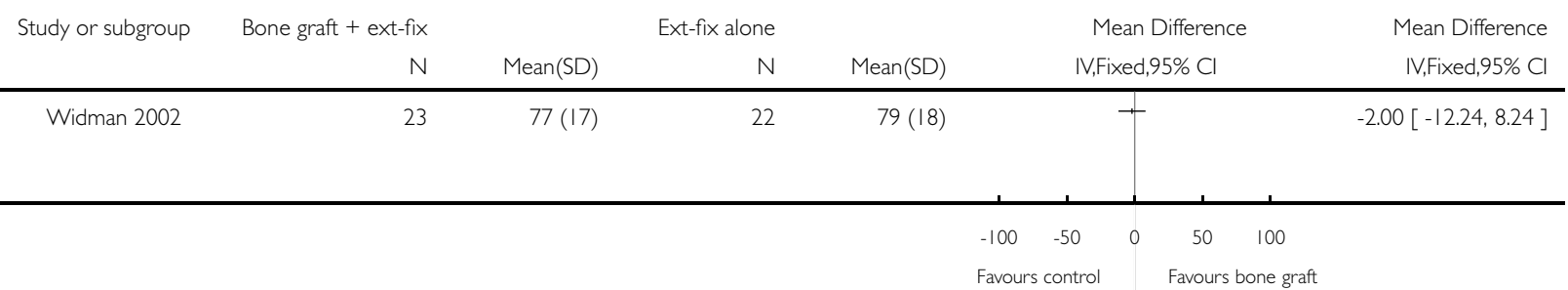

Analysis 3.3. Comparison 3 Bone graft, external fixation then plaster cast versus external fixation, Outcome 3 Range of movement (\% of normal side).

Review: Bone grafts and bone substitutes for treating distal radial fractures in adults

Comparison: 3 Bone graft, external fixation then plaster cast versus external fixation

Outcome: 3 Range of movement (\% of normal side)

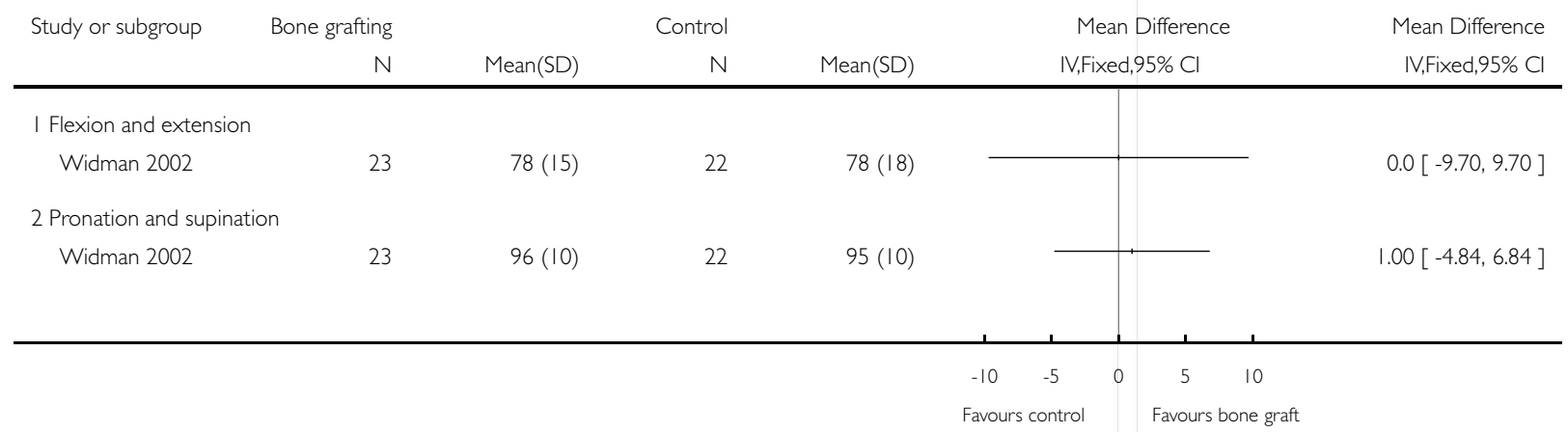


Analysis 3.4. Comparison 3 Bone graft, external fixation then plaster cast versus external fixation, Outcome 4 Complications.

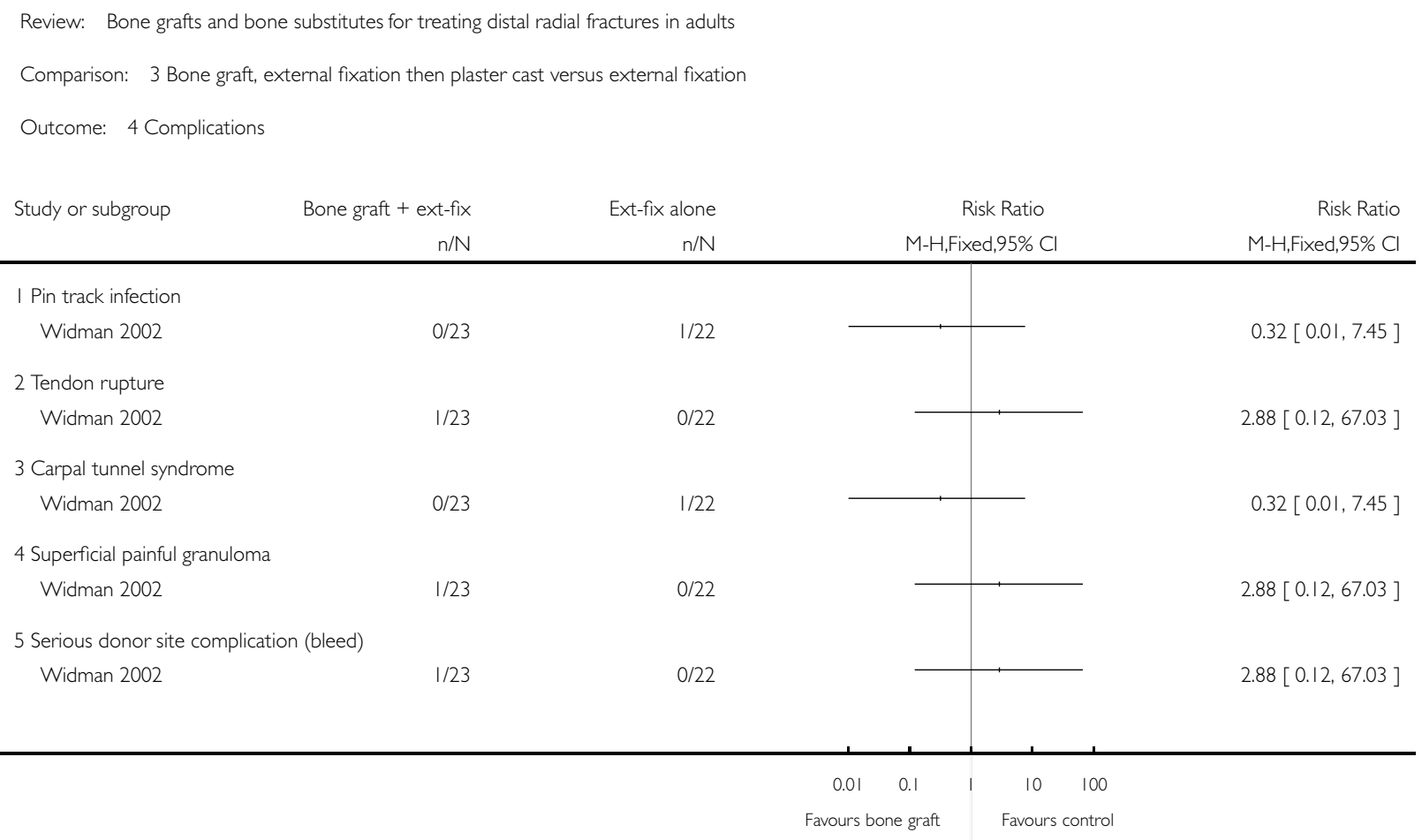

\section{Analysis 3.5. Comparison 3 Bone graft, external fixation then plaster cast versus external fixation,} Outcome 5 Anatomical measurements.

Review: Bone grafts and bone substitutes for treating distal radial fractures in adults

Comparison: 3 Bone graft, external fixation then plaster cast versus external fixation

Outcome: 5 Anatomical measurements

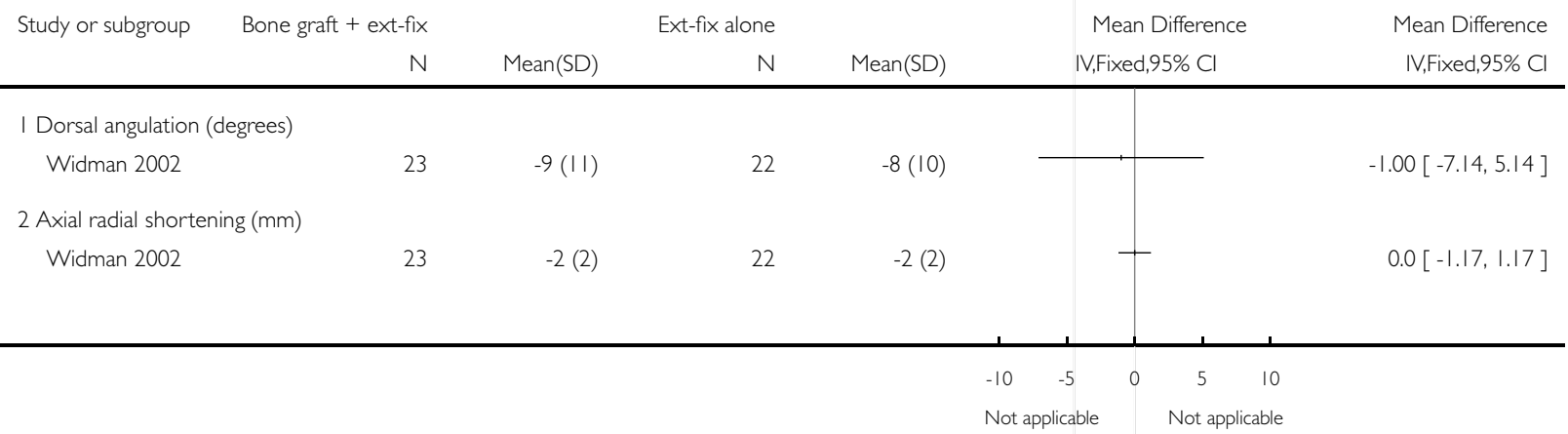


Analysis 3.6. Comparison 3 Bone graft, external fixation then plaster cast versus external fixation, Outcome 6 Deformity (severe malunion).

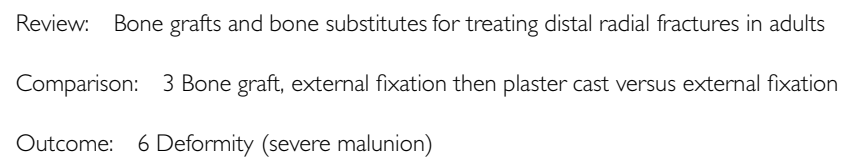

\begin{tabular}{ccccc} 
& $\mathrm{n} / \mathrm{N}$ & $\mathrm{n} / \mathrm{N}$ & $\mathrm{M}-\mathrm{H}, \mathrm{Fixed}, 95 \% \mathrm{Cl}$ & $\mathrm{M}-\mathrm{H}, \mathrm{Fixed}, 95 \% \mathrm{Cl}$ \\
\hline Widman 2002 & $2 / 23$ & $1 / 22$ & $1,1.91[0.19,19.63]$
\end{tabular}

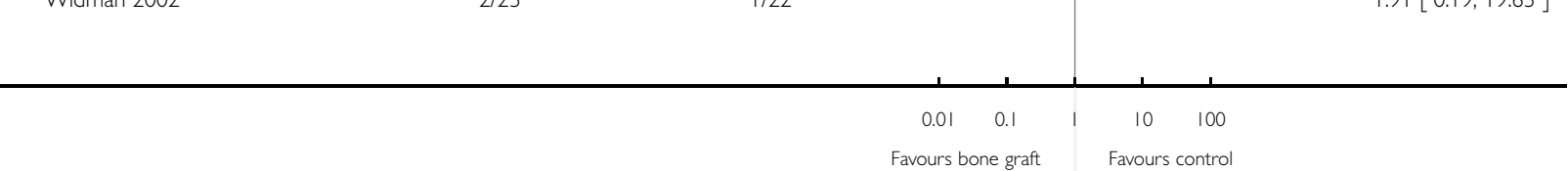

Analysis 4.I. Comparison 4 Bone substitute versus percutaneous pinning, Outcome I Palmar flexion (degrees).

Review: Bone grafts and bone substitutes for treating distal radial fractures in adults

Comparison: 4 Bone substitute versus percutaneous pinning

Outcome: I Palmar flexion (degrees)

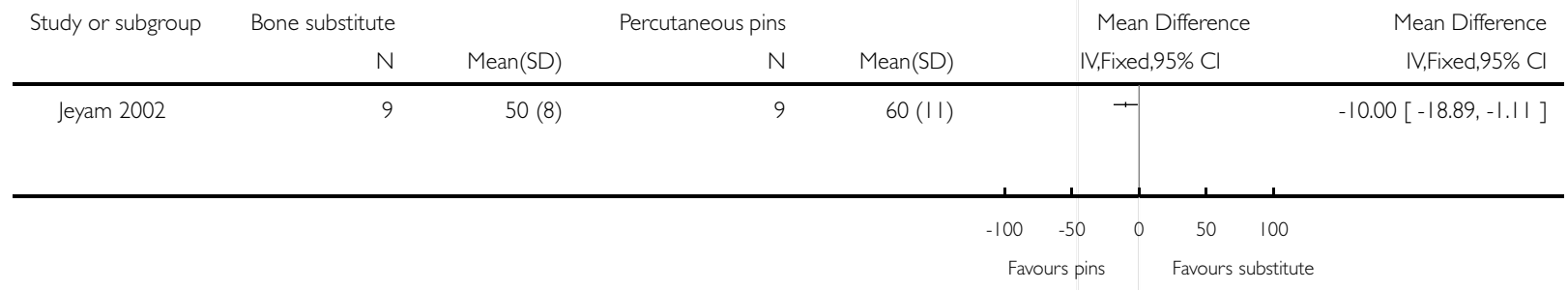


Analysis 4.2. Comparison 4 Bone substitute versus percutaneous pinning, Outcome 2 Complications. Review: Bone grafts and bone substitutes for treating distal radial fractures in adults

Comparison: 4 Bone substitute versus percutaneous pinning

Outcome: 2 Complications

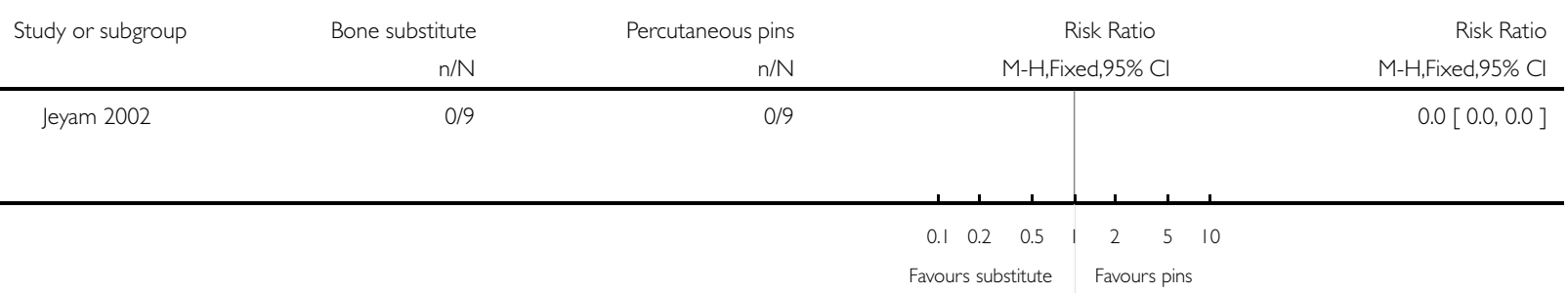

Analysis 5.I. Comparison 5 Bone scaffolding (graft/substitute) versus external fixation, Outcome I Functional gradings.

Review: Bone grafts and bone substitutes for treating distal radial fractures in adults

Comparison: 5 Bone scaffolding (graft/substitute) versus external fixation

Outcome: I Functional gradings

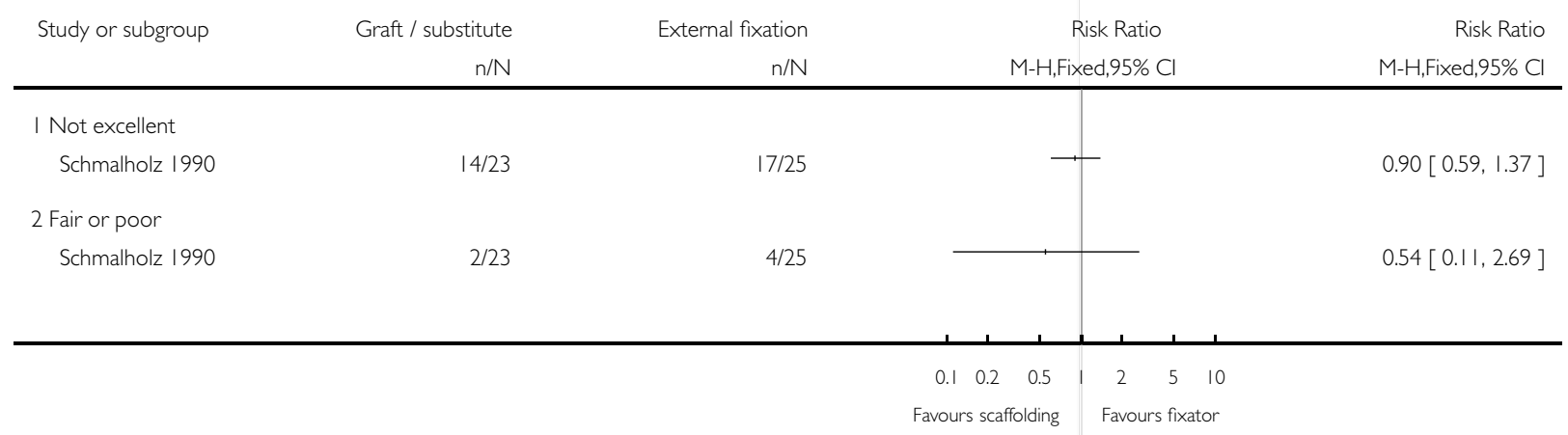


Analysis 5.2. Comparison 5 Bone scaffolding (graft/substitute) versus external fixation, Outcome 2 Non recovery of full grip strength.

Review: Bone grafts and bone substitutes for treating distal radial fractures in adults

Comparison: 5 Bone scaffolding (graft/substitute) versus external fixation

Outcome: 2 Non recovery of full grip strength

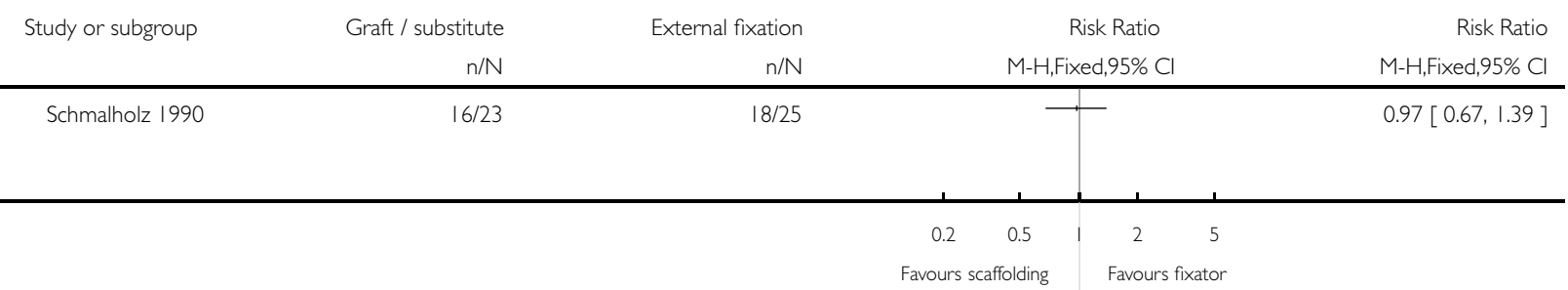

Analysis 5.3. Comparison 5 Bone scaffolding (graft/substitute) versus external fixation, Outcome 3 Mass grip strength (\% of normal side).

Review: Bone grafts and bone substitutes for treating distal radial fractures in adults

Comparison: 5 Bone scaffolding (graft/substitute) versus external fixation

Outcome: 3 Mass grip strength (\% of normal side)

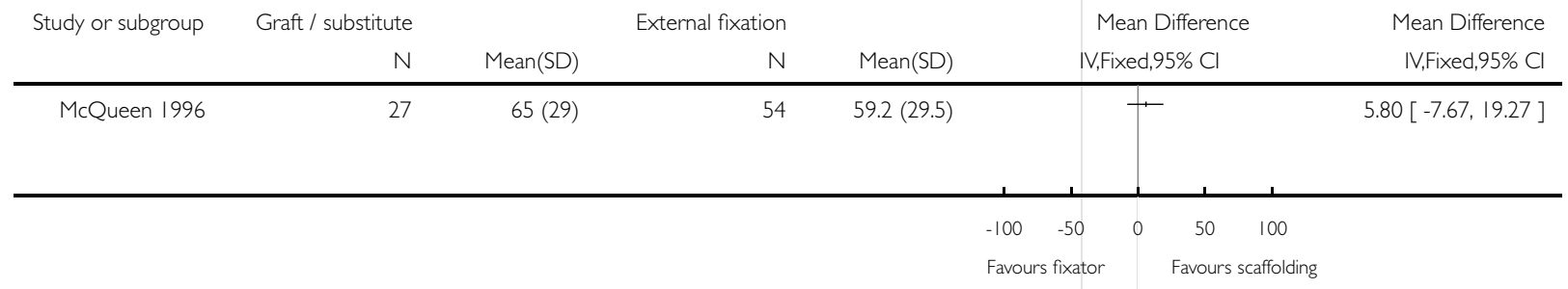


Analysis 5.4. Comparison 5 Bone scaffolding (graft/substitute) versus external fixation, Outcome 4 Persistent pain (during carrying or lifting).

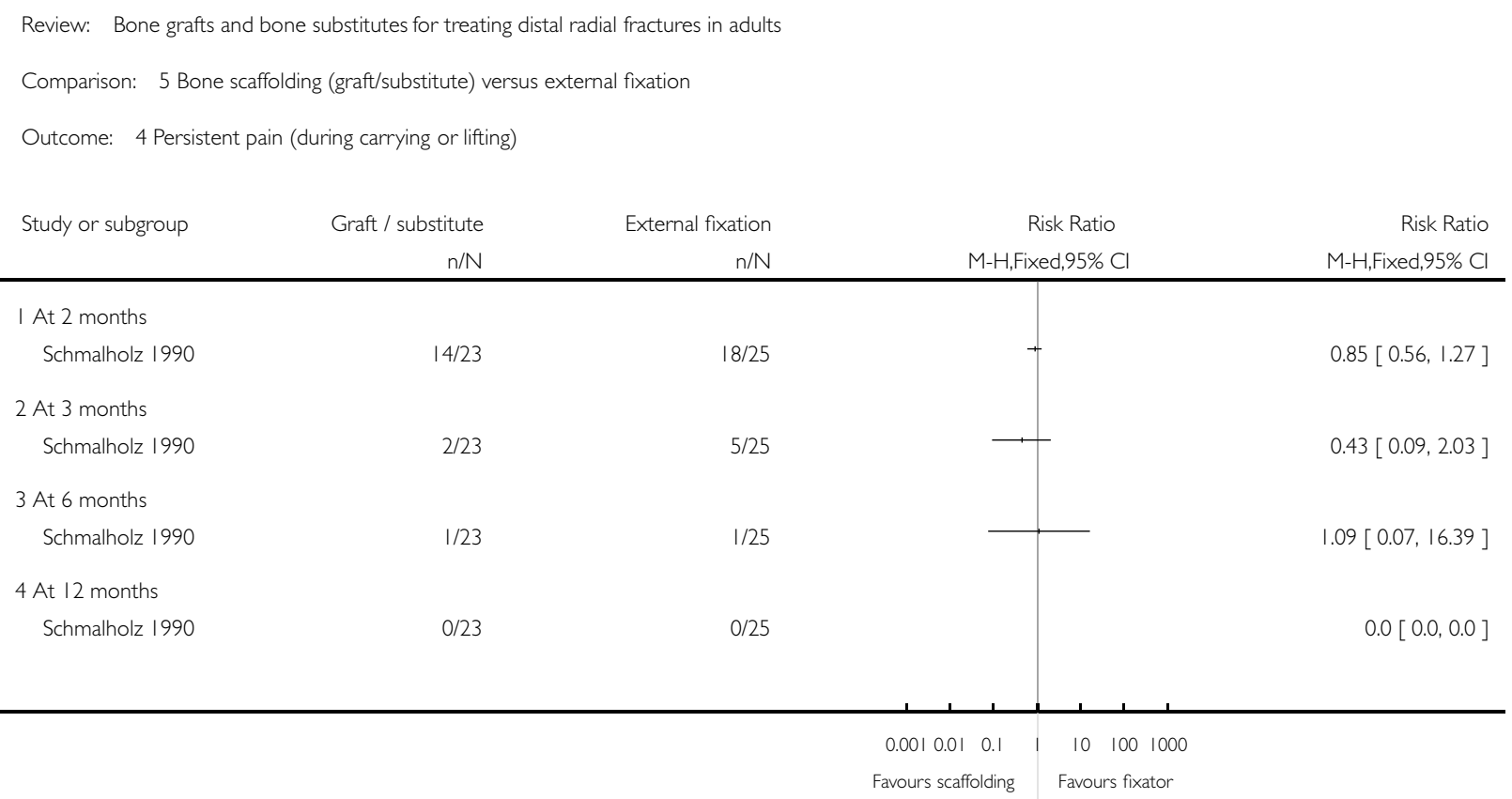

Analysis 5.5. Comparison 5 Bone scaffolding (graft/substitute) versus external fixation, Outcome 5 Nonrecovery of full range of movement.

Review: Bone grafts and bone substitutes for treating distal radial fractures in adults

Comparison: 5 Bone scaffolding (graft/substitute) versus external fixation

Outcome: 5 Non-recovery of full range of movement

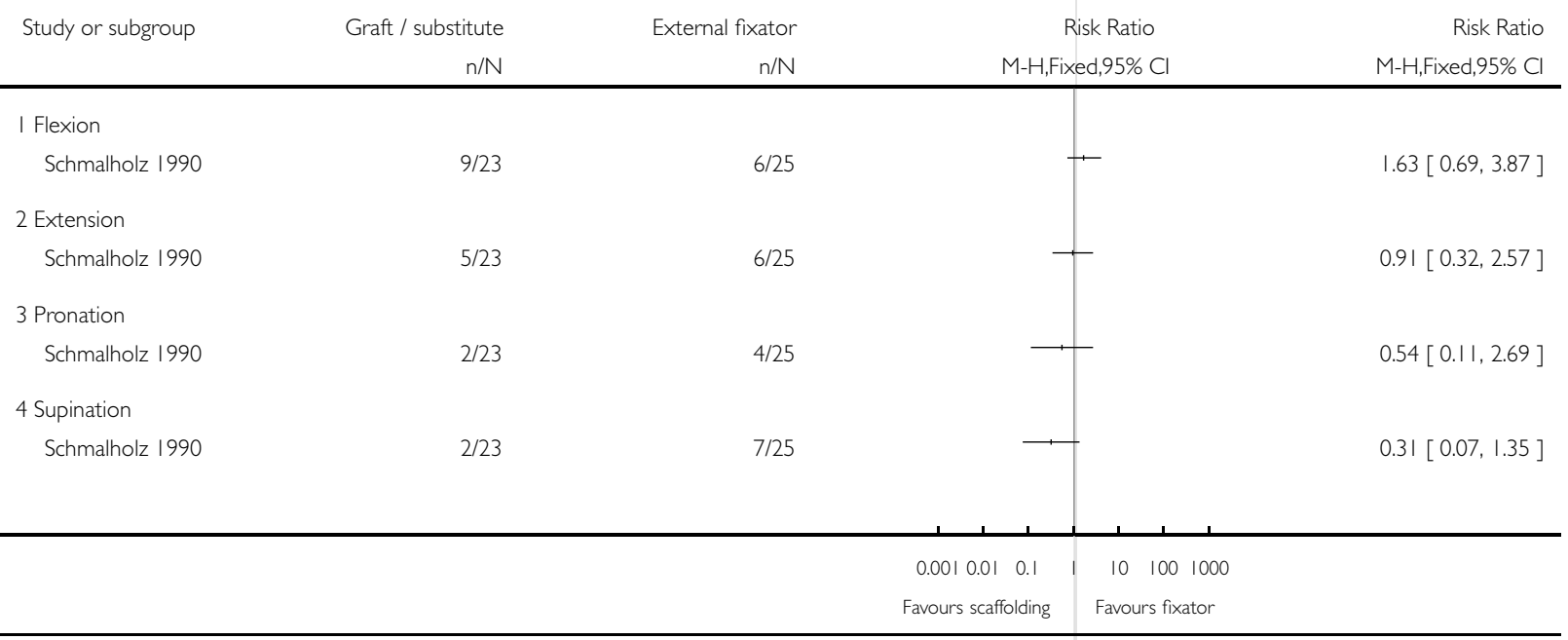


Analysis 5.6. Comparison 5 Bone scaffolding (graft/substitute) versus external fixation, Outcome 6 Range of movement (\% of normal side).

Review: Bone grafts and bone substitutes for treating distal radial fractures in adults

Comparison: 5 Bone scaffolding (graft/substitute) versus external fixation

Outcome: 6 Range of movement (\% of normal side)

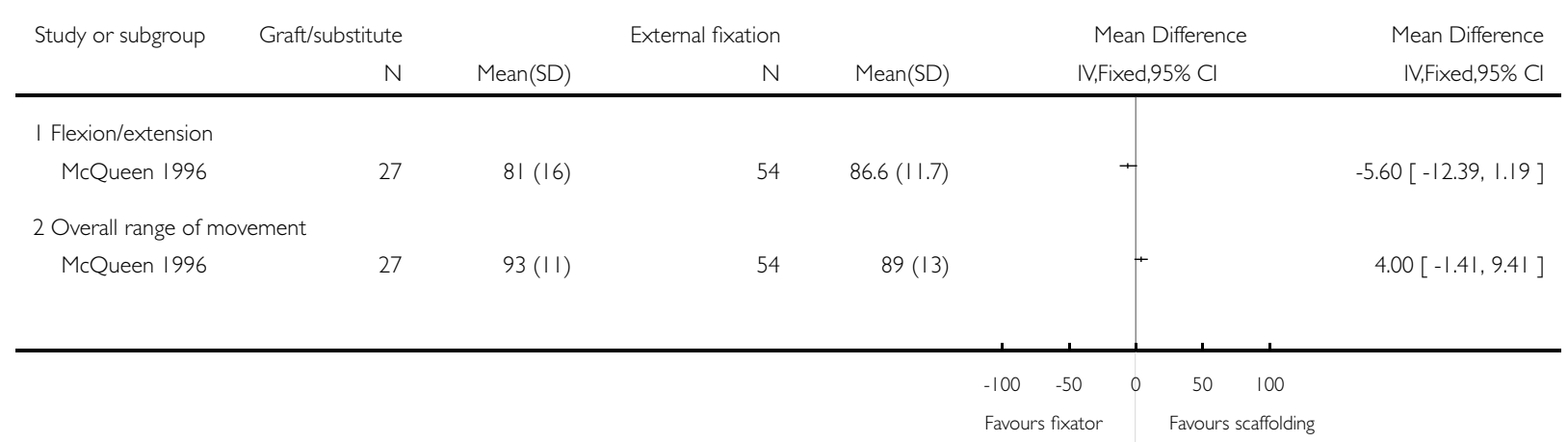




\section{Analysis 5.7. Comparison 5 Bone scaffolding (graft/substitute) versus external fixation, Outcome 7 Complications.}

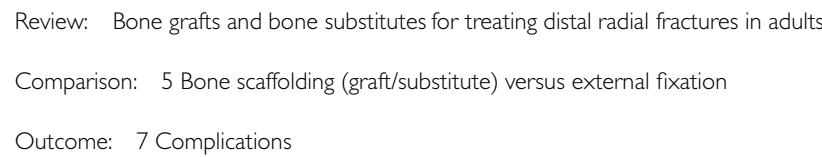

\begin{tabular}{|c|c|c|c|c|c|}
\hline \multicolumn{6}{|l|}{ I Recurrent instability } \\
\hline McQueen 1996 & $3 / 30$ & $14 / 30$ & & $100.0 \%$ & $0.21[0.07,0.67]$ \\
\hline Subtotal $(95 \% \mathrm{CI})$ & 30 & 30 & $<$ & $100.0 \%$ & $0.21[0.07,0.67]$ \\
\hline \multicolumn{6}{|c|}{ Total events: 3 (Graft / substitute), 14 (External fixation) } \\
\hline \multicolumn{6}{|c|}{ Heterogeneity: not applicable } \\
\hline \multicolumn{6}{|c|}{ Test for overall effect: $Z=2.65(P=0.0081)$} \\
\hline \multicolumn{6}{|c|}{2 Pin loosening / pin track infection requiring early fixator removal } \\
\hline McQueen 1996 & $0 / 30$ & 2/60 & 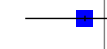 & $41.2 \%$ & $0.39[0.02,7.95]$ \\
\hline Schmalholz 1990 & $0 / 23$ & $2 / 25$ & + & $58.8 \%$ & $0.22[0.01,4.29]$ \\
\hline Subtotal $(95 \% \mathrm{CI})$ & 53 & 85 & & $100.0 \%$ & $0.29[0.04,2.35]$ \\
\hline \multicolumn{6}{|c|}{ Total events: 0 (Graft / substitute), 4 (External fixation) } \\
\hline \multicolumn{6}{|c|}{ Heterogeneity: $\mathrm{Ch}^{2}=0.08, \mathrm{df}=\mathrm{I}(\mathrm{P}=0.78) ; \mathrm{I}^{2}=0.0 \%$} \\
\hline \multicolumn{6}{|c|}{ Test for overall effect: $Z=1.16(P=0.25)$} \\
\hline \multicolumn{6}{|c|}{3 Pin track or K-wire infection } \\
\hline Kopylov 1999 & $0 / 20$ & $3 / 20$ & & $27.2 \%$ & $0.14[0.01,2.60]$ \\
\hline McQueen 1996 & 1/30 & $9 / 60$ & & $46.7 \%$ & $0.22[0.03,1.67]$ \\
\hline Schmalholz 1990 & 0/23 & $3 / 25$ & & $26.1 \%$ & $0.15[0.01,2.84]$ \\
\hline Subtotal $(95 \% \mathrm{CI})$ & 73 & 105 & & $100.0 \%$ & $0.18[0.04,0.77]$ \\
\hline \multicolumn{6}{|c|}{ Total events: I (Graft / substitute), 15 (External fixation) } \\
\hline \multicolumn{6}{|c|}{ Heterogeneity: $\mathrm{Ch}^{2}=0.08, \mathrm{df}=2(P=0.96) ; 1^{2}=0.0 \%$} \\
\hline \multicolumn{6}{|c|}{ Test for overall effect: $Z=2.32(P=0.020)$} \\
\hline \multicolumn{6}{|c|}{4 Scar adhesion to bone requiring surgical treatment } \\
\hline Schmalholz 1990 & $0 / 23$ & $1 / 25$ & & $100.0 \%$ & $0.36[0.02,8.45]$ \\
\hline Subtotal $(95 \% \mathrm{CI})$ & 23 & 25 & & $100.0 \%$ & $0.36[0.02,8.45]$ \\
\hline \multicolumn{6}{|c|}{ Total events: 0 (Graft / substitute), I (External fixation) } \\
\hline \multicolumn{6}{|c|}{ Heterogeneity: not applicable } \\
\hline \multicolumn{6}{|c|}{ Test for overall effect: $Z=0.63(P=0.53)$} \\
\hline \multicolumn{6}{|c|}{5 Skin adhesions } \\
\hline Kopylov 1999 & $0 / 20$ & $3 / 20$ & & $100.0 \%$ & $0.14[0.01,2.60]$ \\
\hline Subtotal $(95 \% \mathrm{CI})$ & 20 & 20 & & $100.0 \%$ & $0.14[0.01,2.60]$ \\
\hline \multicolumn{6}{|c|}{ Total events: 0 (Graft / substitute), 3 (External fixation) } \\
\hline Heterogeneity: not applica & & & & & \\
\hline
\end{tabular}




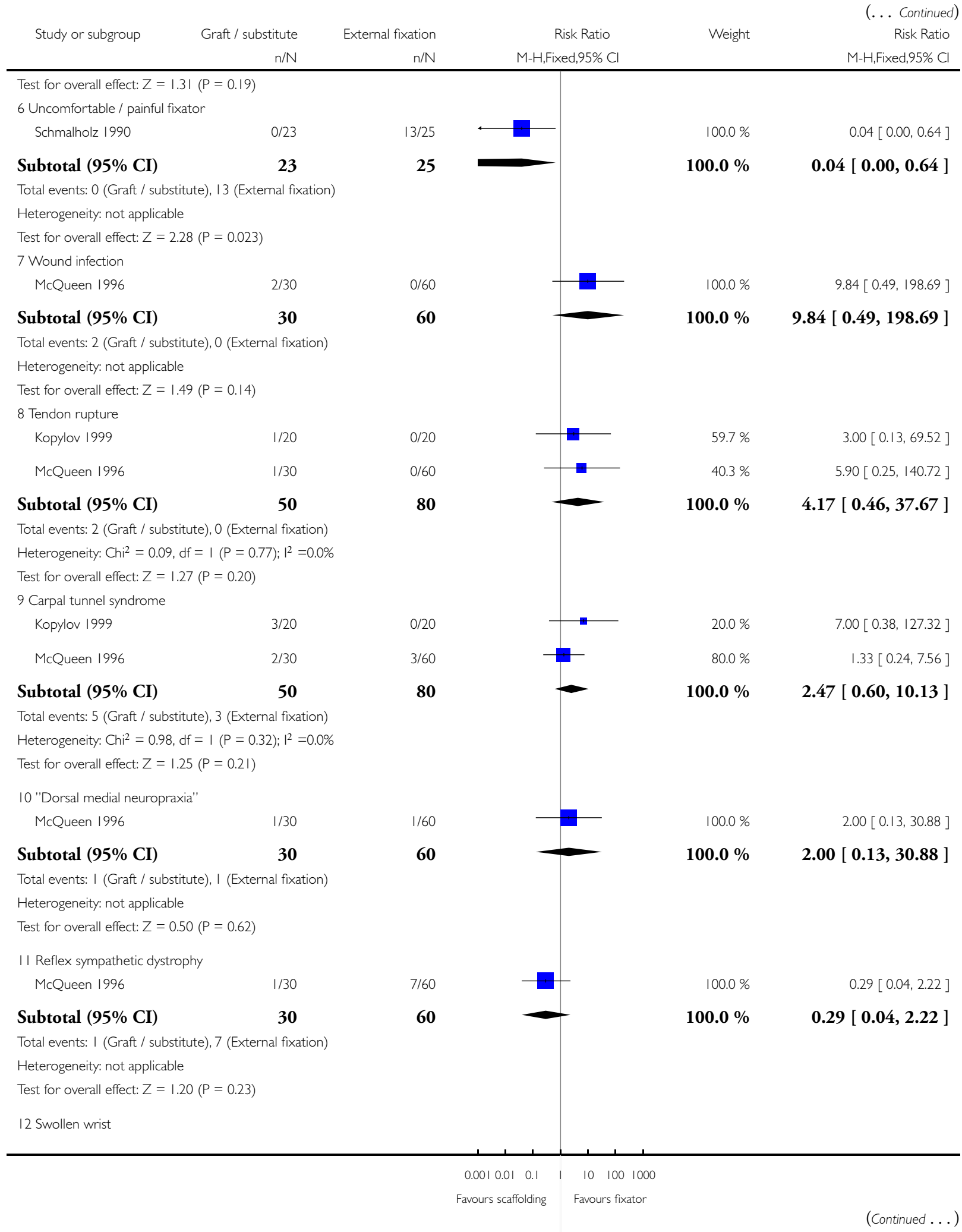




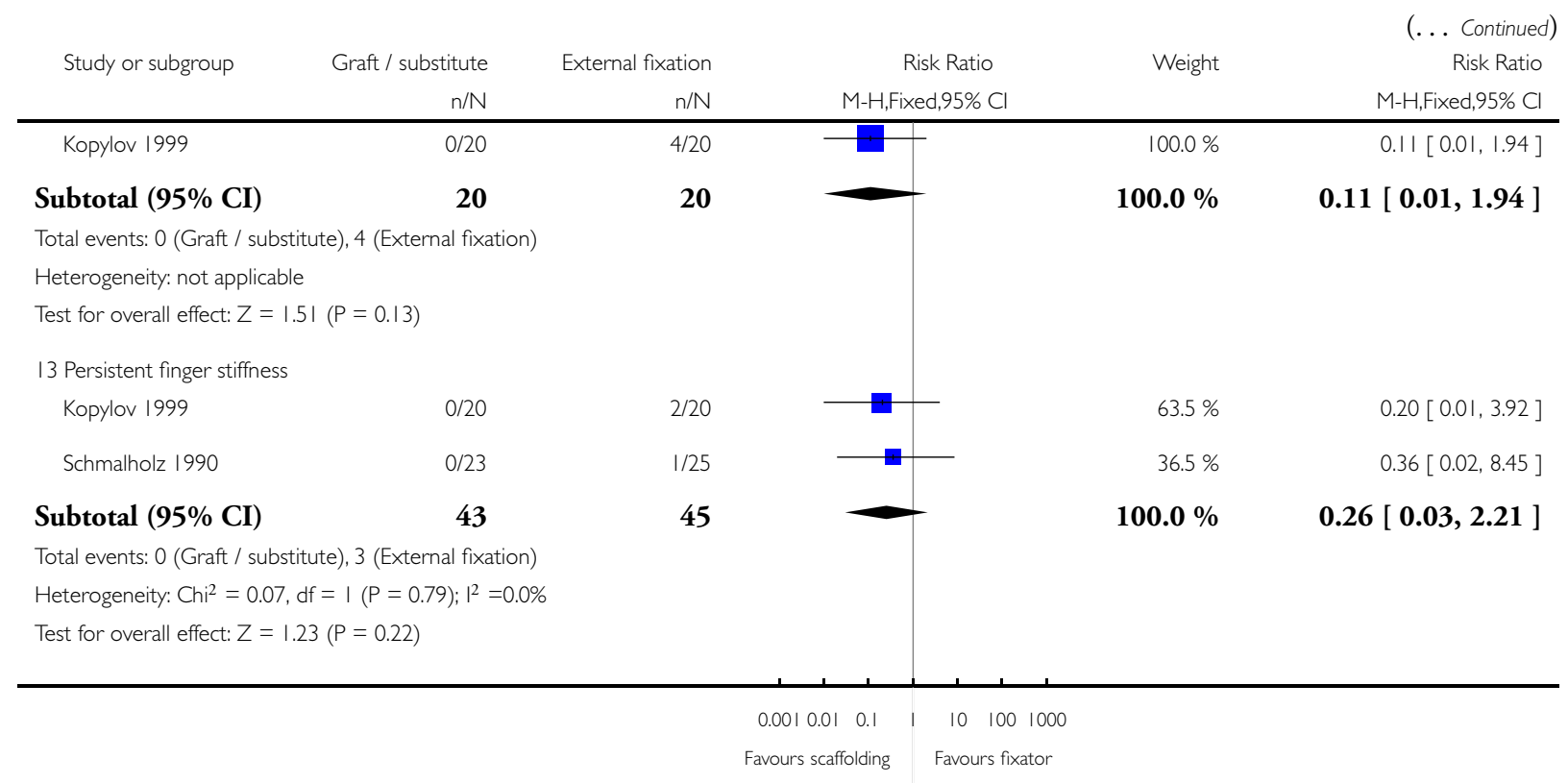

\section{Analysis 5.8. Comparison 5 Bone scaffolding (graft/substitute) versus external fixation, Outcome 8 Anatomical displacement.}

Review: Bone grafts and bone substitutes for treating distal radial fractures in adults

Comparison: 5 Bone scaffolding (graft/substitute) versus external fixation

Outcome: 8 Anatomical displacement

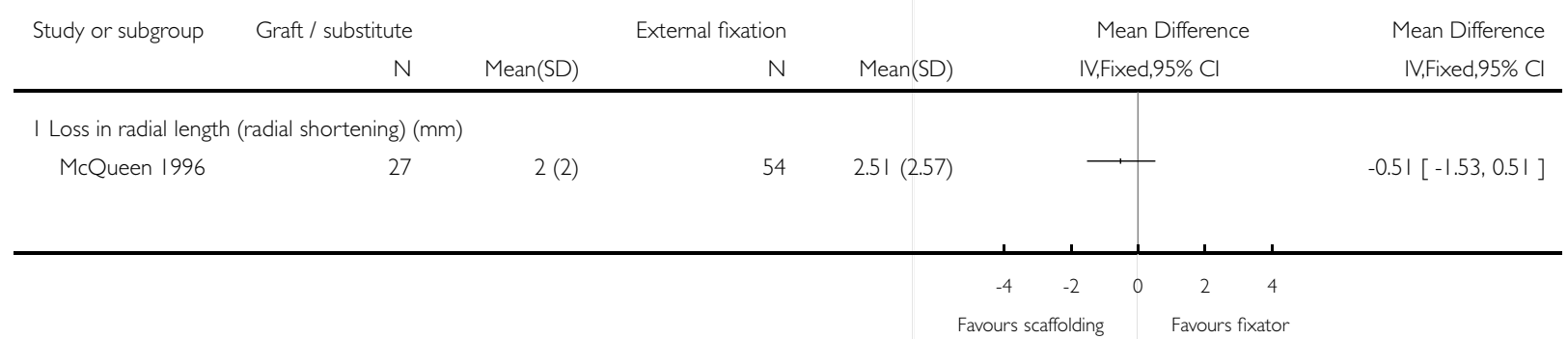


Analysis 5.9. Comparison 5 Bone scaffolding (graft/substitute) versus external fixation, Outcome 9 Anatomical measurements.

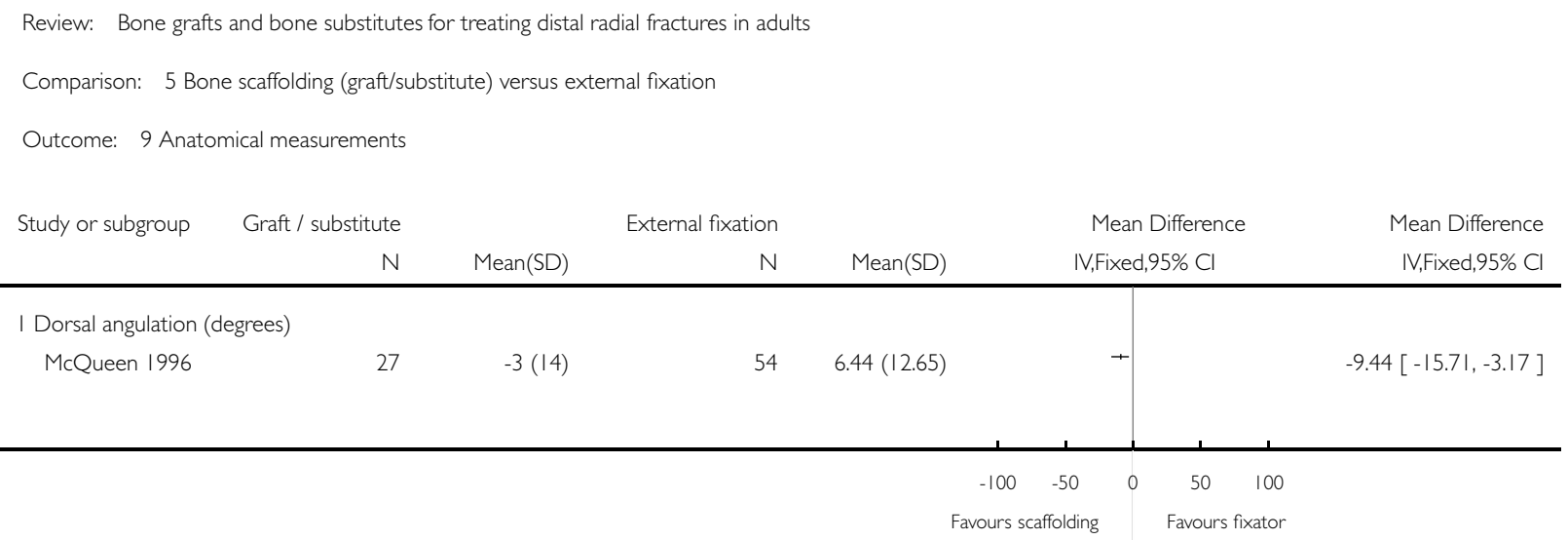

Analysis 5.10. Comparison 5 Bone scaffolding (graft/substitute) versus external fixation, Outcome 10 Long term redisplacement.

Review: Bone grafts and bone substitutes for treating distal radial fractures in adults

Comparison: 5 Bone scaffolding (graft/substitute) versus external fixation

Outcome: 10 Long term redisplacement

$\begin{array}{llll}\text { Study or subgroup } & \text { Graft / substitute } & \text { External fixation } & \text { Risk Ratio }\end{array}$

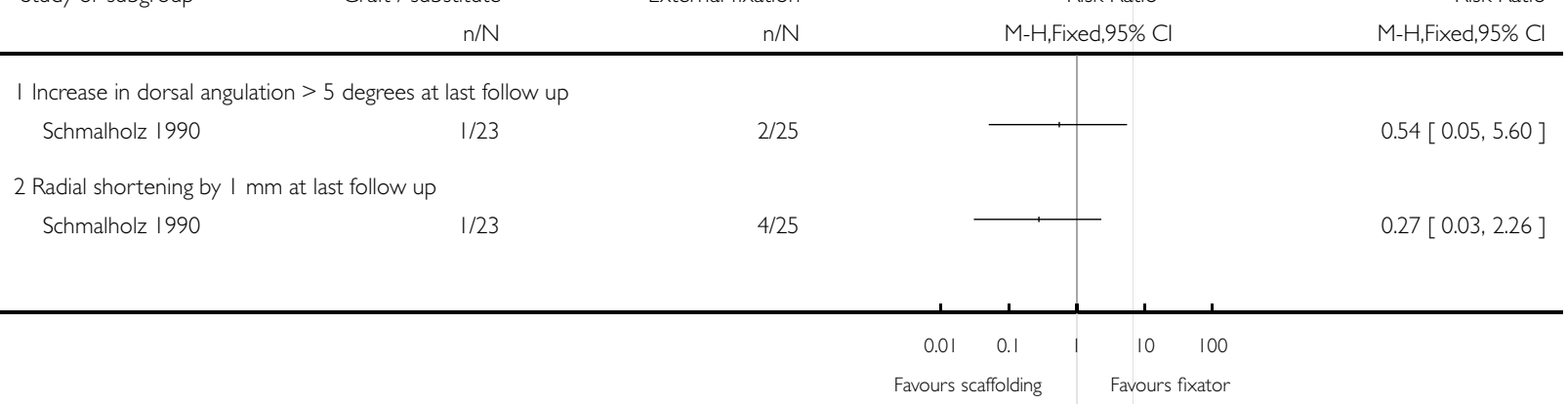


Analysis 5.I I. Comparison 5 Bone scaffolding (graft/substitute) versus external fixation, Outcome I I Deformity (cosmetic and structural).

\begin{tabular}{|c|c|c|c|c|}
\hline \multicolumn{5}{|c|}{ Comparison: 5 Bone scaffolding (graft/substitute) versus external fixation } \\
\hline \multicolumn{5}{|c|}{ Outcome: II Deformity (cosmetic and structural) } \\
\hline \multirow[t]{2}{*}{ Study or subgroup } & Graft / substitute & External fixation & \multirow{2}{*}{$\begin{array}{c}\text { Risk Ratio } \\
\text { M-H,Fixed,95\% Cl }\end{array}$} & Risk Ratio \\
\hline & $\mathrm{n} / \mathrm{N}$ & $n / N$ & & M-H,Fixed,95\% Cl \\
\hline \multicolumn{5}{|l|}{ I Carpal collapse } \\
\hline McQueen 1996 & $11 / 30$ & $25 / 60$ & $\rightarrow$ & $0.88[0.50,1.54]$ \\
\hline \multicolumn{5}{|l|}{2 Malunion } \\
\hline McQueen 1996 & $10 / 30$ & $24 / 60$ & & $0.83[0.46,1.51]$ \\
\hline \multicolumn{5}{|c|}{3 Dissatisfaction with wrist appearance for more than 3 months } \\
\hline Schmalholz 1990 & $0 / 23$ & $2 / 25$ & E & $0.22[0.01,4.29]$ \\
\hline
\end{tabular}

\section{Analysis 6.I. Comparison 6 Bone allograft versus autograft, Outcome I Moderate or severe restrictions in} everyday life.

Review: Bone grafts and bone substitutes for treating distal radial fractures in adults

Comparison: 6 Bone allograft versus autograft

Outcome: I Moderate or severe restrictions in everyday life

\begin{tabular}{|c|c|c|c|c|c|}
\hline \multirow[t]{2}{*}{ Study or subgroup } & Allograft & Autograft & \multicolumn{2}{|r|}{ Risk Ratio } & Risk Ratio \\
\hline & $\mathrm{n} / \mathrm{N}$ & $n / N$ & \multicolumn{2}{|r|}{ M-H,Fixed,95\% Cl } & M-H,Fixed,95\% Cl \\
\hline Rajan 2006 & $5 / 44$ & $6 / 46$ & & $\bar{z}$ & $0.87[0.29,2.65]$ \\
\hline
\end{tabular}


Analysis 6.2. Comparison 6 Bone allograft versus autograft, Outcome 2 Functional gradings.

Review: Bone grafts and bone substitutes for treating distal radial fractures in adults

Comparison: 6 Bone allograft versus autograft

Outcome: 2 Functional gradings

\begin{tabular}{|c|c|c|c|c|}
\hline \multirow{3}{*}{$\begin{array}{l}\text { Study or subgroup } \\
\text { I Not excellent }\end{array}$} & \multirow{2}{*}{$\begin{array}{r}\text { Allograft } \\
n / N\end{array}$} & \multirow{2}{*}{$\begin{array}{r}\text { Autograft } \\
\mathrm{n} / \mathrm{N}\end{array}$} & Risk Ratio & \multirow{2}{*}{$\begin{array}{r}\text { Risk Ratio } \\
\text { M-H,Fixed,95\% Cl}\end{array}$} \\
\hline & & & M-H,Fixed,95\% Cl & \\
\hline & & & & \\
\hline \multirow{2}{*}{$\begin{array}{c}\text { Rajan } 2006 \\
2 \text { Only fair (or poor) }\end{array}$} & $27 / 44$ & $22 / 46$ & 5 & $1.28[0.88,1.88]$ \\
\hline & & & & \\
\hline Rajan 2006 & $13 / 44$ & $12 / 46$ & - & $1.13[0.58,2.21]$ \\
\hline
\end{tabular}

Analysis 6.3. Comparison 6 Bone allograft versus autograft, Outcome 3 Grip strength (\% of normal hand).

Review: Bone grafts and bone substitutes for treating distal radial fractures in adults

Comparison: 6 Bone allograft versus autograft

Outcome: 3 Grip strength (\% of normal hand)

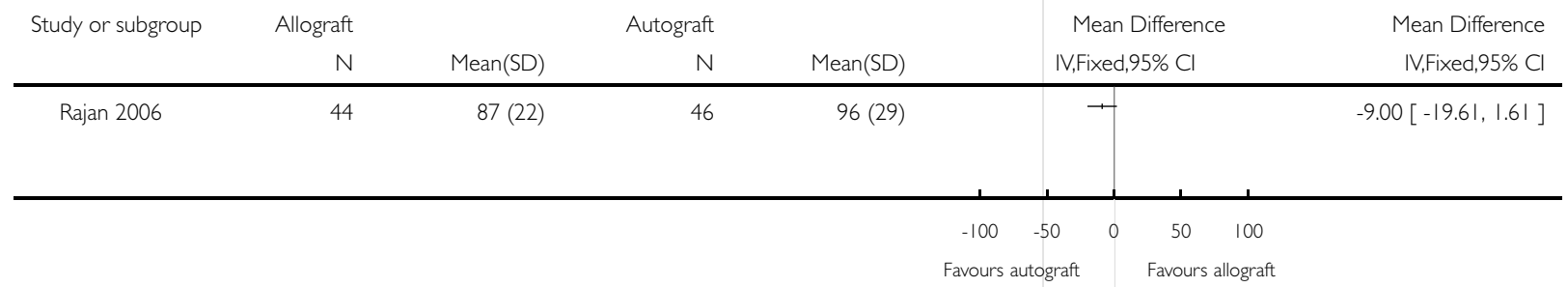


Analysis 6.4. Comparison 6 Bone allograft versus autograft, Outcome 4 Discomforting or worse wrist pain. Review: Bone grafts and bone substitutes for treating distal radial fractures in adults

Comparison: 6 Bone allograft versus autograft

Outcome: 4 Discomforting or worse wrist pain

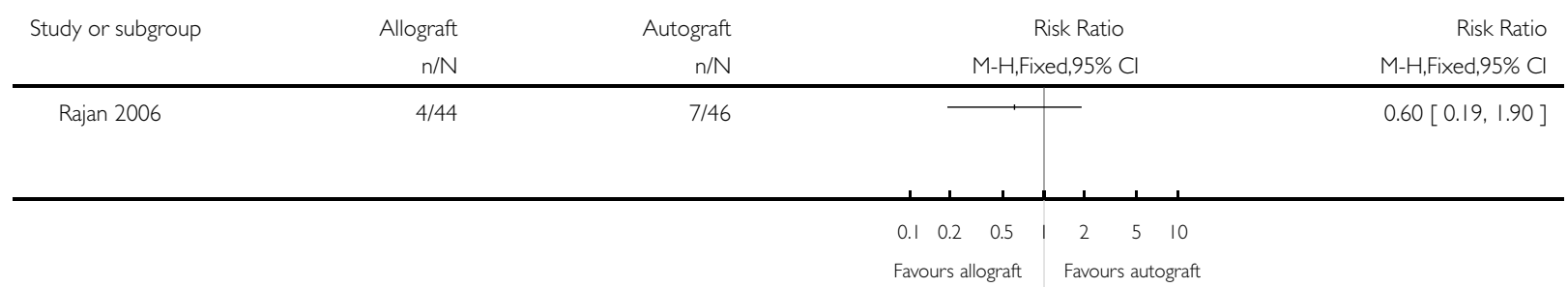

\section{Analysis 6.5. Comparison 6 Bone allograft versus autograft, Outcome 5 Range of movement (degrees).}

Review: Bone grafts and bone substitutes for treating distal radial fractures in adults

Comparison: 6 Bone allograft versus autograft

Outcome: 5 Range of movement (degrees)

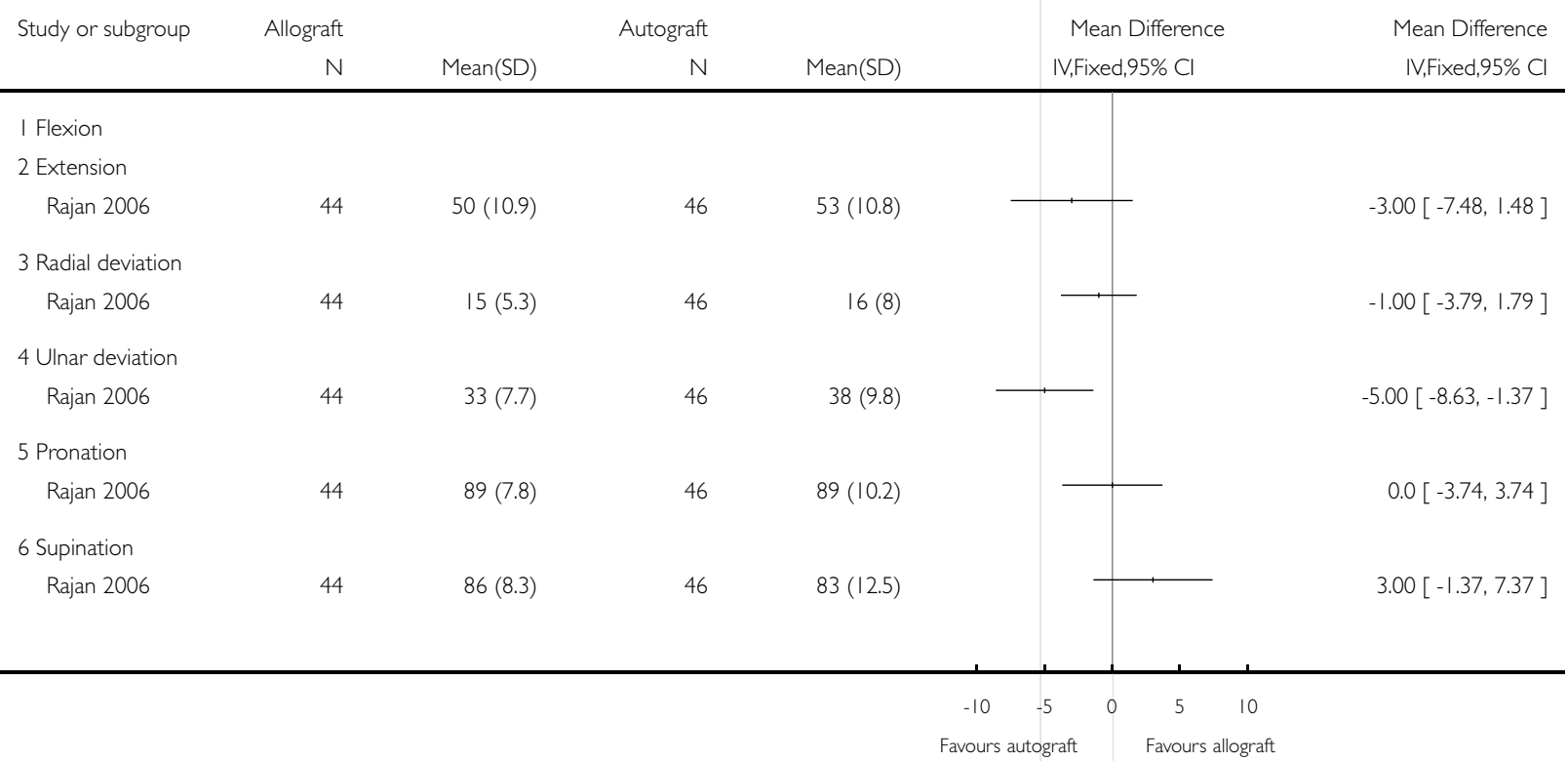




\section{Analysis 6.6. Comparison 6 Bone allograft versus autograft, Outcome 6 Complications.}

Review: Bone grafts and bone substitutes for treating distal radial fractures in adults

Comparison: 6 Bone allograft versus autograft

Outcome: 6 Complications

\begin{tabular}{|c|c|c|c|c|}
\hline Study or subgroup & $\begin{array}{r}\text { Allograft } \\
n / N\end{array}$ & $\begin{array}{r}\text { Autograft } \\
n / N\end{array}$ & $\begin{array}{c}\text { Risk Ratio } \\
\text { M-H,Fixed,95\% Cl }\end{array}$ & $\begin{array}{r}\text { Risk Ratio } \\
\text { M-H,Fixed,95\% Cl }\end{array}$ \\
\hline \multicolumn{5}{|c|}{ I Local or systematic immunogenic reactions } \\
\hline Rajan 2006 & $0 / 44$ & $0 / 46$ & & $0.0[0.0,0.0]$ \\
\hline \multicolumn{5}{|c|}{2 Plate removal because of limited wrist mobility } \\
\hline Rajan 2006 & $1 / 44$ & $3 / 46$ & + & $0.35[0.04,3.23]$ \\
\hline \multicolumn{5}{|c|}{3 latrogenic injury (donor-site: tear off of the anterior superior iliac spine) } \\
\hline Rajan 2006 & $0 / 44$ & $1 / 46$ & $\overline{-}$ & $0.35[0.01,8.33]$ \\
\hline \multicolumn{5}{|c|}{4 Short-term ( $<2$ weeks) post-operative pain (from iliac-crest harvesting) } \\
\hline Rajan 2006 & $0 / 44$ & $23 / 46$ & & $0.02[0.00,0.36]$ \\
\hline \multicolumn{5}{|c|}{5 Haematoma (donor site) } \\
\hline Rajan 2006 & $0 / 44$ & $8 / 46$ & & $0.06[0.00,1.03]$ \\
\hline \multicolumn{5}{|c|}{6 Discomforting paraesthesias (lower limb) at I year } \\
\hline Rajan 2006 & $0 / 44$ & $6 / 46$ & & $0.08[0.00,1.39]$ \\
\hline \multicolumn{5}{|c|}{7 Continuing pain (mild or discomforting) from donor site at I year } \\
\hline Rajan 2006 & $0 / 44$ & $13 / 46$ & & $0.04[0.00,0.63]$ \\
\hline
\end{tabular}

Analysis 6.7. Comparison 6 Bone allograft versus autograft, Outcome 7 Dissatisfaction (only poor or fair rating of treatment outcome).

Review: Bone grafts and bone substitutes for treating distal radial fractures in adults

Comparison: 6 Bone allograft versus autograft

Outcome: 7 Dissatisfaction (only poor or fair rating of treatment outcome)

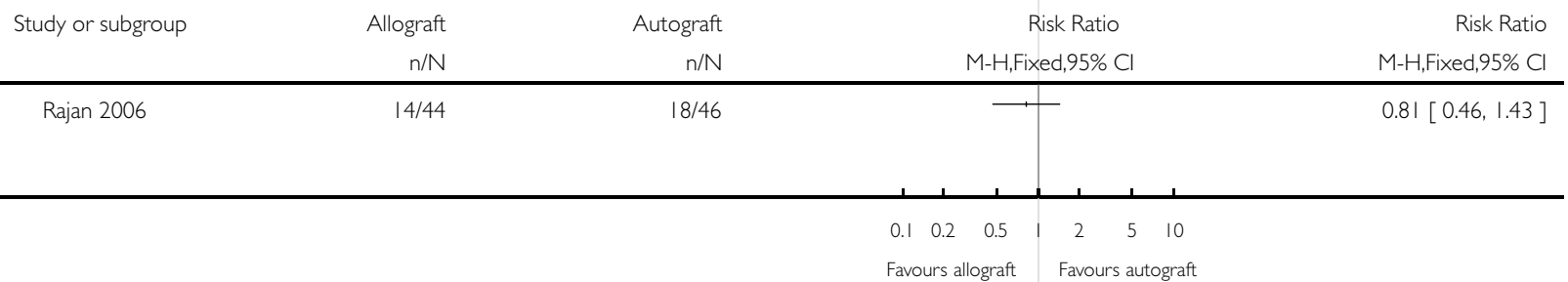


Analysis 6.8. Comparison 6 Bone allograft versus autograft, Outcome 8 Anatomical measurements (I year).

Review: Bone grafts and bone substitutes for treating distal radial fractures in adults

Comparison: 6 Bone allograft versus autograft

Outcome: 8 Anatomical measurements (I year)

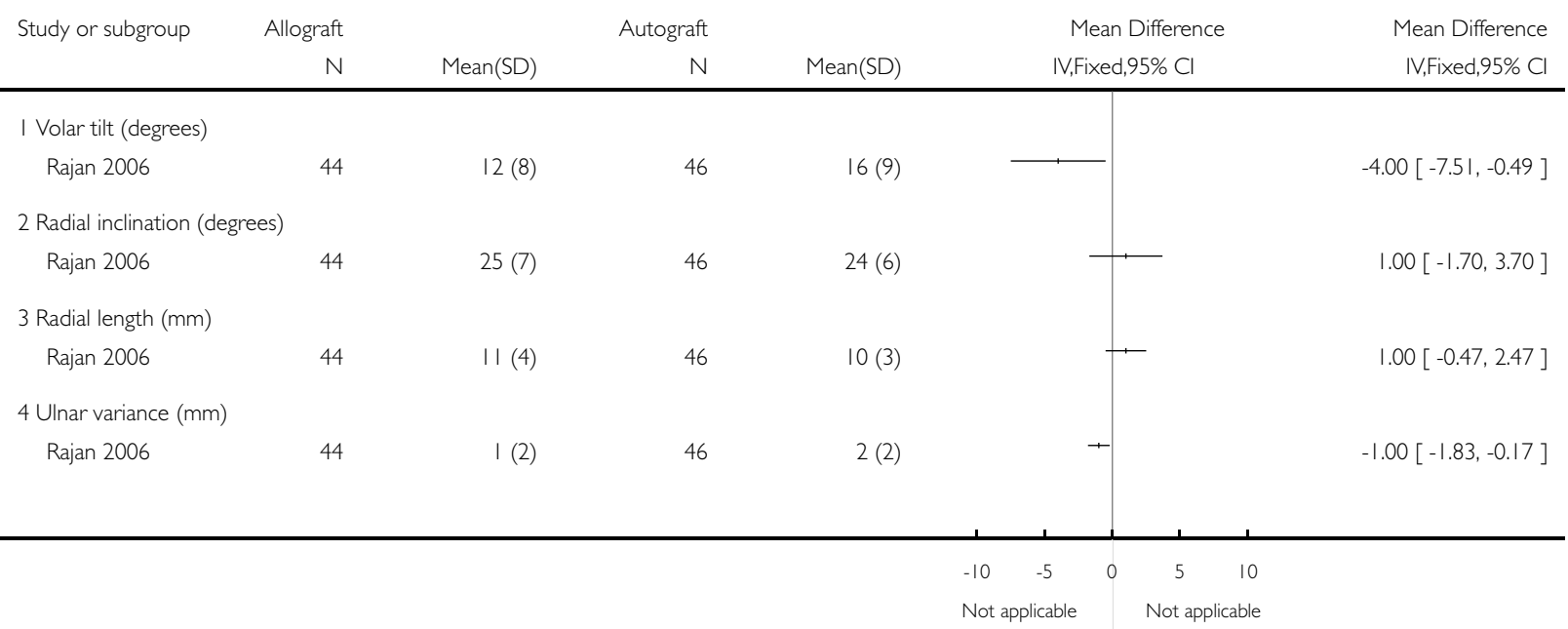

Analysis 6.9. Comparison 6 Bone allograft versus autograft, Outcome 9 Anatomical outcomes.

Review: Bone grafts and bone substitutes for treating distal radial fractures in adults

Comparison: 6 Bone allograft versus autograft

Outcome: 9 Anatomical outcomes

\begin{tabular}{|c|c|c|c|c|}
\hline \multirow[t]{2}{*}{ Study or subgroup } & Allograft & Autograft & \multirow{2}{*}{$\begin{array}{c}\text { Risk Ratio } \\
\text { M-H,Fixed,95\% Cl }\end{array}$} & \multirow{2}{*}{$\begin{array}{r}\text { Risk Ratio } \\
\text { M-H,Fixed,95\% Cl }\end{array}$} \\
\hline & $\mathrm{n} / \mathrm{N}$ & $\mathrm{n} / \mathrm{N}$ & & \\
\hline \multicolumn{5}{|l|}{ I Dorsal tilt } \\
\hline Rajan 2006 & $2 / 44$ & $0 / 46$ & & $5.22[0.26,105.81]$ \\
\hline \multicolumn{5}{|c|}{2 Ulnar variance $>5 \mathrm{~mm}$} \\
\hline Rajan 2006 & $3 / 44$ & $2 / 46$ & -1, & $1.57[0.28,8.94]$ \\
\hline \multicolumn{5}{|c|}{3 Articular incongruence (all $<2 \mathrm{~mm}$ ) } \\
\hline Rajan 2006 & $9 / 44$ & $11 / 46$ & - & $0.86[0.39,1.86]$ \\
\hline
\end{tabular}

$0.0010 .010 .1 \quad 1 \quad 10 \quad 100 \quad 1000$

Favours allograft Favours autograft 
Analysis 6.10. Comparison 6 Bone allograft versus autograft, Outcome 10 Length of operating (minutes).

Review: Bone grafts and bone substitutes for treating distal radial fractures in adults

Comparison: 6 Bone allograft versus autograft

Outcome: 10 Length of operating (minutes)

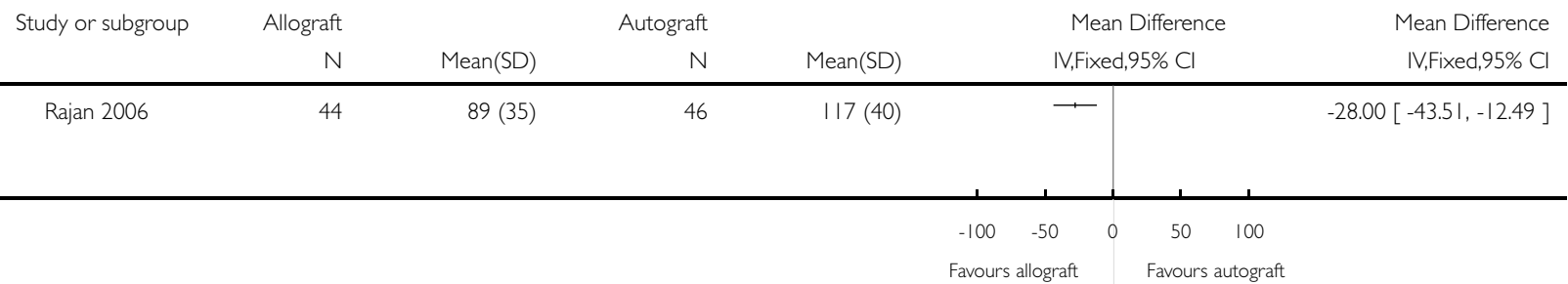

Analysis 6.I I. Comparison 6 Bone allograft versus autograft, Outcome I I Length of hospital stay (days).

Review: Bone grafts and bone substitutes for treating distal radial fractures in adults

Comparison: 6 Bone allograft versus autograft

Outcome: I Length of hospital stay (days)

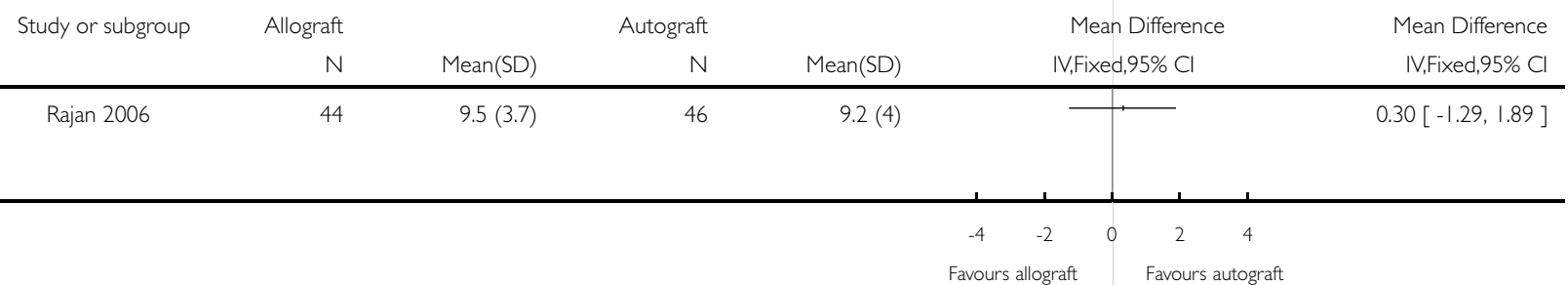

A P P E N D I C E S

Appendix I. Search strategy for The Cochrane Library (Wiley InterScience)

The Cochrane Library

\#1 MeSH descriptor Radius Fractures explode all trees in MeSH products

\#2 MeSH descriptor Wrist Injuries explode all trees in MeSH products

\#3 (\#1 OR \#2)

\#4 ((distal near radius) or (distal near radial)) in Title, Abstract or Keywords in all products 


\section{(Continued)}

\#5 (colles or smith or smiths) in Title, Abstract or Keywords in all products

$\# 6$ wrist* in Title, Abstract or Keywords in all products

\#7 (\#4 OR \#5 OR \#6)

$\# 8$ fractur* in Title, Abstract or Keywords in all products

\#9 (\#7 AND \#8)

\#10 (\#3 OR \#9) 
Appendix 2. Search strategies for CINAHL and EMBASE (OVID-WEB)

\begin{tabular}{|c|c|}
\hline CINAHL & EMBASE \\
\hline 1. Radius Fractures/ & 1. $((($ distal adj 3 (radius or radial $))$ or wrist or colles $\$ 2$ or smith $\$ 2)$ \\
\hline 2. Wrist Injuries/ & adj3 fracture $\$$ ).tw. \\
\hline 3. or/1-2 & 2. Colles Fracture/ or Radius Fracture/ or Wrist Fracture/ or Wrist \\
\hline 4. $((($ distal adj3 (radius or radial) $)$ or wrist or colles or smith $\$ 2)$ & Injury/ \\
\hline adj3 fracture $\$$ ).ti,ab. & 3. or/1-2 \\
\hline 5. or/3-4 & 4. exp Randomized Controlled Trial/ \\
\hline 6. exp Clinical Trials/ & 5. exp Double Blind Procedure/ \\
\hline 7. exp Evaluation Research/ & 6. exp Single Blind Procedure/ \\
\hline 8. exp Comparative Studies/ & 7. exp Crossover Procedure/ \\
\hline 9. $\exp$ Crossover Design/ & 8. or/4-8 \\
\hline $\begin{array}{l}\text { 10. clinical trial.pt. } \\
\text { 11. or/6-10 }\end{array}$ & $\begin{array}{l}\text { 9. ((clinical or controlled or comparative or placebo or prospec- } \\
\text { tive } \$ \text { or randomi\#ed)adj } 3 \text { (trial or study)).tw. }\end{array}$ \\
\hline $\begin{array}{l}\text { 12. ((clinical or controlled or comparative or placebo or prospec- } \\
\text { tive or randomi\#ed)adj3 (trial or study)).tw. }\end{array}$ & $\begin{array}{l}\text { 10. (random } \$ \text { adj7 (allocat } \$ \text { or allot } \$ \text { or assign } \$ \text { or basis } \$ \text { or divid } \$ \\
\text { or order } \$) \text { ).tw. }\end{array}$ \\
\hline $\begin{array}{l}\text { 13. (random } \$ \text { adj7 (allocat } \$ \text { or allot } \$ \text { or assign } \$ \text { or basis } \$ \text { or divid } \$ \\
\text { or order } \$) \text { ).tw. }\end{array}$ & $\begin{array}{l}\text { 11. ((singl } \$ \text { or doubl } \$ \text { or trebl } \$ \text { or tripl } \$) \text { adj7 (blind } \$ \text { or mask } \$ \text { ) } \\
\text { ).tw. }\end{array}$ \\
\hline 14. ( (singl\$ or doubl\$ or trebl\$ or tripl\$) adj7 (blind $\$$ or mask $\$$ ) & 12. (cross?over\$ or (cross adj1 over\$)).tw. \\
\hline ).tw. & 13. ( $($ allocat $\$$ or allot $\$$ or assign $\$$ or divid $\$)$ adj 3 (condition $\$$ or \\
\hline 15. (cross?over $\$$ or (cross adj1 over $\$))$.tw. & experiment $\$$ or intervention $\$$ or treatment $\$$ or therap $\$$ or con- \\
\hline 16. ( (allocat $\$$ or allot $\$$ or assign $\$$ or $\operatorname{divid} \$$ ) adj3 (condition $\$$ or & trol\$ or group $\$)) . t w$ \\
\hline experiment $\$$ or intervention $\$$ or treatment $\$$ or therap $\$$ or con- & 14. or/9-13 \\
\hline trol\$ or group\$)).tw. & 15. or $/ 8,14$ \\
\hline 17. or/ $12-16$ & 16. Animal/ not Human/ \\
\hline 18. or/ 11,17 & 17. 15 not 16 \\
\hline 19. and $/ 5,18$ & 18. and $/ 3,17$ \\
\hline
\end{tabular}

\section{WHAT'S NEW}

Last assessed as up-to-date: 6 June 2007.

8 May 2008 Amended Converted to new review format. 


\section{H I S T O R Y}

Protocol first published: Issue 4, 2007

Review first published: Issue 2, 2008

\section{CONTRIBUTIONSOFAUTHORS}

This review was initiated by Helen Handoll $(\mathrm{HH})$ who prepared the first draft of the protocol. This was critically reviewed by the other author, Adam Watts (AW). HH searched for trials and contacted trial authors. Both authors performed study selection of trials that had not been included in a previous review covering all surgical interventions. HH repeated her review of the other included trials that had been quality assessed previously by $\mathrm{HH}$ and Rajan Madhok (see Acknowledgements). HH completed the first draft of the review in RevMan. All versions were scrutinised by AW. Helen Handoll is the guarantor of the review.

\section{DECLARATIONS OF INTEREST}

None known.

\section{SOURCES OF SUPPORT}

\section{Internal sources}

- University of Teesside, Middlesbrough, UK.

\section{External sources}

- No sources of support supplied

\section{NOTES}

Some of the wording in each of several sections of this review (in particular: Synopsis, Background, Methods, Discussion and Implications) is taken either entirely or in only a slightly modified form from related reviews: "Percutaneous pinning for distal radial fractures in adults", "External fixation versus conservative treatment for distal radial fractures in adults" and "Different methods of external fixation for treating distal radial fractures in adults". This has been done to make the review self-contained and to ensure consistency between related reviews without requiring unnecessary cross-referrence by readers.

\section{N D EX TERMS}




\section{Medical Subject Headings (MeSH)}

${ }^{*}$ Bone Transplantation; Bone Substitutes [ ${ }^{*}$ therapeutic use]; Fracture Fixation [* methods]; Radius Fractures [*surgery]; Randomized Controlled Trials as Topic; Wrist Injuries [surgery]

\section{MeSH check words}

Adult; Humans 